\title{
Age Relations Between Soils and Geology in the Coastal Plain of Maryland and Virginia
}

\section{U.S. GEOLOGICAL SURVEY BULLETIN 1589-A}

Prepared in cooperation with the U.S. Department of Agriculture, Soil Conservation Service

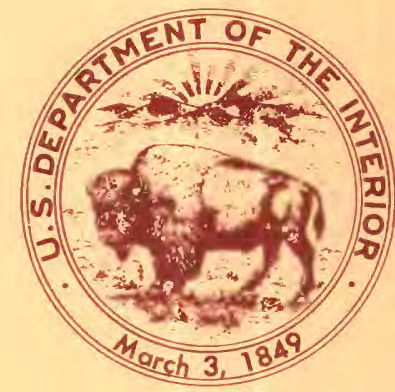



Chapter A

\section{Age Relations Between Soils and Geology in the Coastal Plain of Maryland and Virginia}

By H.W. MARKEWICH, M.J. PAVICH, M.J. MAUSBACH, R.L. HALL, R.G. JOHNSON, and P.P. HEARN

Prepared in cooperation with the U.S. Department of Agriculture, Soil Conservation Service

Soils developed from dated parent material ranging in age from 30,000 to about 1.0 ? million years have been characterized from field descriptions and laboratory analyses; age-related trends are documented from field and laboratory data

\section{U.S. GEOLOGICAL SURVEY BULLETIN 1589}

PEDOLOGIC STUDIES IN THE EASTERN UNITED STATES:

RELATIONS TO GEOLOGY 


\title{
DEPARTMENT OF THE INTERIOR DONALD PAUL HODEL, Secretary
}

\author{
U.S. GEOLOGICAL SURVEY \\ Dallas L. Peck, Director
}

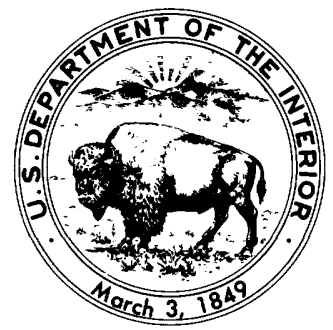

For sale by the Books and Open-File Reports Section, U.S. Geological Survey, Federal Center, Box 25425, Denver, CO 80225

The use of brand names is for descriptive purposes only and does not imply endorsement by the U.S. Geological Survey.

\section{Library of Congress Cataloging in Publication Data}

Main entry under title:

Age relations between soils and geology in the Coastal Plain of Maryland and Virginia.

(U.S. Geological Survey bulletin: 1589-A)

(Pedologic studies in the Eastern United States, relations to geology)

Supt. of Docs. no.: I 19.3:1589-A

1. Soils-Eastern Shore (Md. and Va.)-Age. 2. Soils-Virginia-Rappahannock River Region-Age. 3. Soil formation-Eastern Shore (Md. and Va.) 4. Soil formation-Rappahannock River. 5. Geology-Eastern Shore (Md. and Va.) 6. Geology-Virginia-Rappahannock River Region. 7. Geology, Stratigraphic-Recent. I. Markewich, Helaine W. II. Series. III. Series: U.S. Geological Survey bulletin; 1589-A.

QE75.B9 no. 1589-A $557.3 \mathrm{~s}$

[S599.M3]

85-600233 


\section{PREFACE}

Some geologic investigations of Quaternary deposits, especially in the conterminous United States, have attempted to use relative degrees of weathering and soil formation to establish chronosequences of glacial and (or) fluvial landforms. Most studies have been in the glacial terrane of the midcontinent and the Western United States. Few such studies have been conducted in the Eastern United States, especially in the unglaciated Middle Atlantic and Southeastern States.

From 1979 to 1984 , the U.S. Geological Survey and the U.S. Department of Agriculture's Soil Conservation Service conducted cooperative regional studies of the relations between soils and geology in the Middle Atlantic and Southeastern States. The primary goal of these studies was to determine if soil properties could be used to estimate ages of associated landforms. Coral, wood fragments, and peat were sampled from constructional landforms of fluvial and marine origin in order to estimate ages by isotopic analyses; these ages were then related to regional biostratigraphic and lithostratigraphic correlations. Specific site investigations were conducted on Pliocene to Holocene marine and fluvial terraces in the Atlantic and eastern Gulf Coastal Plains and on constructional landforms and residual soils in the Appalachian Piedmont. Soils on granite, schist, and quartzite parent rocks of the Appalachian Piedmont were sampled to test the use of soil properties as indicators of soil age. Each chapter of this bulletin series examines the relation of soils to geology in a specific geographic area.

The cooperative study involved research scientists from both agencies and field personnel from State offices of the Soil Conservation Service. Responsibility for sample analysis was divided between the Department of Agriculture's National Soil Survey Laboratory in Lincoln, Nebr., and the U.S. Geological Survey in Reston, Va. This report was prepared by scientists from both agencies who participated in specific site investigations or in studies of pedogenic processes. 



\section{CONTENTS}

Preface III

Abstract 1

Introduction 1

Physiographic and geologic setting 2

Climate 2

Physiography $\mathbf{2}$

Geology 2

Field and laboratory methods 4

Results and discussion $\mathbf{5}$

Data presentation $\mathbf{5}$

Classification of soils

Physical characteristics $\mathbf{8}$

Chemical characteristics $\mathbf{1 0}$

Mineralogy of the $<2$ micron fraction $\mathbf{1 0}$

The loess problem 12

Age relations 15

Conclusions 16

Acknowledgments 17

References cited 17

\section{FIGURES}

1. Map of the Coastal Plain of Virginia, Maryland, and Delaware 3

2. Cross sections showing:

$A$, Geology across the southern Delmarva Peninsula 4

$B$, Geology at soil sampling sites 6,7 , and 8 on terraces of the Rappahannock River $\mathbf{5}$

3-10. Graphs showing:

3. Texture (on a clay-free basis) and weight percent of the $<2$ micron fraction 6

4. Solum thickness of soil profiles plotted against age 9

5. Thickness of argillic $(\mathrm{Bt})$ horizons plotted against age 9

6. Clay mass of solum plotted against age 9

7. Hue of argillic $(\mathrm{Bt})$ horizons plotted against age 9

8. $\mathrm{Fe}_{2} \mathrm{O}_{3}+\mathrm{Al}_{2} \mathrm{O}_{3} / \mathrm{SiO}_{2}$ of sola plotted against age $\mathbf{1 0}$

9. Weight percent $\mathrm{TiO}_{2}$ plotted against age $\mathbf{1 1}$

10. Weight percent $\mathrm{MnO}$ plotted against age $\mathbf{1 1}$

11-18. X-ray diffraction patterns for:
11. Site $1 \mathbf{1 2}$
12. Site $2 \mathbf{1 2}$
13. Site $3 \mathbf{1 3}$
14. Site $4 \mathbf{1 3}$
15. Site $5 \mathbf{1 4}$
16. Site $6 \quad 14$
17. Site $7 \mathbf{1 5}$
18. Site $8 \quad \mathbf{1 5}$ 
19-20. Graphs showing:

19. Ratio of peak heights of $14.2 \mathrm{~A}+4.85 \mathrm{~A} / 7.2 \mathrm{~A}+4.5 \mathrm{~A}$ clay peaks plotted against [horizon depth $\times$ percent clay per horizon] for sites $3,5,7$, and 816

20. Variation through time in values of clay, organic carbon, and carbonate in soils 17

\section{TABLES}

1. Analytical methods and units of expression for analyses conducted at the Soil Conservation Service, National Soil Survey Laboratory, Lincoln,

Nebraska 20

2. Soil horizons at site 1 :

$A$, Description of physical characteristics $\mathbf{2 1}$

$B$, Textural analyses $\mathbf{2 1}$

$C$, Weight percent of oxides $\mathbf{2 2}$

$D$, Analyses of extractable $\mathrm{Fe}, \mathrm{Al}$, oxalates, and $\mathrm{pH} \mathbf{2 2}$

3. Soil horizons at site 2:

$A$, Description of physical characteristics $\mathbf{2 2}$

$B$, Textural analyses $\mathbf{2 3}$

$C$, Weight percent of oxides $\mathbf{2 3}$

$D$, Analyses of extractable $\mathrm{Fe}, \mathrm{Al}$, and $\mathrm{Mn}$, oxalates, ratio clay, and bulk density $\mathbf{2 3}$

$E$, Analyses of extractable bases, extractable $\mathrm{Al}$, cation exchange capacity (CEC), Al saturation, and $\mathrm{pH} \mathbf{2 4}$

4. Soil horizons at site 3 :

$A$, Description of physical characteristics $\mathbf{2 4}$

$B$, Textural analyses $\mathbf{2 4}$

$C$, Weight percent of oxides $\mathbf{2 5}$

$D$, Analyses of extractable $\mathrm{Fe}, \mathrm{Al}$, and $\mathrm{Mn}$, oxalates, ratio clay, and bulk density 25

$E$, Analyses of extractable bases, extractable $\mathrm{Al}$, cation exchange capacity (CEC), Al saturation, and $\mathrm{pH} \mathbf{2 5}$

5. Soil horizons at site 4 :

$A$, Description of physical characteristics $\mathbf{2 6}$

$B$, Textural analyses $\mathbf{2 6}$

$C$, Weight percent of oxides $\mathbf{2 6}$

$D$, Analyses of extractable $\mathrm{Fe}, \mathrm{Al}$, and $\mathrm{Mn}$, oxalates, ratio clay, and bulk density $\mathbf{2 7}$

$E$, Analyses of extractable bases, extractable $\mathrm{Al}$, cation exchange capacity (CEC), Al saturation, and $\mathrm{pH} \mathbf{2 7}$

6. Soil horizons at site 5:

$A$, Description of physical characteristics 28

$B$, Textural analyses $\mathbf{2 8}$

$C$, Weight percent of oxides $\mathbf{2 8}$

$D$, Analyses of extractable $\mathrm{Fe}, \mathrm{Al}$, and $\mathrm{Mn}$, oxalates, ratio clay, and bulk density 29

$E$, Analyses of extractable bases, extractable $\mathrm{Al}$, cation exchange capacity (CEC), $\mathrm{Al}$ saturation, and $\mathrm{pH}$ 
7. Soil horizons at site 6 :

$A$, Description of physical characteristics

$B$, Textural analyses $\mathbf{3 0}$

$C$, Weight percent of oxides $\mathbf{3 0}$

$D$, Analyses of extractable $\mathrm{Fe}, \mathrm{Al}$, and $\mathrm{Mn}$, oxalates, ratio clay, and bulk density $\mathbf{3 0}$

$E$, Analyses of extractable bases, extractable $\mathrm{Al}$, cation exchange capacity (CEC), $\mathrm{Al}$ saturation, and $\mathrm{pH} \mathbf{3 1}$

8. Soil horizons at site 7 :

$A$, Description of physical characteristics $\mathbf{3 1}$

$B$, Textural analyses $\mathbf{3 1}$

$C$, Weight percent of oxides 32

$D$, Analyses of extractable $\mathrm{Fe}, \mathrm{Al}$, and $\mathrm{Mn}$, oxalates, ratio clay, and bulk density 32

$E$, Analyses of extractable bases, extractable $\mathrm{Al}$, cation exchange capacity (CEC), and $\mathrm{pH} 32$

9. Soil horizons at site 8:

$A$, Description of physical characteristics $\mathbf{3 3}$

$B$, Textural analyses $\mathbf{3 3}$

$C$, Weight percent of oxides $\mathbf{3 3}$

$D$, Analyses of extractable $\mathrm{Fe}, \mathrm{Al}$, and $\mathrm{Mn}$, oxalates, ratio clay, and bulk density 34

$E$, Analyses of extractable bases, cation exchange capacity (CEC), and $\mathrm{pH} \mathbf{3 4}$ 



\title{
Age Relations Between Soils and Geology in the Coastal Plain of Maryland and Virginia
}

\author{
By H.W. Markewich, M.J. Pavich, M.J. Mausbach, ${ }^{1}$ R.L. Hall, ${ }^{2}$ R.G. Johnson, and P.P. Hearn
}

\section{Abstract}

Soils and their related surfaces on marine and fluvial deposits of the Maryland and Virginia eastern shore and on similar deposits along the lower reaches of the Rappahannock River provide the basis for comparing soil development to soil age. In this region, soils, if developed in similar parent material on uneroded positions in the landscape, can be used to form a chronosequence of landforms based on relative ages. In a few areas, where a soil is developed in parent material that has been dated by isotopic analysis, a maximum age can be determined for the soil and the surface upon which it has developed. Solum thickness, thickness of the argillic horizon, color, and clay mass $\left(\mathrm{g} / \mathrm{cm}^{2}\right.$ summed through solum), as well as the degree of $\mathrm{Al}$ and Fe enrichment, indicate that significant differences exist among soils of early Pleistocene ( $>1.0$ ? m.y.) to late Pleistocene $(30,000$ years) age. In this study soils associated with a specific constructional land surface are assumed to be only slightly younger than the parent material associated with the surface, unless pedogenic data indicate that the surface has been eroded and (or) the soil truncated.

Soils that are developed in 25,000- to 35,000-year-old parent material have solum thicknesses of 60 to $100 \mathrm{~cm}, \mathrm{~B}$ horizons that are 20 to $30 \mathrm{~cm}$ thick, clay mass values $<10$ $\mathrm{g} / \mathrm{cm}^{2}$, and $\mathrm{Al}+\mathrm{Fe} / \mathrm{Si}$ values $<10.0$. Soils developed on 60,000to 200,000-year-old parent material have sola that range in thickness from 100 to $200 \mathrm{~cm}$, Bt horizons that range in thickness from 90 to $175 \mathrm{~cm}$, clay mass values from 23 to $35 \mathrm{~g} / \mathrm{cm}^{2}$, and $\mathrm{Al}+\mathrm{Fe} / \mathrm{Si}$ values from 13.0 to 19.0. Soils that are developed on primary surfaces considered to be about 500,000? years in age have solum thicknesses greater than $160 \mathrm{~cm}$, Bt horizon thicknesses that are greater than $130 \mathrm{~cm}$, clay mass values $>80$ $\mathrm{g} / \mathrm{cm}^{2}$, and $\mathrm{Al}+\mathrm{Fe} / \mathrm{Si}$ values greater than 35.0. Soils developed on materials estimated to be about 1.0 ? m.y. in age have solum thicknesses $>250 \mathrm{~cm}$, Bt horizon thicknesses $>220 \mathrm{~cm}$, clay mass values $>140 \mathrm{~g} / \mathrm{cm}^{2}$, and $\mathrm{Al}+\mathrm{Fe} / \mathrm{Si}$ values of 25.0 to 27.0 , somewhat less than the value of 35.0 for soils developed on

${ }^{1}$ U.S. Department of Agriculture, Soil Conservation Service, National Soil Survey Laboratory, Lincoln, NE 68508.

${ }^{2} U$.S. Department of Agriculture, Soil Conservation Service, Easton, MD 21601.
500,000 -year-old parent material. Soil color varies from 7.5YR $5 / 8$ for the Bt horizon developed in 25,000- to 35,000-year-old parent material to $2.5 Y R 4 / 6$ for Bt horizons developed in the 1.0?-m.y.-old parent material. The percent sand of total solids decreases with increasing age of soil. Soil structure in the argillic horizon changes with this change in texture. Medium subangular blocky is the dominant structure of the 60,000 - to 200,000 -year-old soils with $>50$ percent sand (sandy loam and loam textures); medium and coarse prismatic is the structure of the 500,000?-year- and 1.0?m.y.-old soils with $<40$ percent sand (silty loam, silty clay loam, and clay textures).

Soils developed on 60,000- to 500,000-year-old parent material are similar and are difficult to distinguish from each other. The $\mathrm{Al}+\mathrm{Fe} / \mathrm{Si}$ value may be the most useful parameter in differentiating these soils, but it does not appear to be useful in differentiating soils $>500,000$ ? years in age. Clay mass, thickness of argillic horizon, and hue may be better indicators of age for early Pleistocene soils.

Nonexpandable hydroxy-interlayered dioctahedral vermiculite (HIV) increases relative to kaolinite and mica with increasing age and greater weathering in soils $<500,000$ ? years in age. Data suggest that kaolinite may increase relative to HIV in soils $>1.0$ ? m.y. in age.

\section{INTRODUCTION}

Despite the large volume of literature on Quaternary soils of North America, relatively little information is available on soils developed in Pliocene and Quaternary marine and fluvial deposits in the mid-Atlantic Coastal Plain (Daniels and Gamble, 1978; Daniels and others, 1978; Foss and others, 1978; Douglas, 1977). For this region, unlike the central plain states and portions of the west coast states (Ruhe, 1969; Follmer, 1978), no systematic study exists that relates properties of soils either to the mineralogy or to the age of the parent materials. This may be attributed in part to the lack of detailed geologic maps of Pliocene and Pleistocene units in this part of the Coastal Plain. Over the 
past 10 years, however, detailed geologic information for specific areas has become available. As a result, the U.S. Geological Survey (USGS) and Soil Conservation Service (SCS) undertook a cooperative study to determine whether soils and associated weathering profiles, developed in Quaternary marine and fluvial sediments in the Chesapeake Bay area, could be used as indicators of relative and (or) absolute age of the surfaces and (or) sediments. The purpose of this paper is to present data that suggest correlation between soil development and the age of the underlying material. Specifically we present (1) detailed chemical and physical data for eight soils in the study area; (2) relation of each soil to its position in the landscape and to the known or inferred age of its parent material; (3) physical and chemical characteristics most useful for pedologic comparison; and (4) for the Maryland-Virginia Coastal Plain, a range for each significant characteristic so that an estimate of the numerical age can be ascertained for the land surface.

\section{PHYSIOGRAPHIC AND GEOLOGIC SETTING}

\section{Climate}

The Delmarva Peninsula and the lower Rappahannock River area lie between $75^{\circ} 36^{\prime} \mathrm{W}$. and $77^{\circ} 21^{\prime} \mathrm{W}$. long and $36^{\circ} 54^{\prime} \mathrm{N}$. and $39^{\circ} 40^{\prime} \mathrm{N}$. lat (fig. 1). The present climate is humid continental, with well-defined seasons and mild winters. The maximum mean monthly temperature of the area studied $(1892$ to 1981$)$ is $28.9^{\circ} \mathrm{C}$ in July and $2.0^{\circ} \mathrm{C}$ in January. The mean annual temperature over the period is $15.2^{\circ} \mathrm{C}$. The mid-Atlantic Coast Plain climate is commonly less severe than that of regions of the continental interior at the same latitude, due to such modifying factors as proximity to the Gulf Stream, Atlantic Ocean, and the Appalachian Mountains. The average annual precipitation is $1,118 \mathrm{~mm}$. Precipitation is distributed fairly uniformly through the year, but parts of the area undergo annual drought and flood. Paleontologic evidence suggests that the present climate is similar to that of interglacial periods during the past 3 m.y.

\section{Physiography}

The part of the Delaware, Maryland, and Virginia Coastal Plain east of the Chesapeake Bay is called the Delmarva Peninsula. The peninsula, a coastal lowland that separates the Chesapeake Bay from the Atlantic Ocean (fig. 1), is $50 \mathrm{~km}$ across at its widest point and narrows to the north and the south. It slopes gently from the highest point in the north, $31 \mathrm{~m}$ near Elk Neck, to $12 \mathrm{~m}$ near Cape Charles. Streams are not deeply incised, but progressively older surfaces are more modified by erosion. Although many of the streams are free flowing in their upper reaches, their lower reaches are tidal.

The Rappahannock River, Virginia, drains the Piedmont and Coastal Plain west of Chesapeake Bay and south of the Potomac River (fig. 1). Cut and fill fluvial and estuarine terraces flank the lower reaches of the Rappahannock River where it flows through the Coastal Plain. Terrace morphology changes with terrace age (Colman, 1983) and progressively older terraces show increasing drainage density and decreasing preservation of original depositional area.

\section{Geology}

Sediments of Quaternary age, chiefly near-shore marine and estuarine beds, constitute the surface deposits of the Delmarva Peninsula. Recent investigations on the Delmarva Peninsula indicate that lower Pleistocene sediments are not preserved (Owens and Denny, 1979; Mixon and others, 1982). Mixon (1985) indicated that the oldest Pleistocene unit is the 200,000-year-old Accomack Member of the Omar Formation (figs. 1, 2A). Mixon (1985) correlated the Omar with similar deposits at the mouth of the Rappa-

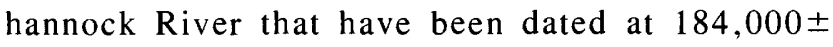
20,000 years by uranium-series analysis of an included coral (Mixon and others, 1982). The Nassawadox Formation forms the next younger unit on the Delmarva Peninsula (Mixon, 1985). On the basis of several uranium-series ages on corals, this unit is considered to be between 60,000 and 125,000 years in age (Mixon and others, 1982) (fig. 2A). The Kent Island Formation (Owens and Denny, 1979) is the youngest Pleistocene unit (fig. $2 A$ ) on the Delmarva Peninsula. A ${ }^{14} \mathrm{C}$ age of $28,450 \pm 660$ years (W-4643, U.S. Geological Survey Laboratory, Reston, Va.) was obtained from disseminated carbon in an organic-rich horizon at $3 \mathrm{~m}$ depth in the Kent Island Formation $18 \mathrm{~m}$ northwest of the Eastern Neck Island study site. Three other ${ }^{14} \mathrm{C}$ ages ranging from 26,000 to 32,000 years have been obtained for the Kent Island Formation (Owens and Denny, 1979). This age of about 30,000 years for the Kent Island is disputed, however, because Mixon (oral commun., 1982), on the basis of stratigraphic correlations, considered the surface of the unit to be between 40,000 and 60,000 years in age. This interpretation implies either that the ${ }^{14} \mathrm{C}$ age is derived from organic material deposited after the Kent Island sediments were exposed to subaerial weathering or that the organic materials are in an active spodic horizon, which would yield a younger ${ }^{14} \mathrm{C}$ age than the age of the parent material. Our data do not resolve the conflict.

The Omar and the Nassawadox Formations are each 6- to 25-m-thick deposits of fossiliferous clay, silt, and quartz sand; each unit was deposited during at least one major marine transgression. The Omar surfaces range in 


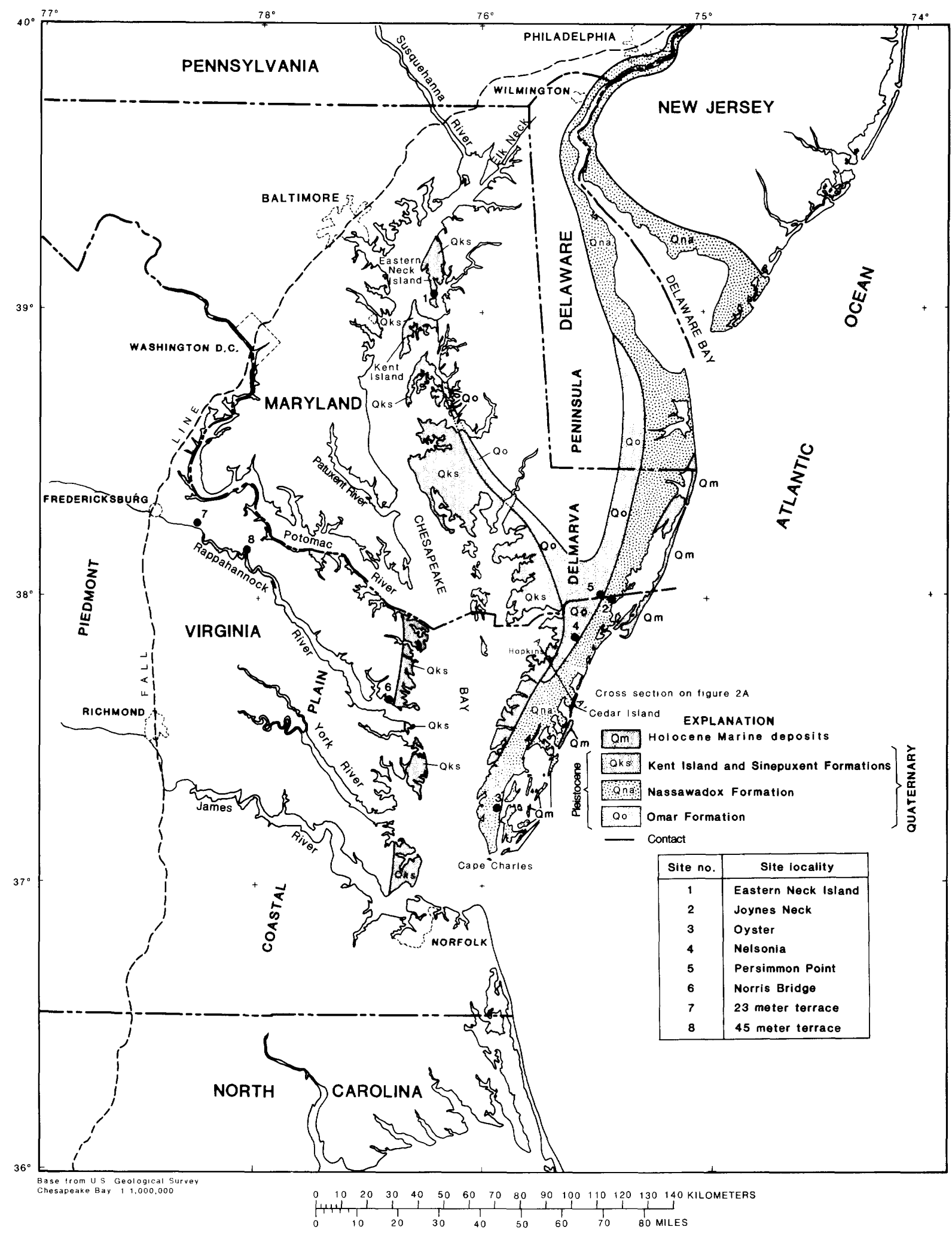

Figure 1. Map of the Coastal Plain of Virginia, Maryland, and Delaware showing late Quaternary geology and sample site locations. 


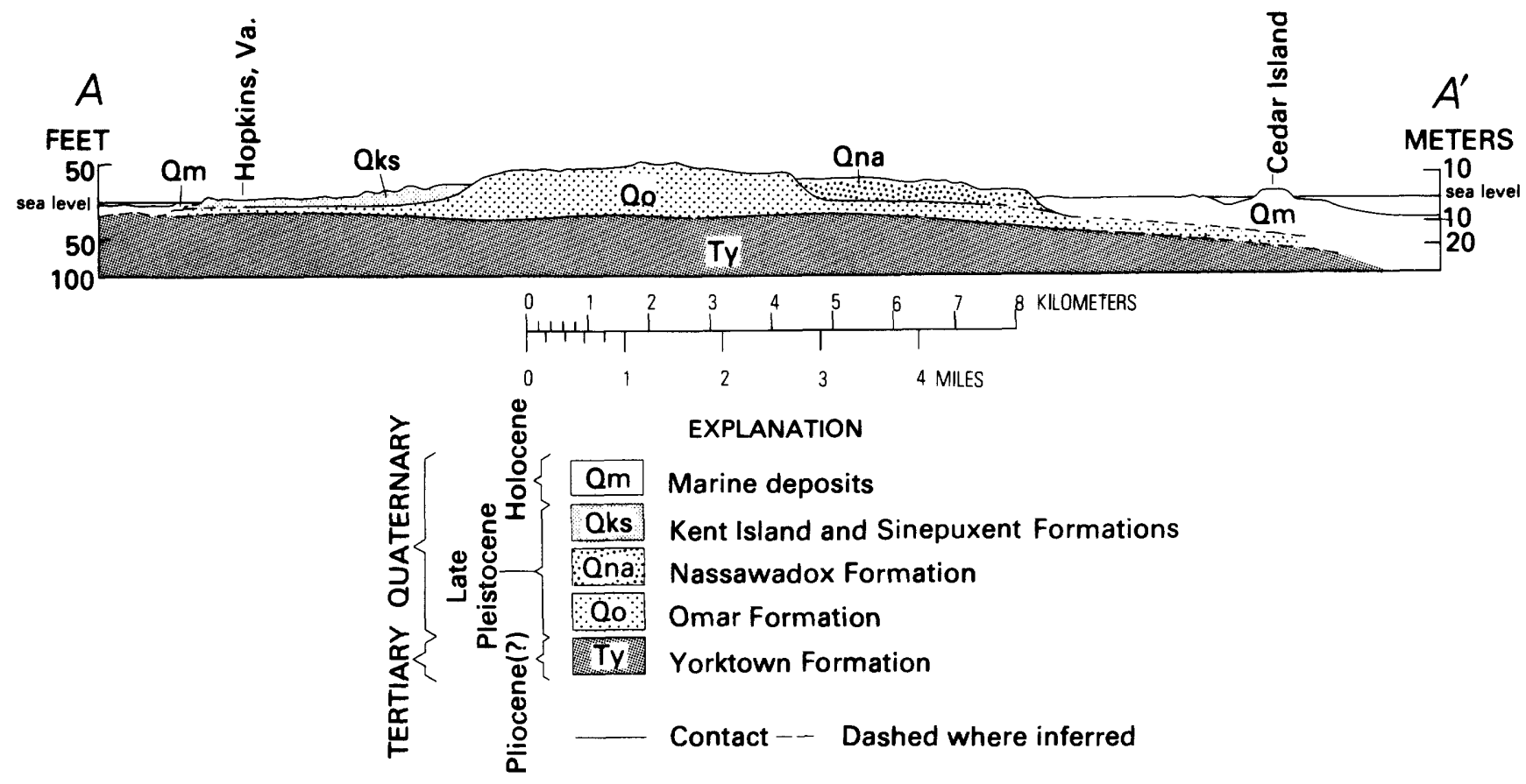

Figure 2A. Cross section showing geology across the southern Delmarva Peninsula (from Mixon, 1985). Location of section shown in figure 1.

altitude from 10 to $18 \mathrm{~m}$. The Nassawadox surfaces are only slightly lower, ranging from 4 to $10 \mathrm{~m}$ in altitude. The Kent Island Formation is a 12 -m-thick unit of thinly bedded sand and silt, with surface altitudes of $3 \mathrm{~m}$ in Virginia to more than $7 \mathrm{~m}$ at Eastern Neck Island (Owens and Denny, 1979; Mixon, 1985) (figs. 1, 2A).

The terrace at $12 \mathrm{~m}$ altitude at the mouth of the Rappahannock River (fig. $2 B$ ) is a planar surface underlain by a transgressive marine sequence of fossiliferous clay and cross-bedded quartz sand that ranges from 3 to $12 \mathrm{~m}$ thick (Newell, 1985). The fossiliferous marine clay near the base of this unit contained the coral dated at $184,000 \pm 20,000$ years (uranium-series analysis; Mixon and others, 1982). The older $23 \mathrm{~m}$ and $45 \mathrm{~m}$ altitude terraces along the lower Rappahannock River are underlain by fluvial and (or) estuarine sand, silt, and clay that contain little or no evidence of marine influence (fig. $2 B$ ). Neither terrace contains radiometrically dated material. The $23 \mathrm{~m}$ terrace is tentatively assigned an age of 500,000? years (Newell, 1985). The $45 \mathrm{~m}$ terrace is tentatively assigned an age of about 1.0 ? m.y. These ages are based upon correlations with the Canepatch and Waccamaw Formations, which have been dated in the Carolinas (McCartan and others, 1982). The source areas for the Rappahannock terrace deposits are the crystalline and intrusive rocks of the Piedmont and Blue
Ridge and the mafic intrusives and sedimentary rocks of the Mesozoic basins in Virginia.

\section{FIELD AND LABORATORY METHODS}

Except for site 1, all soil pedons were described and sampled by the authors and local SCS personnel. Horizon designations and descriptions follow the Soil Survey Manual (Soil Survey Staff, 1951) format. Analytically split samples were analyzed for standard physical and chemical characteristics (methods used are listed with their numerical codes in table 1) at the SCS National Soil Survey Laboratory (NSSL). The USGS laboratories conducted additional analyses including $\mathrm{X}$-ray diffraction of the $<2$ micron fraction (glycolated, $350^{\circ} \mathrm{C}, 500^{\circ} \mathrm{C}$ ); bulk chemistry by X-ray fluorescence; chemistry of the $<63$ micron fraction on selected sites; and oxalate extraction and atomic absorption of iron and aluminum. Only the X-ray diffraction patterns of the untreated $<2$ micron fraction are presented in the text.

The X-ray fluorescence analyses of the soil samples were performed on a Diano 8600 spectrometer after samples had been fused with lithium tetraborate. Major-element concentrations were then determined comparing unknown intensities for each element to calibration curves prepared 

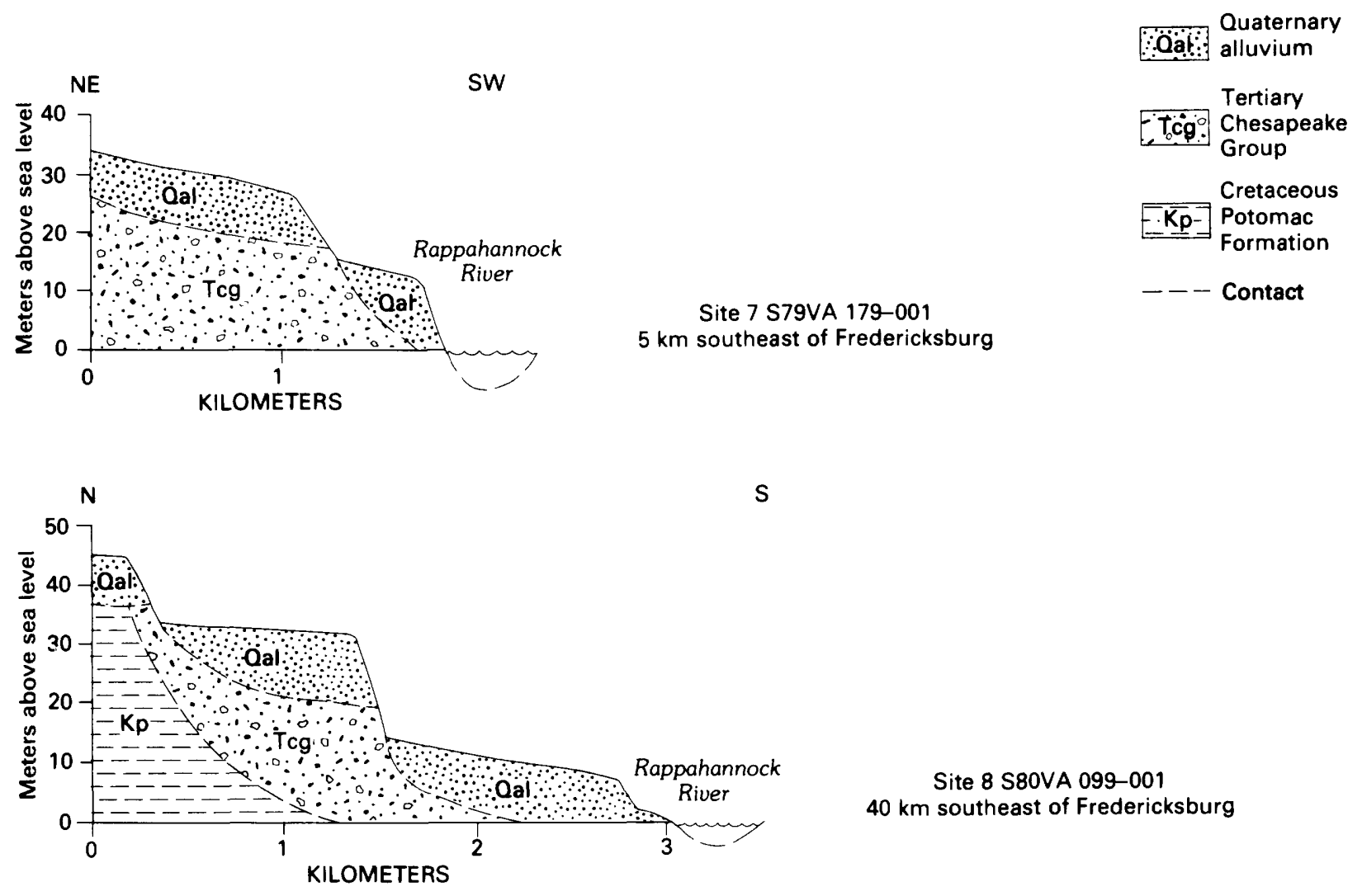

Site 8 S80VA 099-001
$40 \mathrm{~km}$ southeast of Fredericksburg

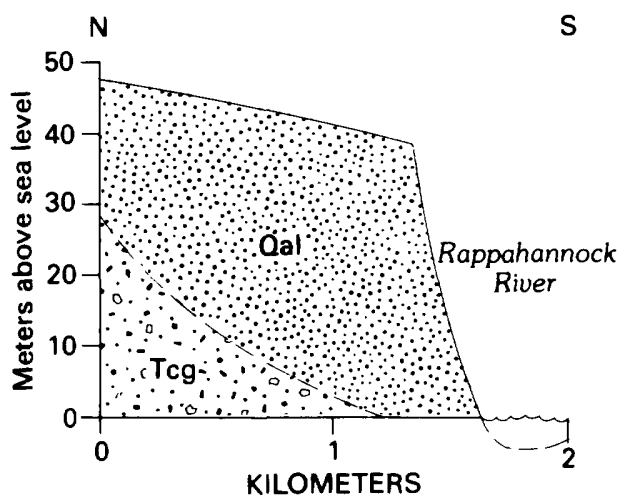

Site 6 S79VA 103-001

$80 \mathrm{~km}$ southeast of Fredericksburg

Figure $\mathbf{2 B}$. Cross sections showing geology at soil sampling sites 6,7 , and 8 , adjacent to the Rappahannock River south of Fredericksburg, $\mathrm{Va}$. Site locations are shown in figure 1.

from USGS silicate rock standards (Flanagan, 1976). This method usually results in relative errors of $<5$ percent.

\section{RESULTS AND DISCUSSION}

\section{Data Presentation}

The exact location of each study site and the field description of the soil and weathering profile described at the site are given in tables $2 A$ through $9 A$. Analytical results for samples from the profiles are presented in tables $2 B-2 E$ through $9 B-9 E$. The data are presented by study site. The study sites are arranged roughly from youngest to oldest. Figure 3 is a graphical presentation of the texture (on a clay-free basis) and weight percent of the $<2$ micron fraction for each profile, plotted by horizon. Figures 4 through 7 are graphic summaries of solum thickness, thickness of the argillic horizon, clay mass, and hue of Bt horizon plotted against either the determined or estimated age of the parent 
Eastern Neck: Site 1

\section{PERCENT FINER}

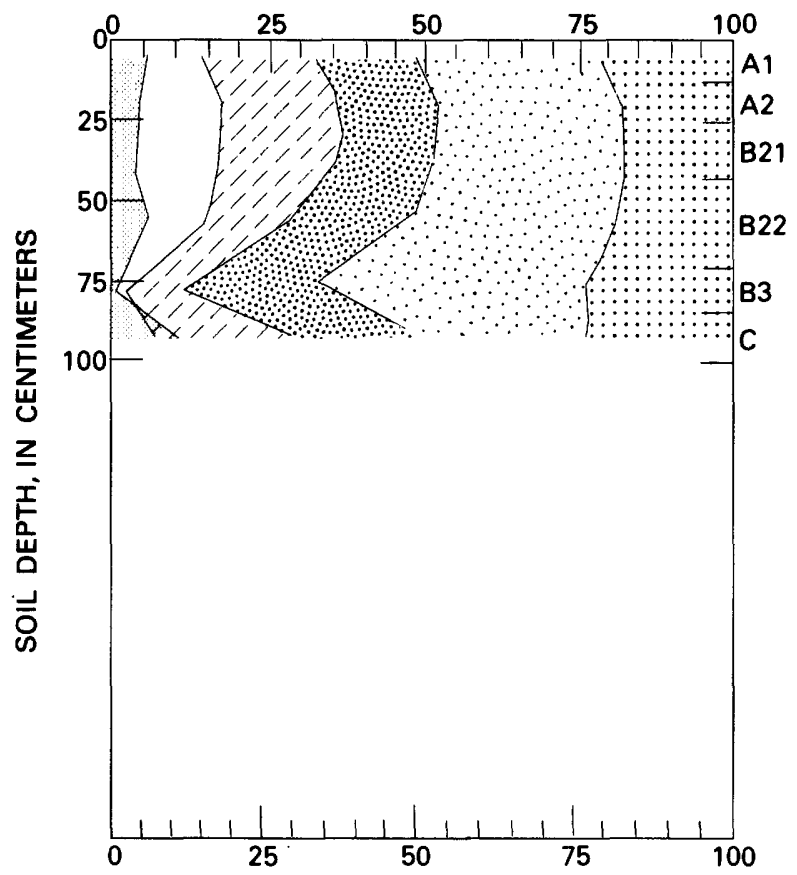

WEIGHT PERCENT $<2 \mu$ FRACTION OF WHOLE SOIL
Joynes Neck: Site 2

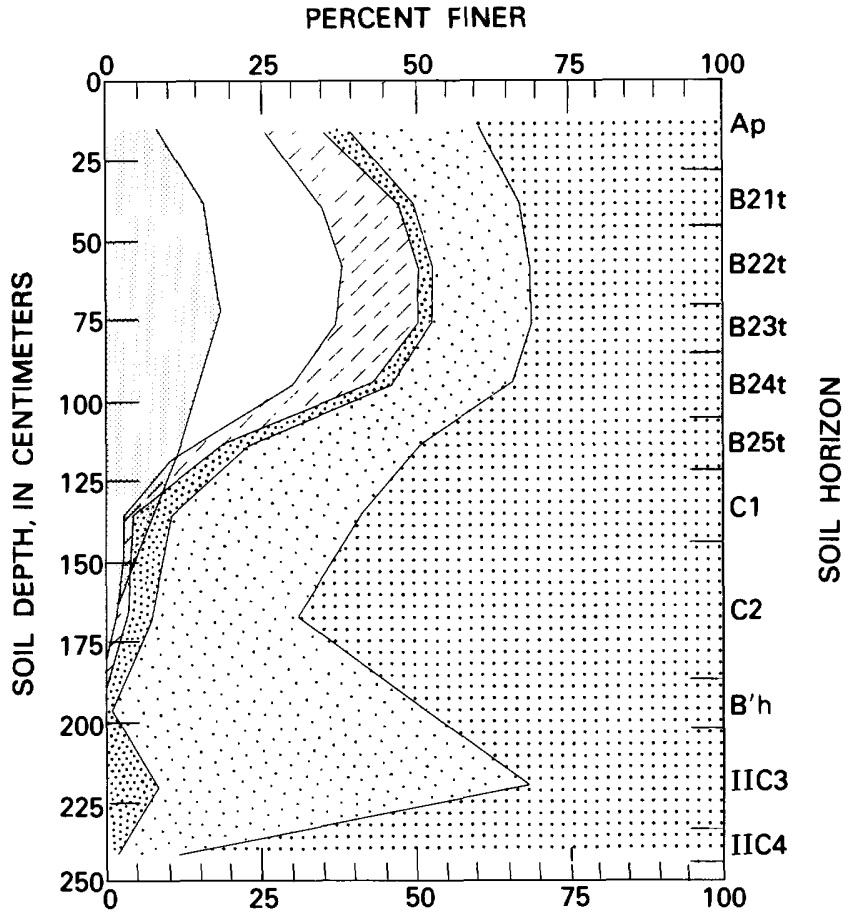

WEIGHT PERCENT $<2 \mu$ FRACTION OF WHOLE SOIL
Persimmon Point: Site 5

PERCENT FINER

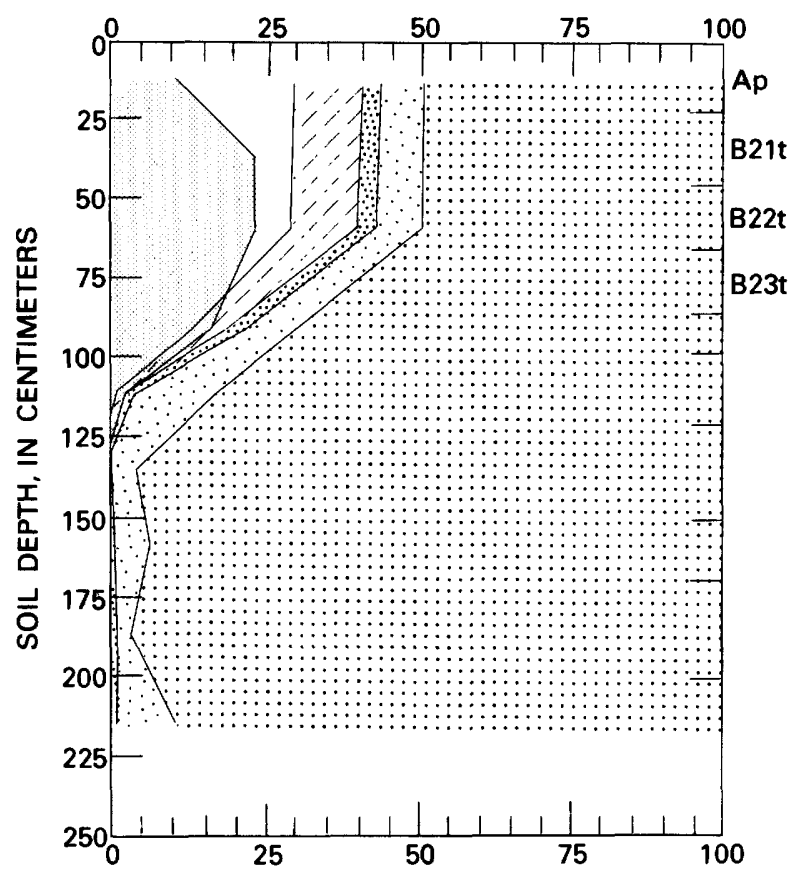

WEIGHT PERCENT $<2 \mu$ FRACTION OF WHOLE SOIL

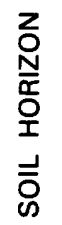

Norris Bridge: Site 6

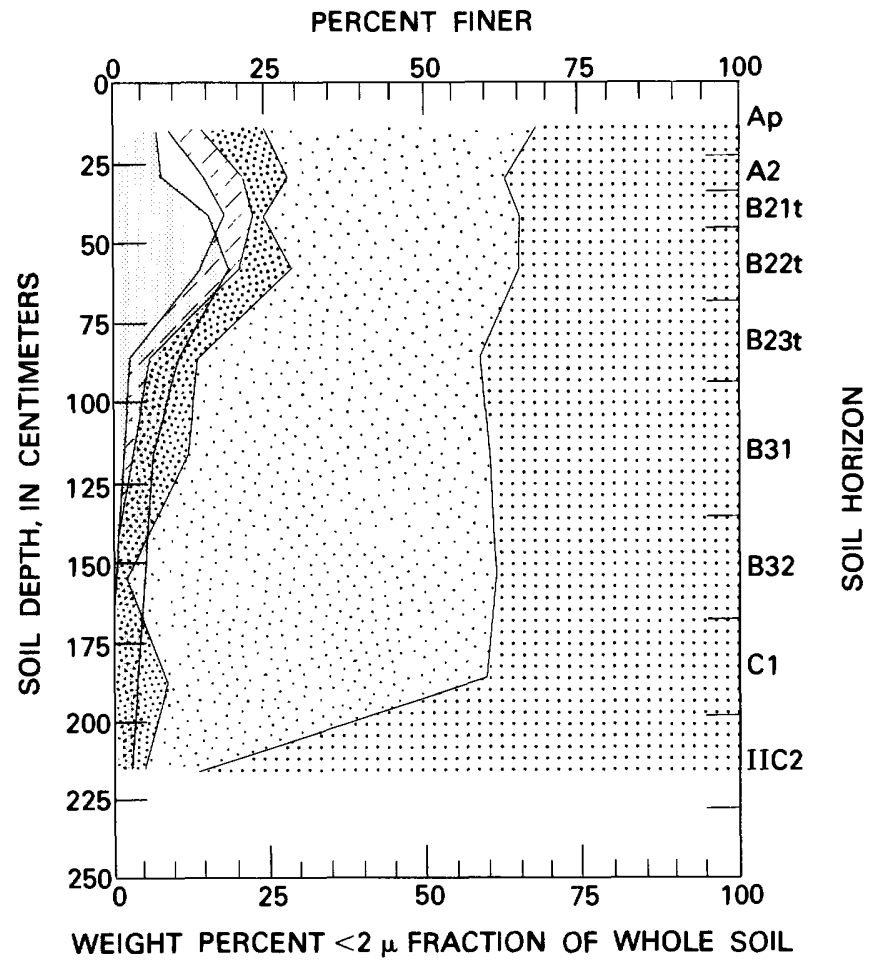

Figure 3. Texture (on a clay-free basis) and weight percent of the $<2$ micron fraction for all sites. 
Oyster: Site 3

\section{PERCENT FINER}

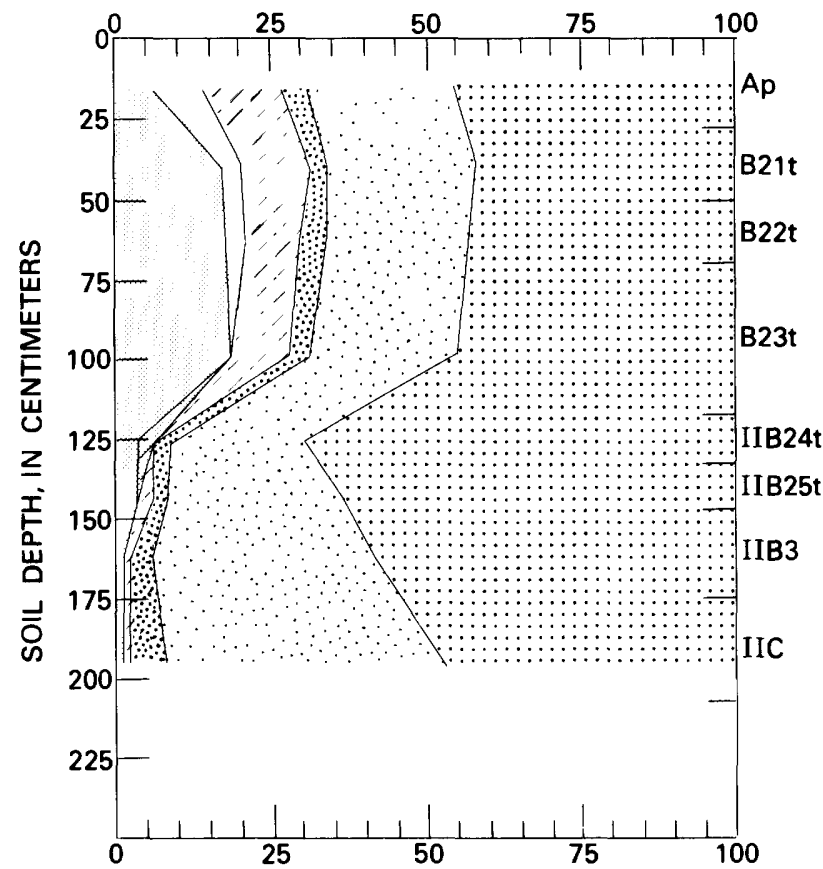

WEIGHT PERCENT $<2 \mu$ FRACTION OF WHOLE SOIL

23 m Terrace: Site 7

PERCENT FINER

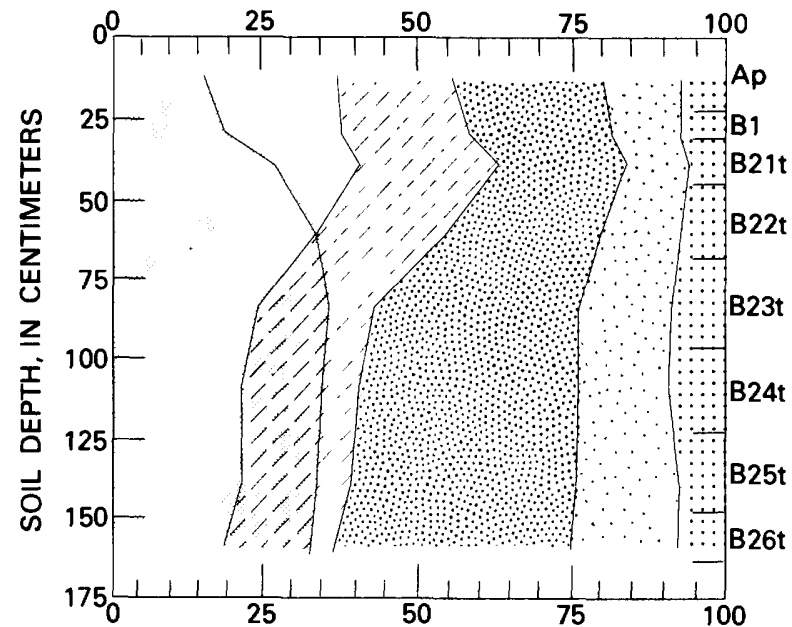

WEIGHT PERCENT $<2 \mu$ FRACTION OF WHOLE SOIL

EXPLANATION

GRAIN SIZE IN MICRONS
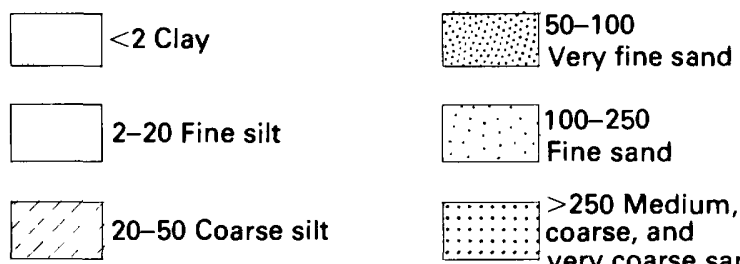

$>250$ Medium, coarse, and very coarse sand
Nelsonia: Site 4

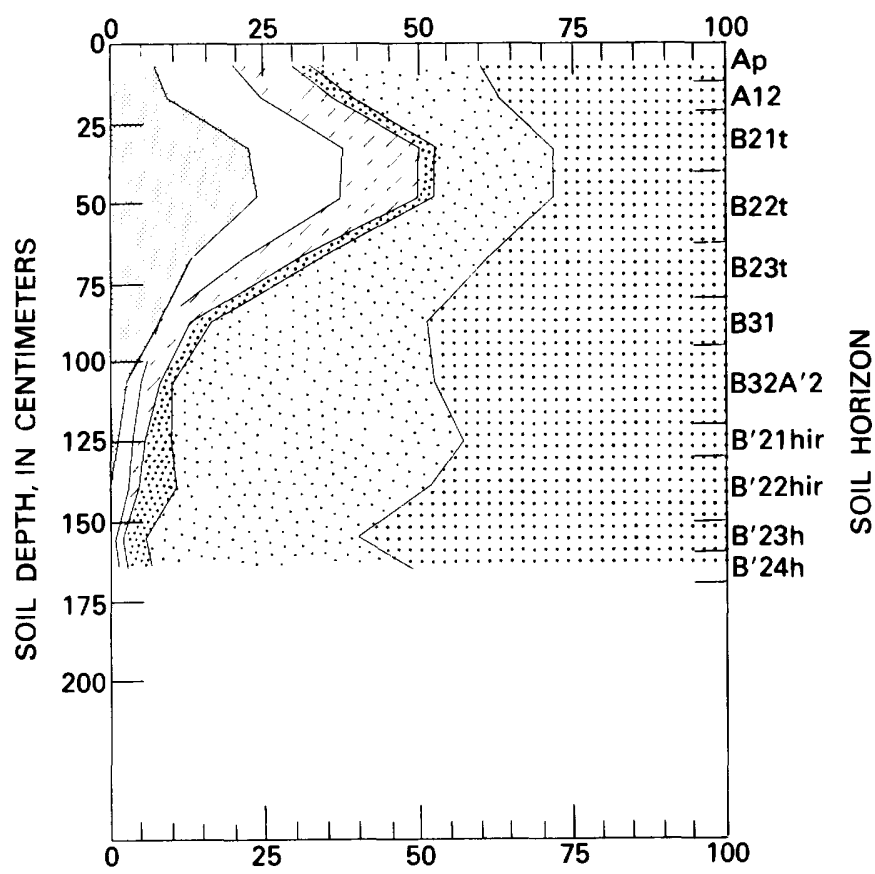

WEIGHT PERCENT $<2 \mu$ FRACTION OF WHOLE SOIL

$45 \mathrm{~m}$ Terrace: Site 8

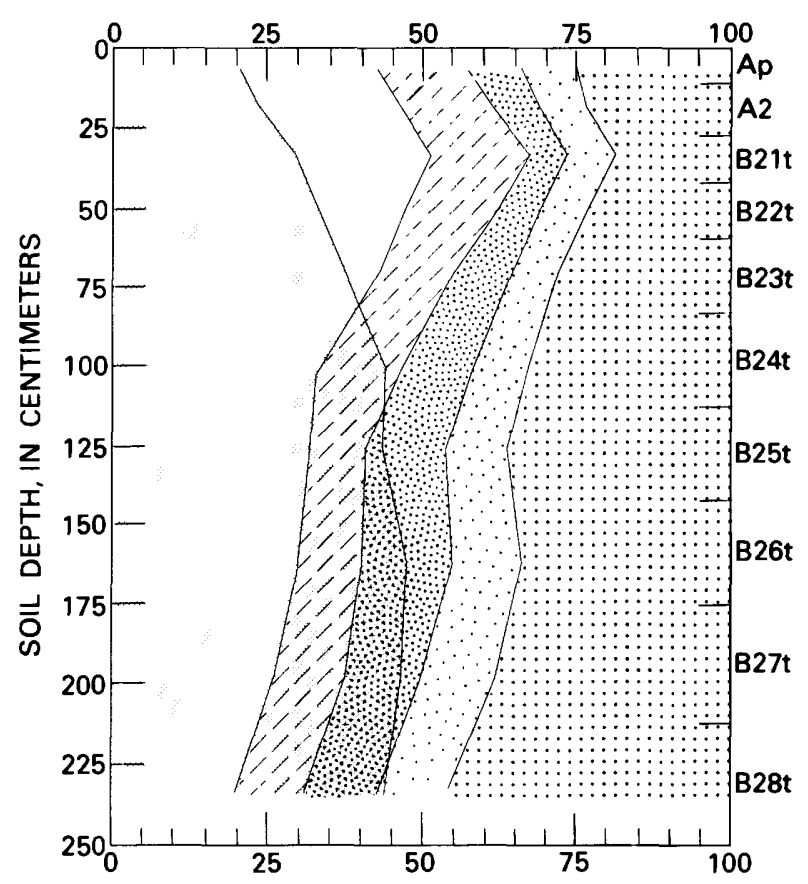

WEIGHT PERCENT $<2 \mu$ FRACTION OF WHOLE SOIL

Figure 3.-Continued 
material. Figures 8,9 , and 10 show the changes in chemical composition with increase in age of the soil: $\mathrm{Al}_{2} \mathrm{O}_{3}+\mathrm{Fe}_{2} \mathrm{O}_{3} /$ $\mathrm{SiO}_{2}$ ratio, $\mathrm{TiO}_{2}$, and $\mathrm{MnO}$, respectively. X-ray diffraction patterns of the $<2$ micron fraction are presented in figures 11 through 18 .

\section{Classification of Soils}

Most of the soils developed on the Piedmont and Coastal Plain of the middle and southern Atlantic coastal states are in the Ultisol soil order. Ultisols are found in the middle to low latitudes in areas that in some season experience greater precipitation than evapotranspiration, which allows water to move through the solum into the underlying parent material (Soil Survey Staff, 1975). In Ultisols, leaching removes bases at about the same rate as they are released by weathering. Most bases are held in the vegetation and in the upper few centimeters of the soil. Common clay minerals include kaolinite and hydroxy-interlayered vermiculite (HIV). Halloysite and gibbsite are also present in small amounts. Clay-size quartz, goethite, hematite, and mica are also common. Ultisols have a base saturation (by sum of the cations) that is $<35$ percent in the layer $1.5 \mathrm{~m}$ below the top of the argillic horizon or $1.8 \mathrm{~m}$ below the ground surface, whichever is shallower.

All of the soils described in this study are in the Udult suborder of Ultisols. Each of the soils described is in the fine-loamy, mixed, thermic Typic Hapludult family, with the exception of the fine-loamy, over clayey, mixed, thermic Typic Paleudult that has developed on the $45 \mathrm{~m}$ terrace. Hapludults are well-drained soils with an ochric epipedon and a thin to moderately thick argillic horizon. Hapludults are most numerous in the Piedmont, where the land surface is predominantly in slope, and on only moderately dissected surfaces in the lower Coastal Plain and along the drainages of the Coastal Plain and the Piedmont. Paleudults are commonly less permeable than Hapludults and are present on old stable land surfaces in the upper Coastal Plain and outer Piedmont, and on remnants of river terraces located two and three terraces above the present floodplain along Coastal Plain rivers. Paleudults have thick to very thick argillic horizons with low activity clays, similar to the clays of Oxisols present in tropical climates. Both Hapludults and Paleudults form on acid rocks or sediments that have an almost exclusive forest canopy, except where cultivated. In the 1938 (modified 1949) soil classification (Thorp and Smith, 1949) Hapludults in the thermic temperature regime were classified as Red-Yellow Podzolics, and in the mesic temperature regime were classified as Gray-Brown Podzolics. Paleudults in the same classification were almost exclusively Red-Yellow Podzolics.

\section{Physical Characteristics}

Soil texture of the B horizons is progressively finer in each older soil-from sandy loam and silt loam in the 30,000-year-old alluvium at Eastern Neck Island, to loam in the 60,000-120,000-year-old marine sands at Joynes Neck and Oyster, to loam and sandy clay loam in the 200,000year-old marine sands at Nelsonia, Persimmon Point, and Norris Bridge, to a silty clay loam in the 500,000?-year-old alluvium and (or) estuarine sediments of the $23 \mathrm{~m}$ terrace and clay loam of the similar 1.0?-m.y.-old sediments of the $45 \mathrm{~m}$ terrace (see tables $2 A$ through $9 A$ for field descriptions of soil profiles). Structure of the B horizons changes with the change in texture-from single grain at Eastern Neck, to medium subangular blocky at Joynes Neck, Oyster, and Persimmon Point, to medium and coarse subangular blocky at Norris Bridge, to medium and coarse prismatic at the 23 $\mathrm{m}$ site and coarse prismatic at the $45 \mathrm{~m}$ terrace site. With the increase in finer grained material and the change in texture from single grain to blocky to prismatic, there is a corresponding increase in thickness of B horizon, which is an argillic horizon in all but the youngest (Eastern Neck) profile, from $60 \mathrm{~cm}$ for Eastern Neck to $>220 \mathrm{~cm}$ for the profile on the $45 \mathrm{~m}$ site. Clay mass (percent clay $\times$ bulk density $\times$ thickness of horizon integrated over depth of solum) also increases with age of solum. Solum thickness increases similarly from $90 \mathrm{~cm}$ for Eastern Neck to $>220 \mathrm{~cm}$ for the $45 \mathrm{~m}$ terrace site. See figures 4 and 5 for plots of solum and $B$ horizon thickness vs. age of soil. Figure 6 presents the plot of clay mass vs. age. A plot of hue of the Bt horizons vs. age of solum shows a trend toward increasing redness with increasing age (fig. 7).

Textural analysis data, by weight percent, for each solum and underlying parent material (where encountered) are presented in tables $2 B$ through $9 B$. Fine-grained and very fine grained sand are the dominant sand-size fractions. The solum that developed in the 1.0?-m.y.-old $45 \mathrm{~m}$ terrace alluvium has the most even distribution of sand-size fractions. The Norris Bridge site has the largest percentage of medium-size sand distributed through the profile. The silt fraction is most evenly distributed between fine and coarse silt in the Eastern Neck profile, which is of alluvial and (or) estuarine origin. All other profiles on the Delmarva Peninsula have a $2: 1$ to $3: 1$ ratio of fine silt to coarse silt in the upper $1 \mathrm{~m}$, below which is an abrupt decrease in silt- and clay-size fractions and a corresponding increase in total percent sand. The profiles of the Delmarva Peninsula all have marine sand as parent material. A similar "silt cap" can be seen in the profile at Norris Bridge, which also has marine sands as parent material. But the profiles in the alluvium of the $23 \mathrm{~m}$ and $45 \mathrm{~m}$ terraces do not show the sharp contact between the fine and coarse fraction percentages at $1 \mathrm{~m}$ depth; the silt decreases gradually downward through the profile. 


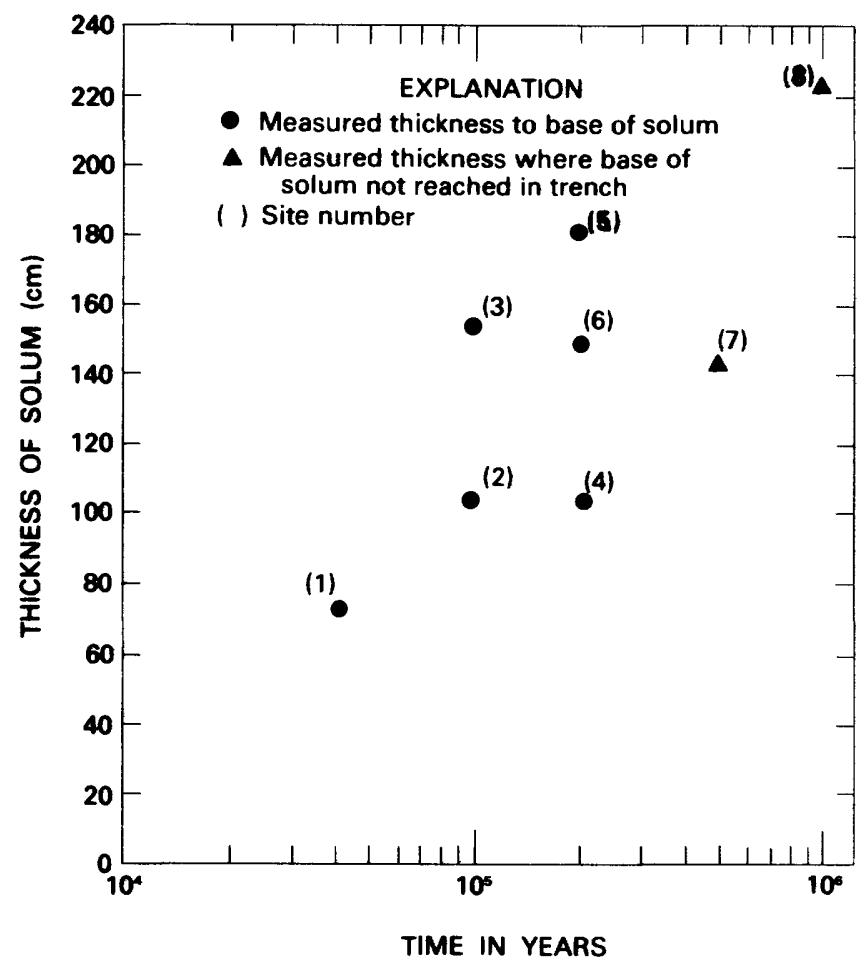

Figure 4. Solum thickness of soil profiles plotted against age. Data from tables $2 A$ through $9 A$.

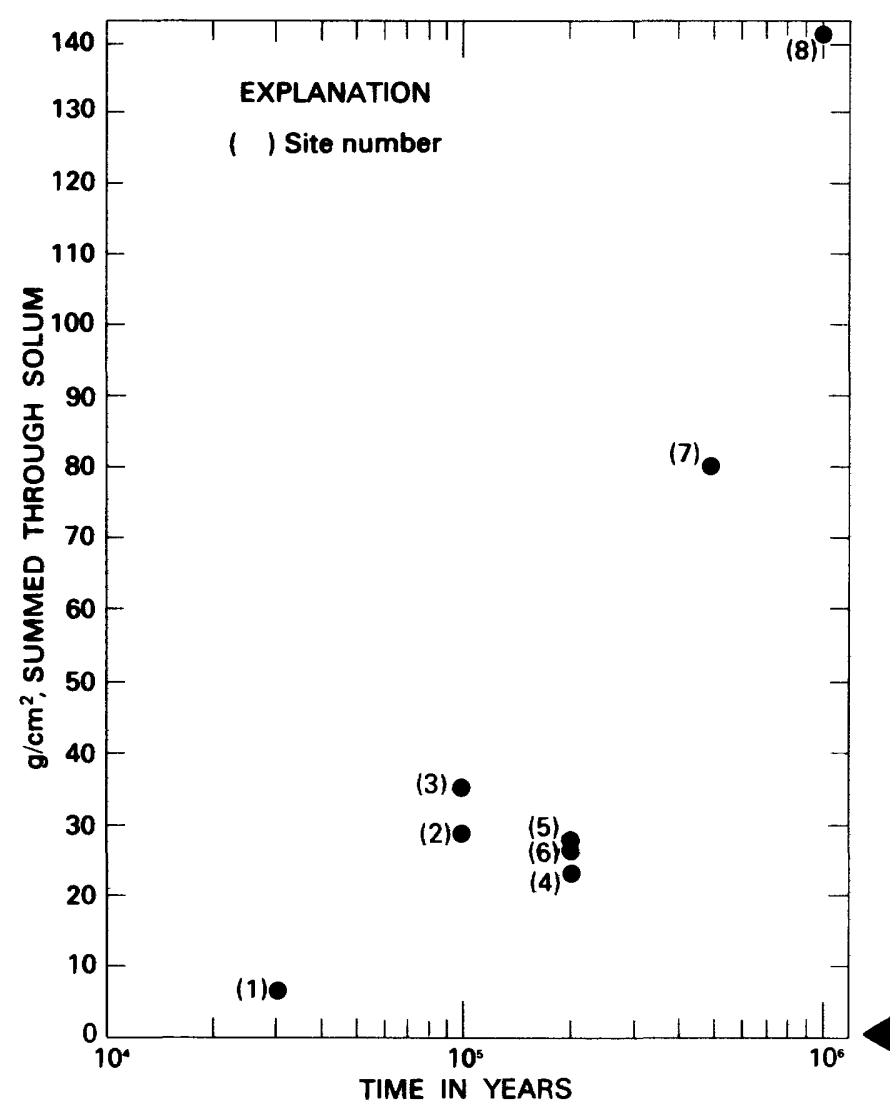

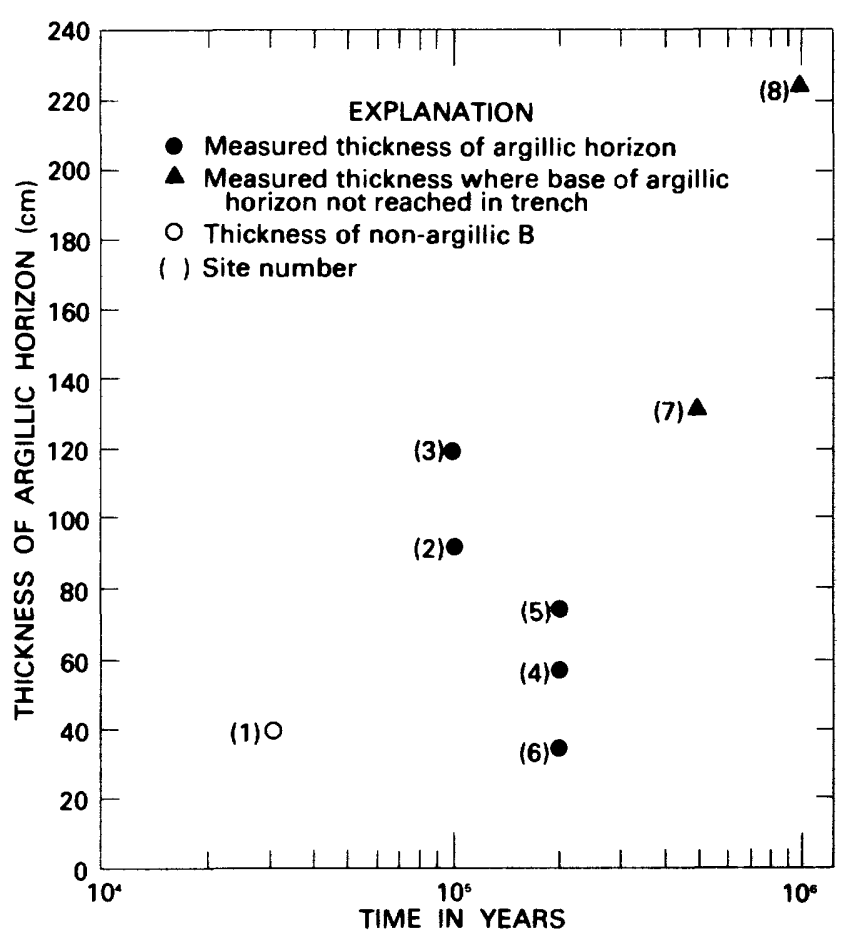

Figure 5. Thickness of argillic (Bt) horizons plotted against age. Data from tables $2 A$ through $9 A$.

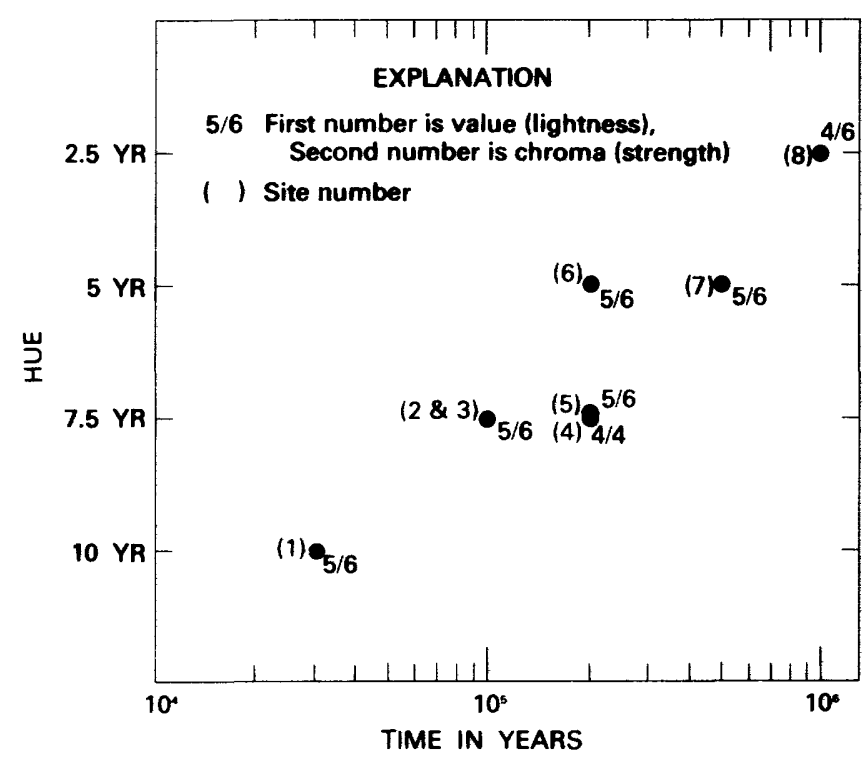

Figure 7. Hue of argillic $(\mathrm{Bt})$ horizons plotted against age. Data from tables $2 A$ through $9 A$.

Figure 6. Clay mass of solum (weight percent clay $\times$ bulk density $\times$ horizon thickness of each horizon summed for pedon) plotted against age. Data from tables $2 B, C$, and $D$ through $9 B$, $C$, and $D$. 


\section{Chemical Characteristics}

General bulk chemistry of each profile is presented in tables $2 C$ through $9 C$. Data are reported as weight percent of oxides in each of the soil horizons. The general chemistry is similar for each of the soils. As seen in figure 8, the $\mathrm{Fe}_{2} \mathrm{O}_{3}+\mathrm{Al}_{2} \mathrm{O}_{3} / \mathrm{SiO}_{2}$ ratio increases as soil age increases. $\mathrm{SiO}_{2}$ decreases from $>90$ percent in the $\mathrm{B}$ horizons of the 30,000 -year-old soil at Eastern Neck Island, to 66-90 percent in the B horizons of both the 60,000 - to 120,000 -yearold soils at Joynes Neck and Oyster and the 200,000-yearold soils at Nelsonia, Persimmon Point, and Norris Bridge, to $65-75$ percent in the $B$ horizons of the 500,000 ?-year-old $23 \mathrm{~m}$ terrace and the 1.0 ?-m.y.-old $45 \mathrm{~m}$ terrace soils. In the same $\mathrm{B}$ horizons, $\mathrm{Al}_{2} \mathrm{O}_{3}$ increases from $<5$ percent at Eastern Neck, to between 5 and 10 percent in the 60,000 - to 200,000 -year-old soils, to about 14 to 17 percent in the $23 \mathrm{~m}$ terrace soil, and decreases to about 14 percent in the $45 \mathrm{~m}$ terrace soil. $\mathrm{Fe}_{2} \mathrm{O}_{3}$ in the $\mathrm{B}$ horizons increases from about 1.5 percent at Eastern Neck to about 3 percent at Joynes Neck and Oyster, to 2.5 to 4.5 percent at Nelsonia, Persimmon Point, and Norris Bridge, to 5 to 8 percent in the $23 \mathrm{~m}$ terrace soil, and decreases to about 6 percent in the $45 \mathrm{~m}$ terrace soil. Decreases in $\mathrm{SiO}_{2}, \mathrm{Al}_{2} \mathrm{O}_{3}$, and $\mathrm{Fe}_{2} \mathrm{O}_{3}$ correspond to a change in clay mineralogy (relative abundance of the hydroxy-interlayered vermiculite to kaolinite) in the $45 \mathrm{~m}$ terrace soil as compared to the $23 \mathrm{~m}$ terrace or any younger soil. $\mathrm{TiO}_{2}$ shows a general trend of increasing in successively older soils but nearly doubles in amount from the 60,000 - to 200,000 -year to the 500,000 ?-year-old soils (fig. 9). $\mathrm{TiO}_{2}$ also decreases in the 1.0 ?-m.y.-old soil $(45 \mathrm{~m}$ terrace soil) relative to the 500,000 ?-year-old soil $(23 \mathrm{~m}$ terrace soil). $\mathrm{MnO}$ shows an increasing trend similar to that of $\mathrm{TiO}_{2}$ but with greater range in the values for a given soil and not as clear a decrease between the $23 \mathrm{~m}$ and $45 \mathrm{~m}$ terrace soils (fig. 10).

The ratio of the cation exchange capacity (CEC) to percent clay shows a general trend of decreasing in the older soils but is similar among the 60,000 - to 200,000 -year-old soils (tables $3 D$ through $9 D$ ). This general decrease in the ratio in the older soils most likely reflects a progressive increase in HIV low charge clay, which results in a decrease in the total number of exchange sites. Most of the exchange sites that are available are saturated with aluminum.

\section{Mineralogy of the $<2$ Micron Fraction}

Kaolinite, HIV, and quartz are the major components of the clay-size fraction of all the Delmarva and Rappahannock River terrace soils. Trends in clay mineralogy of the profiles appear to be related to degree of weathering and to position within profile. HIV increases toward the surface in

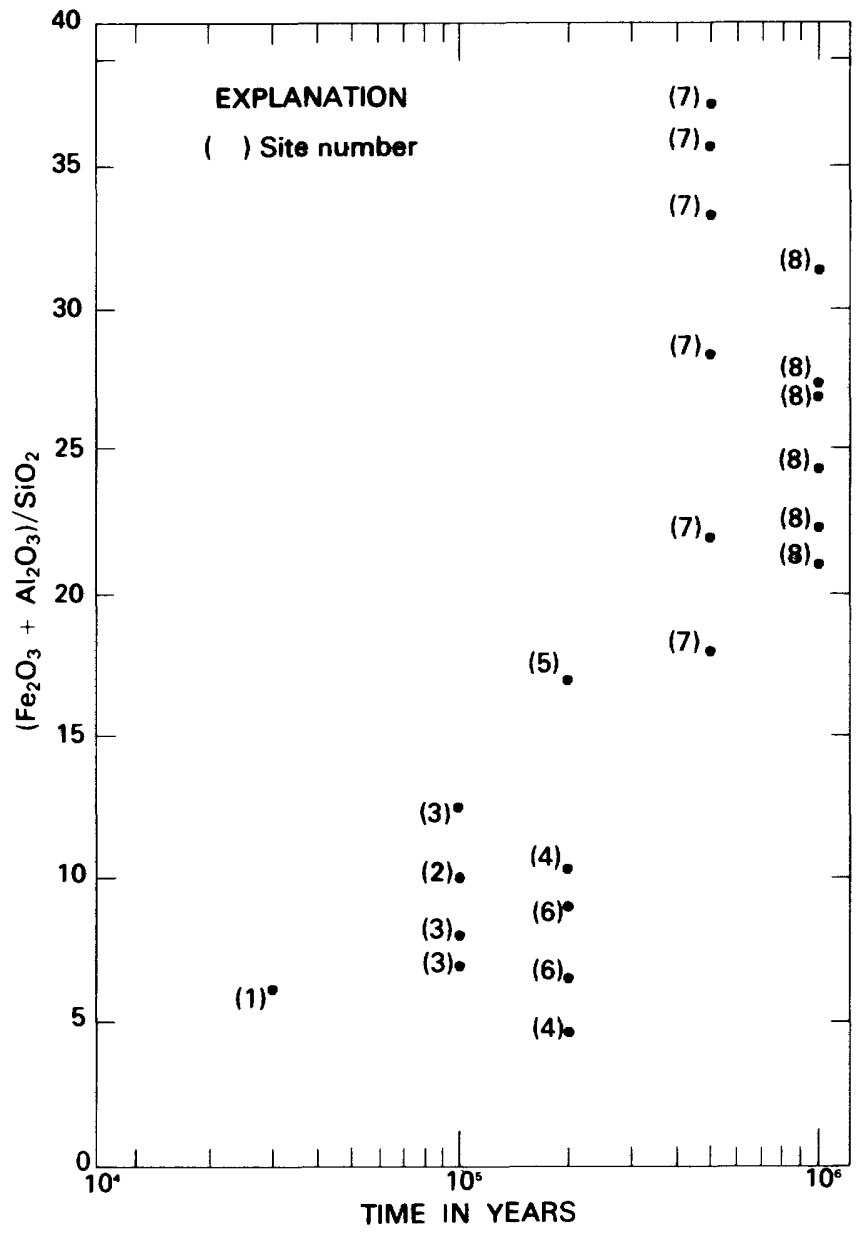

Figure 8. $\mathrm{Fe}_{2} \mathrm{O}_{3}+\mathrm{Al}_{2} \mathrm{O}_{3} / \mathrm{SiO}_{2}$ of sola plotted against age. Data from table $2 \mathrm{C}$ through $9 \mathrm{C}$.

all but the $45 \mathrm{~m}$ terrace profile (figs. 11-18), in which there is an apparent increase of kaolinite relative to HIV in the weathered parent material ( $\mathrm{C}$ horizon) in the upper part of the $B$ and in the A horizons. Other than the $45 \mathrm{~m}$ terrace, HIV is more abundant in each older soil. Both the increase toward the surface and the increase with age of soil suggest that the increase in HIV is a trend associated with degree of weathering, at least in soils $<500,000$ ? years in age.

In the Oyster profile (fig. 13) we see that HIV and gibbsite have strongest peak intensities above and below the B23t horizon. In the B23t and 2B24t horizons we see strong 4.5 A peaks that we interpret as a diffraction peak of halloysite. This peak was shown by scanning electron microscopy to correlate with the occurrence of halloysite in horizons of the Pensauken Formation at Betterton, Md., by Owens and Minard (1979). We interpret the abundance of the halloysite in the argillic horizons as the result of water retention in the Bt relative to superjacent and subjacent horizons. The higher soil water content of the clay loam B2 horizon relative to coarser textured $\mathrm{B} 1$ and $\mathrm{B} 3$ horizons has been documented by Bruce and Whisler (1973). We interpret the greater abundance of HIV and gibbsite above and 


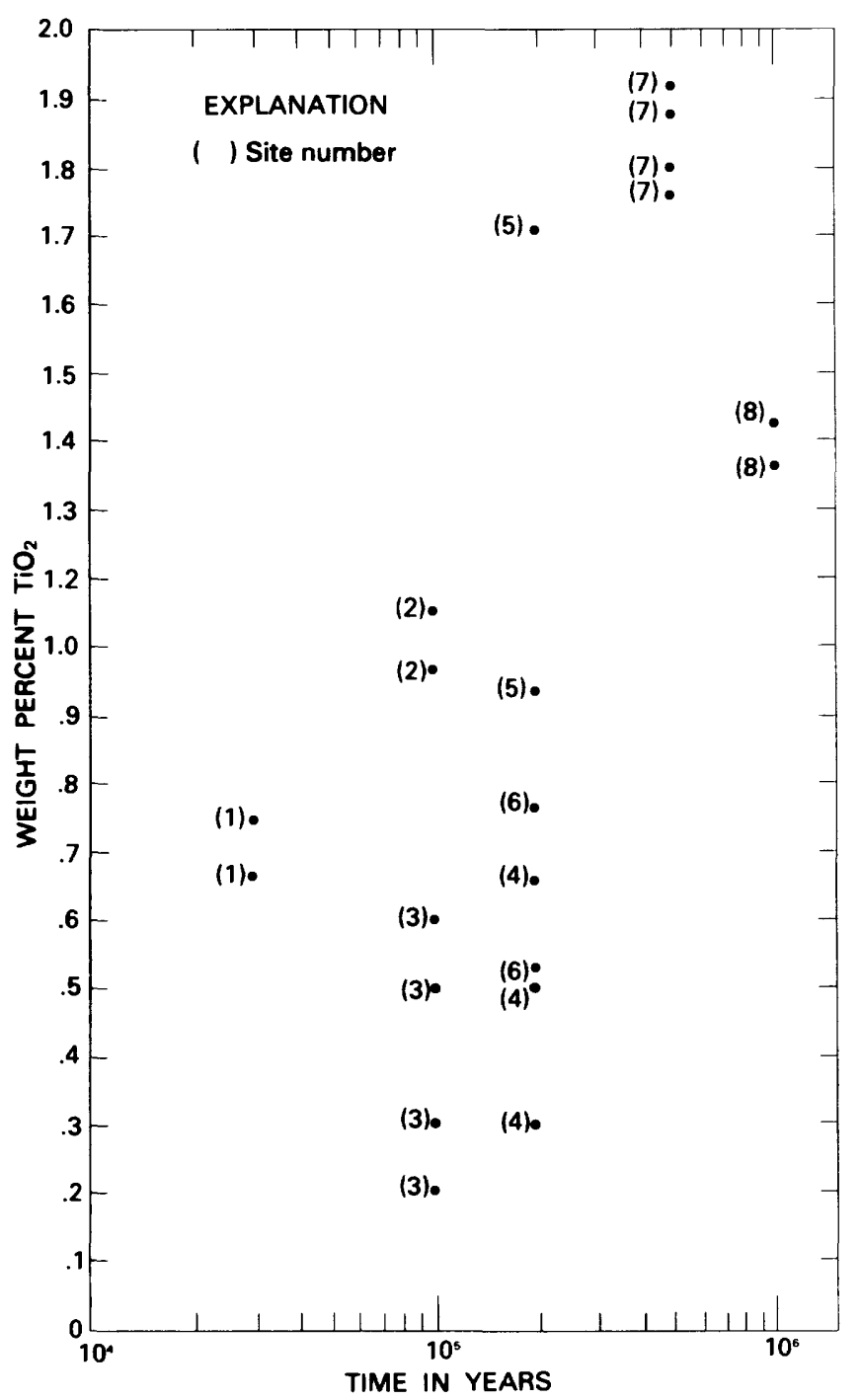

Figure 9. Weight percent $\mathrm{TiO}_{2}$ plotted against age. Data from tables $2 B$ through $9 B$.

below the halloysite-rich horizons as reflecting the drier soil microenvironments in these horizons that are different from the relatively wetter microenvironments in horizons B23t and 2B24t. These observations warrant further study in soils in which water movement is well understood.

Increase in HIV relative to kaolinite and gibbsite in the A horizon could be due to inheritance of HIV transformed from a 10 A precursor or aeolian contribution. However, we hypothesize that the HIV is formed in situ and may form preferentially in the A horizons due to chemical processes that attack kaolinite and (or) facilitate in-situ formation of vermiculite. HIV is commonly seen to increase upward into the A horizons of Ultisols (Barnheisel and Rich, 1966; Rich, 1968; Karathanasis and others, 1983). The relative increase in kaolinite and decrease in HIV in the soil of the $45 \mathrm{~m}$ terrace are associated with increases in total clay, percent clay in the upper horizons, and increase in $\mathrm{Fe}_{2} \mathrm{O}_{3}$ and $\mathrm{Al}_{2} \mathrm{O}_{3}$ relative to $\mathrm{SiO}_{2}$, as well as an increase in the total

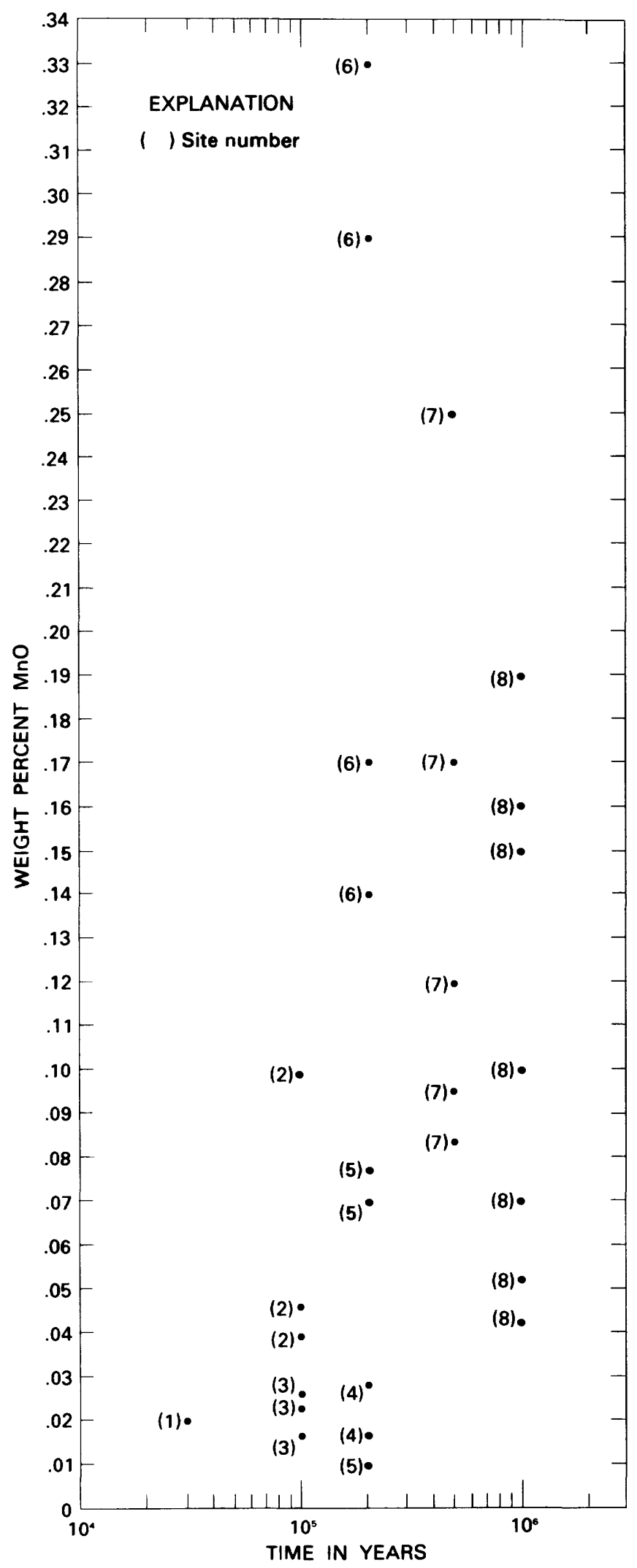

Figure 10. Weight percent $\mathrm{MnO}$ plotted against age. Data from tables $2 B$ through $9 B$. 


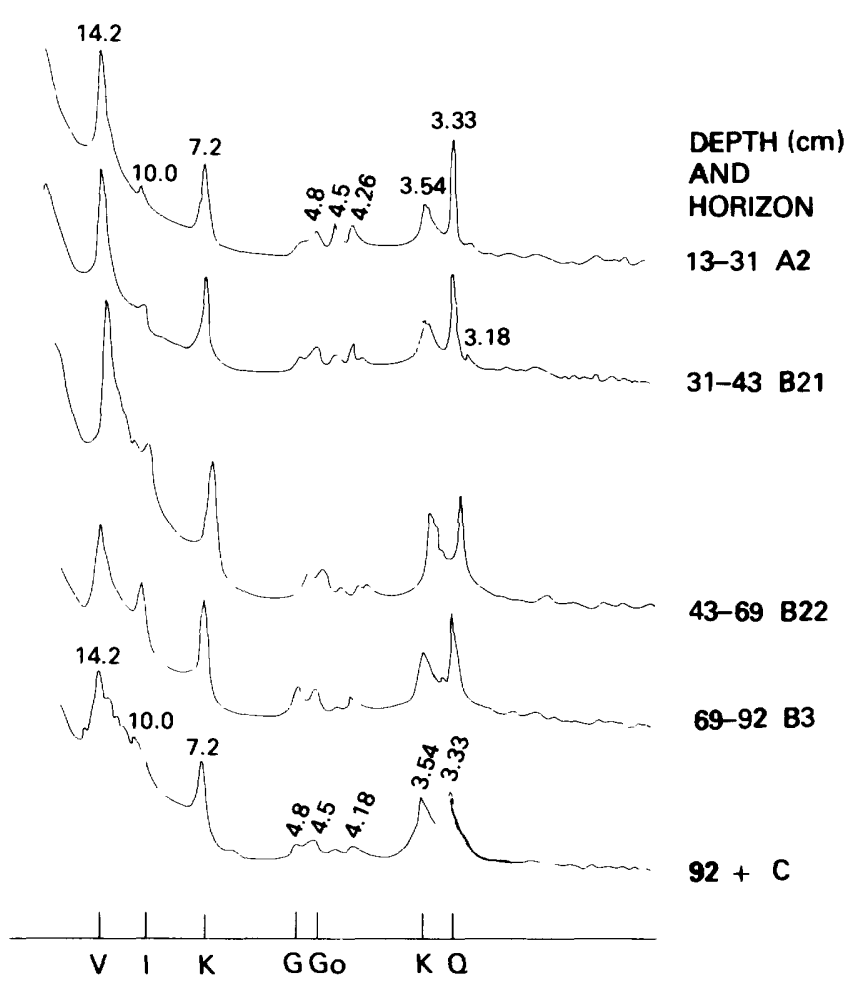

Figure 11. X-ray diffraction patterns for untreated $<2$ micron fractions from selected soil horizons, Eastern Neck, site 1 (exact location and field description in table $2 A$ ). Traces illustrated are of oriented, untreated clay. Peak spacings are in angstroms (A). Depths to middles of horizons are given in centimeters. $\mathrm{V}$ is hydroxyl-interlayered vermiculite, $\mathrm{I}$ is illite, $\mathrm{K}$ is kaolinite, $\mathrm{G}$ is gibbsite, Go is goethite, and $Q$ is quartz. Vermiculite peak intensity increases toward the surface. The illite peak intensity decreases above the $\mathrm{B} 22$ horizon.

$\mathrm{TiO}_{2}$ (table $9 \mathrm{C}$ and figs. 5, 6, 8, and 9). This decrease in HIV in the $45 \mathrm{~m}$ terrace soil may be due to depletion of the source of readily soluble silica. The large percentage of clay in the A horizon of this solum may produce a drainage environment in which the stability of kaolinite is greater than that of HIV and gibbsite (that is, analogous to the B23t in the Oyster profile).

In support of this hypothesis, we have plotted the ratio of peak heights of

$\frac{\text { HIV }(14 \mathrm{~A})+\text { gibbsite }(4.8 \mathrm{~A})}{\text { kaolinite }(7.2 \mathrm{~A})+\text { halloysite }(4.5 \mathrm{~A})}$ vs. percent clay $\times$ horizon thickness $(\mathrm{cm})$

for Oyster (site 3), Persimmon Point (site 5), the $23 \mathrm{~m}$ terrace (site 6 ) and the $45 \mathrm{~m}$ terrace (site 7). Figure 19 shows the increase in the HIV and gibbsite above the textural B horizons. With increasing depth and clay percentage, the ratio decreases. Moreover, going from the youngest soil to the oldest soil, the slopes of the hand-drawn best-fit lines decrease. For younger soils there is considerable scatter

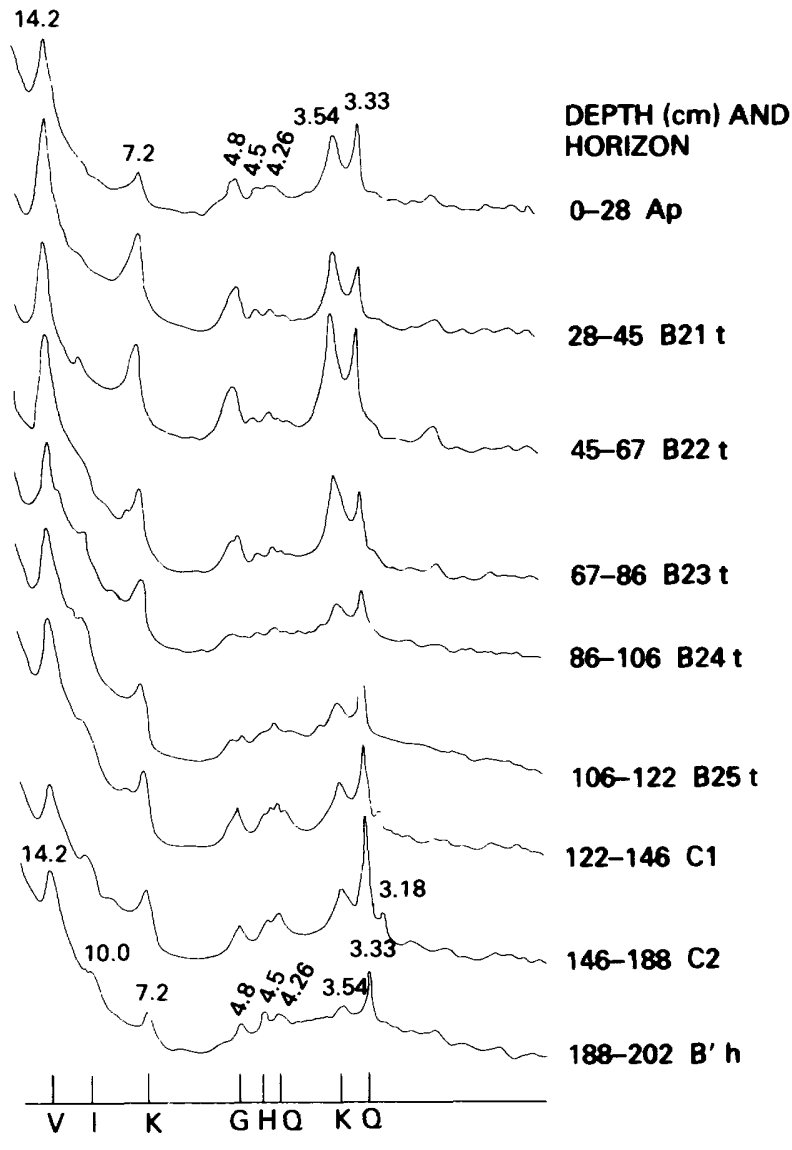

Figure 12. X-ray diffraction patterns for untreated $<2$ micron fractions from selected soil horizons, Joynes Neck, site 2 (exact location and field description in table $3 A$ ). Traces illustrated are of oriented, untreated clay. Peak spacings are in angstroms (A). Depths to middles of horizons are given in centimeters. $V$ is hydroxy-interlayered vermiculite, $\mathrm{I}$ is illite, $\mathrm{K}$ is kaolinite, $\mathrm{G}$ is gibbsite, $\mathrm{H}$ is halloysite, and $\mathrm{Q}$ is quartz. Gibbsite peak intensity increases both above and below the Bt horizon. The ratio of $4.5 \mathrm{~A}$ halloysite to $4.85 \mathrm{~A}$ gibbsite is a maximum in the B24t horizon.

around the lines connecting the maximum and minimum ratios. We interpret the existence of the trends as showing that the younger, less clay-rich soils have more drainage microenvironments in which the formation of HIV and gibbsite occur than do the older soils. We cannot propose a simple mechanism to explain the relative phase abundances but note that the changes in ratios appear to be related to increasing age and decreasing drainage.

\section{The Loess Problem}

Because the upper $1 \mathrm{~m}$ of most soils on the Delmarva Peninsula is generally more silty than the lower part of the sola, the question arises as to whether or not loess is a significant constituent of these soils. The presence of loess 


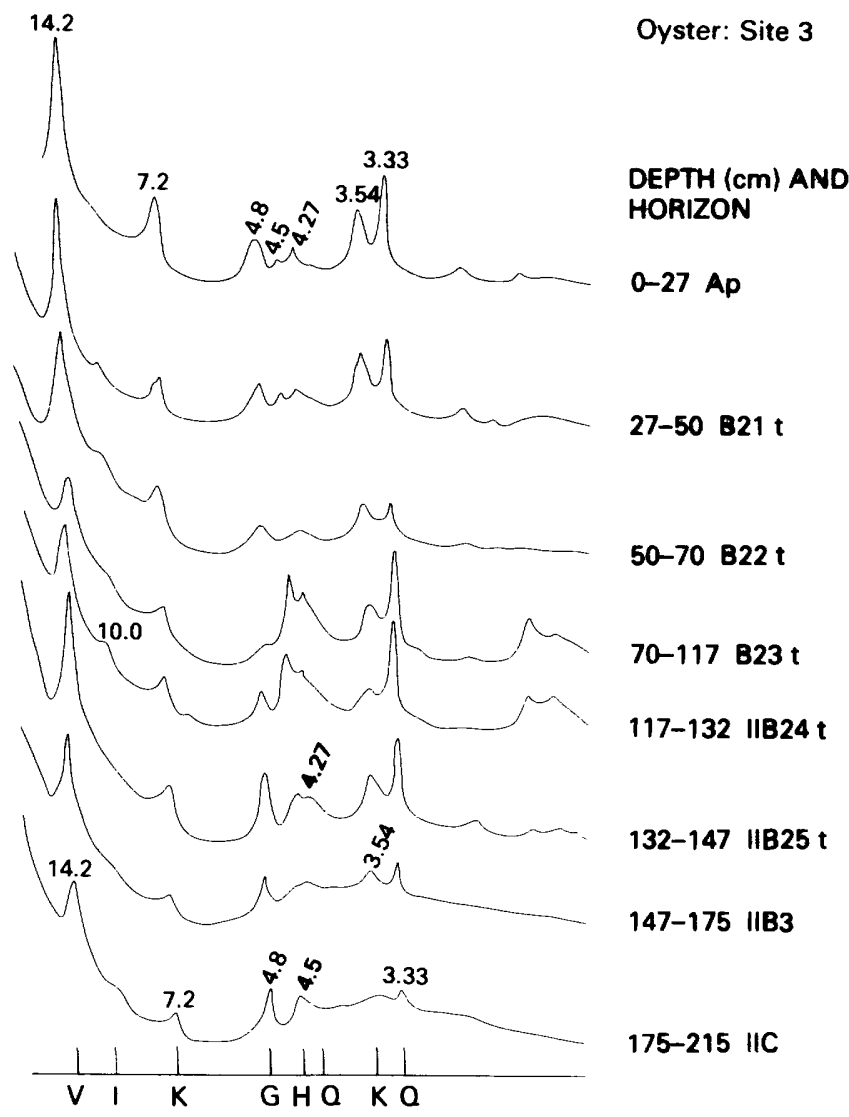

Figure 13. X-ray diffraction patterns for untreated $<2$ micron fractions from selected soil horizons, Oyster, site 3 (exact location and field description in table $4 A$ ). Traces illustrated are of oriented, untreated clay. Peak spacings are in angstroms (A). Depths to middles of horizons are given in centimeters. $V$ is hydroxy-interlayered vermiculite, $I$ is illite, $K$ is kaolinite, $G$ is gibbsite, $\mathrm{H}$ is halloysite, and $\mathrm{Q}$ is quartz. Halloysite peak intensity is greatest in the Bt horizon, and vermiculite and gibbsite peak intensities increase above and below the Bt horizon.

on the Eastern Shore was first suggested by Foss and others (1978) and Simonson (1982). Each of the pedons sampled for this study has a significant percentage of fine silt ( 2 to 20 microns) in the Bt horizons. These relatively high silt values suggest that there may be a significant fraction of aeolian silt (loess) in the total silt fraction of soils on the Delmarva Peninsula (Lewis and others, 1984).

The eight sites sampled for this study are in the southern Delmarva Peninsula and adjacent areas and were selected because they appeared to be in uneroded parts of the landscape and to have had minimal accretion from aeolian and (or) colluvial materials. The soils described by Foss and others (1978) average 76 percent silt and 24 percent sand on a clay-free basis. Our study profiles average 35 percent silt, significantly less than the 76 percent silt reported by Foss and others (1978) but much higher than the 5 to 10 percent silt below $1 \mathrm{~m}$ depth in these sola and in their underlying $\mathrm{C}$ horizons.

Evidence suggests either that all of the fine silt fraction in soils on the Delmarva Peninsula may not be of
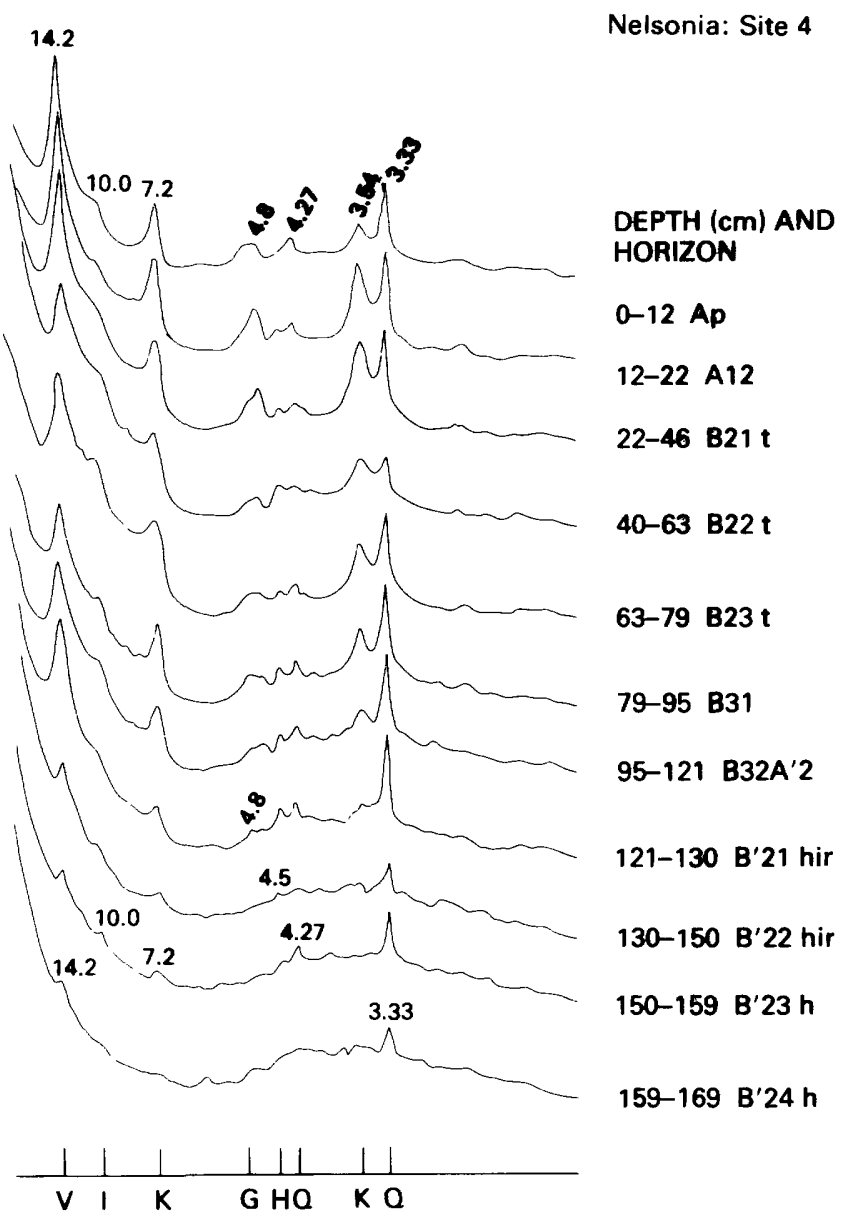

Figure 14. X-ray diffraction patterns for untreated $<2$ micron fractions from selected soil horizons, Nelsonia, site 4 (exact location and field description in table 5A). Traces illustrated are of oriented, untreated clay. Peak spacings are in angstroms (A). Depths to middles of horizons are given in centimeters. $V$ is hydroxy-interlayered vermiculite, $I$ is illite, $K$ is kaolinite, $G$ is gibbsite, $\mathrm{H}$ is halloysite, and $\mathrm{Q}$ is quartz. Halloysite peak intensity is greatest in the B22t horizon, and vermiculite and gibbsite peak intensities increase upward.

loessial origin or that the loess distribution is uneven and highly localized. Fine silt percentages do not correlate with ages of the Delmarva soils as determined from the geologic data. For example, Joynes Neck, $(60,000$ to 125,000 years old, site 2) and Nelsonia ( 140,000 to 220,000 years old, site 4) both show much greater percentages of fine silt than either Oyster $(60,000$ to 125,000 years old, site 3$)$ or Persimmon Point ( 140,000 to 220,000 years old, site 5). Fine silt in Joynes Neck and Nelsonia, if wind blown, is probably of local origin and not part of a widespread loess sheet composed dominantly of fine silt. The absence of a fine-silt blanket is consistent with Foss and others (1978) data that show no downwind sorting of silt or preferential transport of fine silt downwind from late Pleistocene sediments of Chesapeake Bay.

Neither does there appear to be any correlation between age of soil and percentage of fine to coarse clay or 


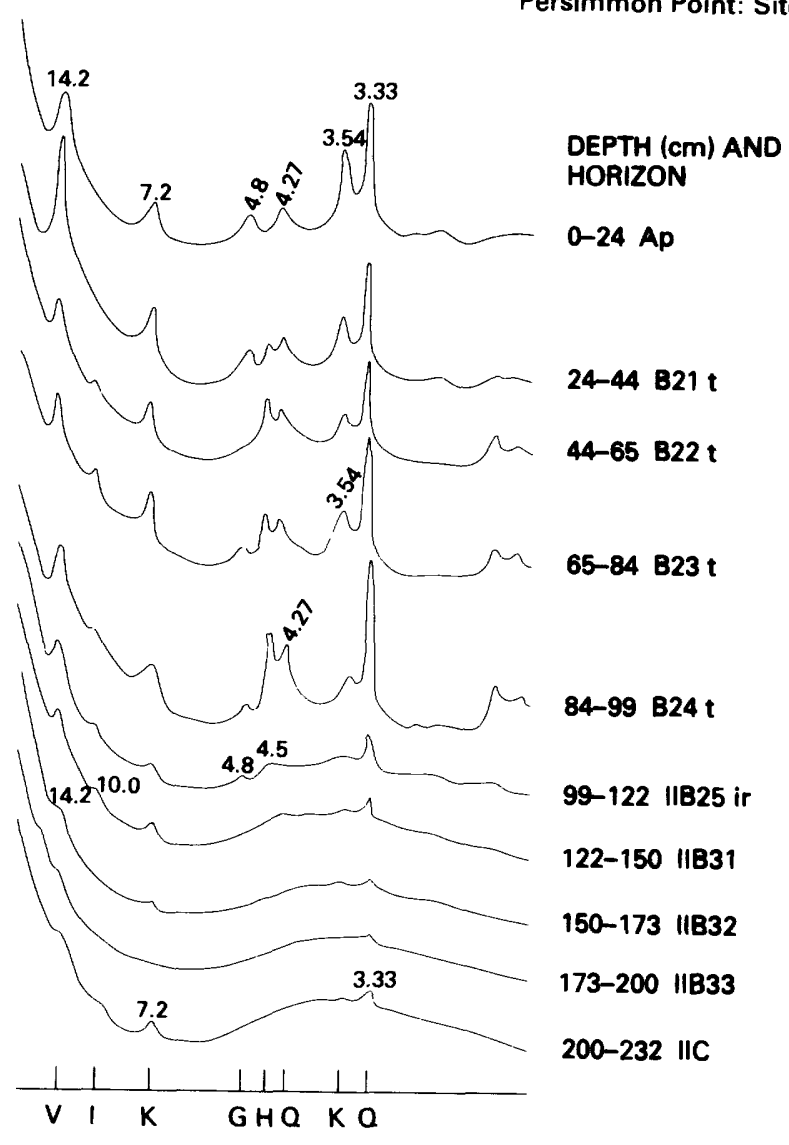

Figure 15. X-ray diffraction patterns for untreated $<2$ micron fractions from selected soil horizons, Persimmon Point, site 5 (exact location and field description in table 6A). Traces illustrated are of oriented, untreated clay. Peak spacings are in angstroms (A). Depths to middles of horizons are given in centimeters. $V$ is hydroxy-interlayered vermiculite, I is illite, $K$ is kaolinite, $\mathrm{G}$ is gibbsite, $\mathrm{H}$ is halloysite, and $\mathrm{Q}$ is quartz. Halloysite peak intensity is greatest below the B21t horizon, and vermiculite and gibbsite peak intensities increase above the B21t horizon.

clay mineralogy in these four pedons. The presence of significant amounts of halloysite in the Bt horizons of the Oyster and Persimmon pedons does suggest that there has been significant in-situ development of clay which, based upon the Norris Bridge pedon, would appear to be contemporaneous with development of fine silt (Pavich, unpub. data). The absence of halloysite does not, however, preclude in-situ development of clay and silt in the Joynes Neck and Nelsonia sites. Since the halloysite structure does not easily survive aeolian transport, the clay in the Oyster and Persimmon Point pedons is considered to be pedogenic in origin (formed in situ).

Aeolian silt and clay are probably significant contributors to at least two of the Delmarva sites. The best evidence for an aeolian origin for silt and clay is the correlation of the fine silt bulge with an HIV-rich epipedon in the younger
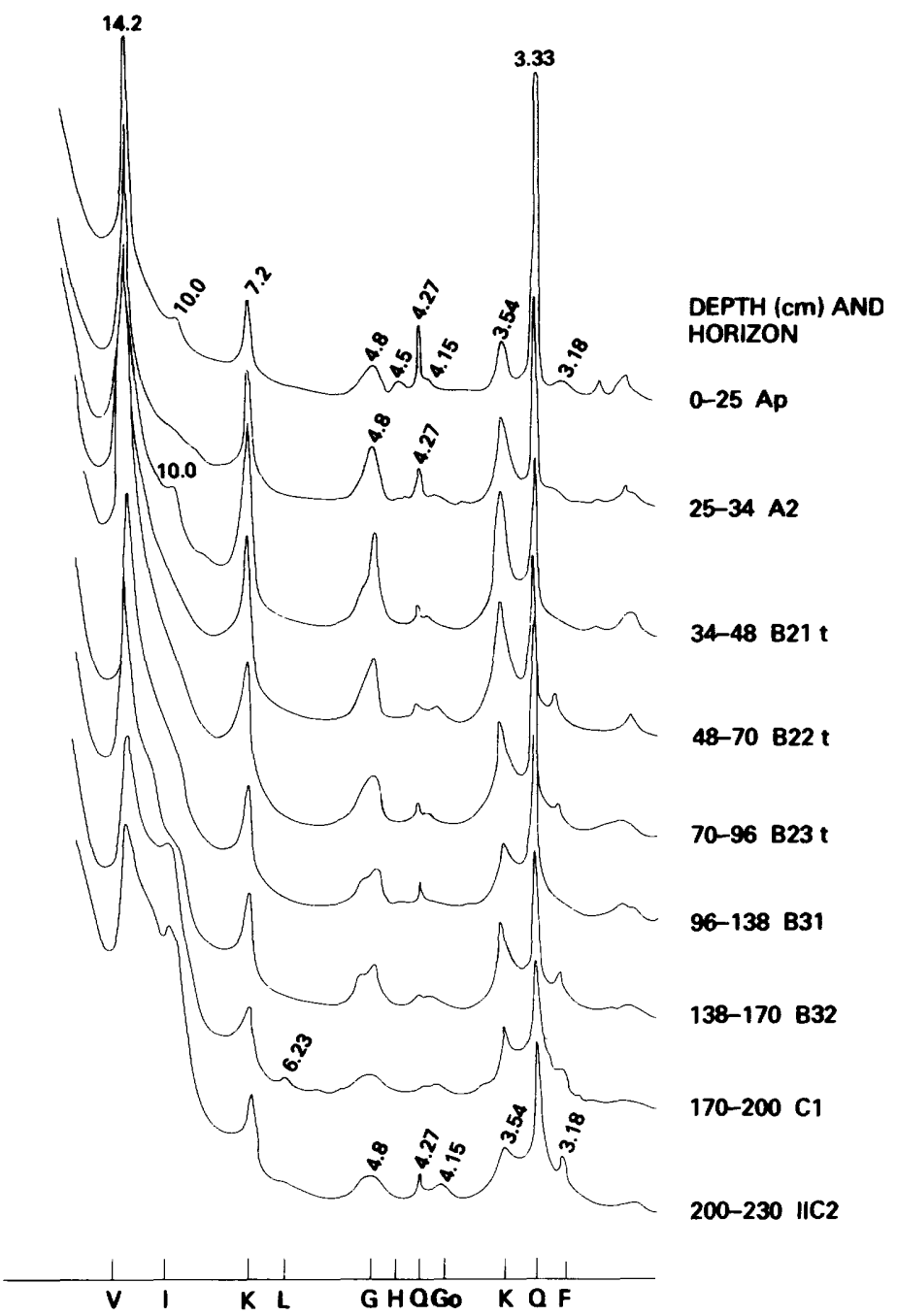

Figure 16. X-ray diffraction patterns for untreated $<2$ micron fractions from selected soil horizons, Norris Bridge, site 6 (exact location and field description in table 7A). Traces illustrated are of oriented, untreated clay. Peak spacings are in angstroms (A). Depths to middles of horizons are given in centimeters. $V$ is hydroxy-interlayered vermiculite, $I$ is illite, $K$ is kaolinite, $\mathrm{G}$ is gibbsite, $\mathrm{H}$ is halloysite, $\mathrm{L}$ is lepidocrosite, Go is goethite, $\mathrm{F}$ is $\mathrm{K}$-feldspar, and $\mathrm{Q}$ is quartz. Vermiculite peak intensity increases toward the surface and kaolinite peak intensity is strong throughout the profile.

soils. In Nelsonia and Joynes Neck, the strong aeolian input is indicated by fine silt and correlates with a high ratio of HIV/halloysite through the profile. Fine silt is less abundant and the ratio of HIV/halloysite is lower in Oyster and Persimmon Point soils, which also have higher ratios of fine to coarse clay. This complicates the interpretation of the genesis of those soils and points out the need for further study of the source and distance of transport of the loess.

Sites on the Rappahannock River show an increase of fine silt with age. In site 6 , the production of fine quartz silt from the breakdown of coarser grains has been documented 


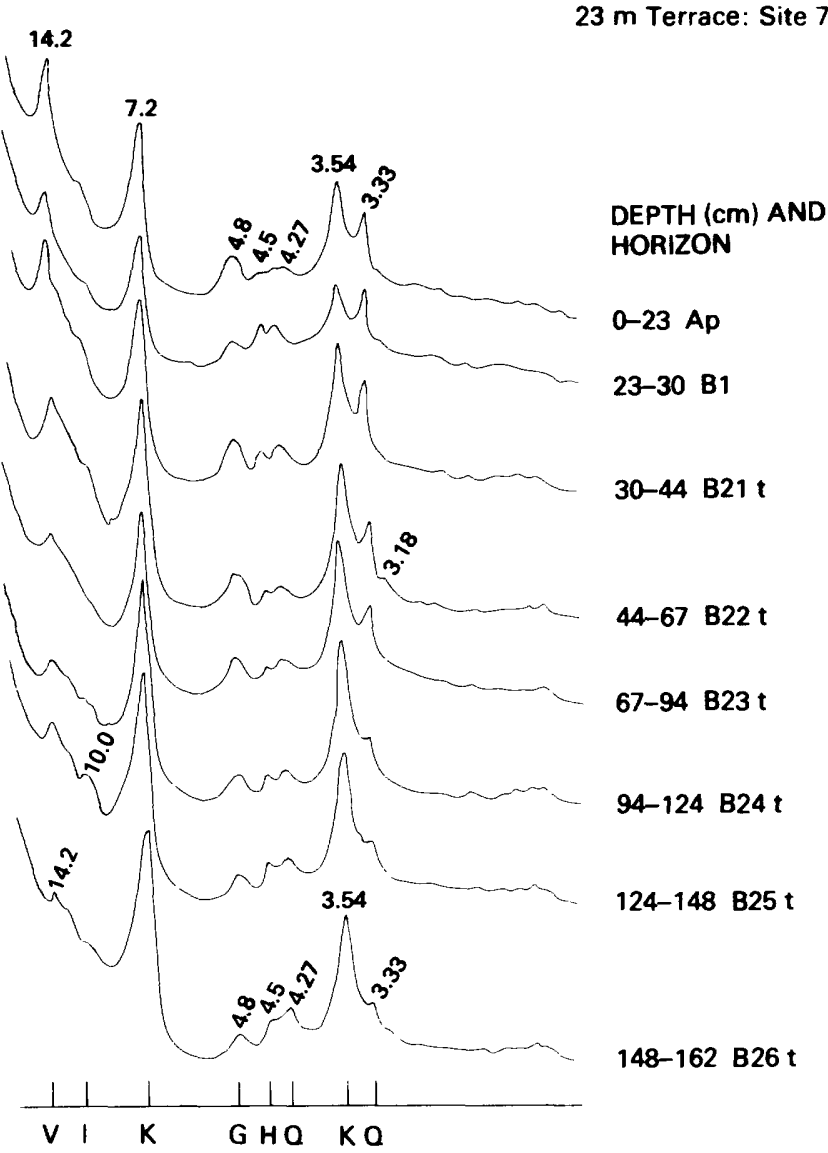

Figure 17. X-ray diffraction patterns for untreated $<2$ micron fractions from selected soil horizons, $23 \mathrm{~m}$ terrace, site 7 (exact location and field description in table $8 A$ ). Traces illustrated are of oriented, untreated clay. Peak spacings are in angstroms (A). Depths to middles of horizons are given in centimeters. $V$ is hydroxy-interlayered vermiculite, I is illite, $K$ is kaolinite, G is gibbsite, $H$ is halloysite, and $Q$ is quartz. Kaolinite is the dominant clay mineral in all horizons, and vermiculite peak intensity increases in the A horizons.

(Pavich, unpub. data). It appears likely that an in-situ pedogenic origin for fine silt is significant in the Rappahannock profiles. The large mass of clay found on the older Rappahannock terraces, the clay mineralogy, and the bulk chemistry cannot be explained by a simple accumulation of aeolian HIV and quartz through time. Addition of highly siliceous aeolian material through time would not produce a trend of increasing $\mathrm{Fe}_{2} \mathrm{O}_{3}+\mathrm{Al}_{2} \mathrm{O}_{3} / \mathrm{SiO}_{2}$, and the observed chemical trend is not consistent with an aeolian origin of silt and clay in these profiles (fig. 8).

From this study it is clear that there are two probable sources of fine silt in the A and B horizons of these pedons. Thus despite evidence for aeolian sediment transport (such as dunes and silt caps) care must be taken not to interpret all silty epipedons as loessial in origin. Scanning electron microscopy and oxygen isotope data (such as used by Sayin and Jackson, 1973) may help resolve the origin of the fine silt.

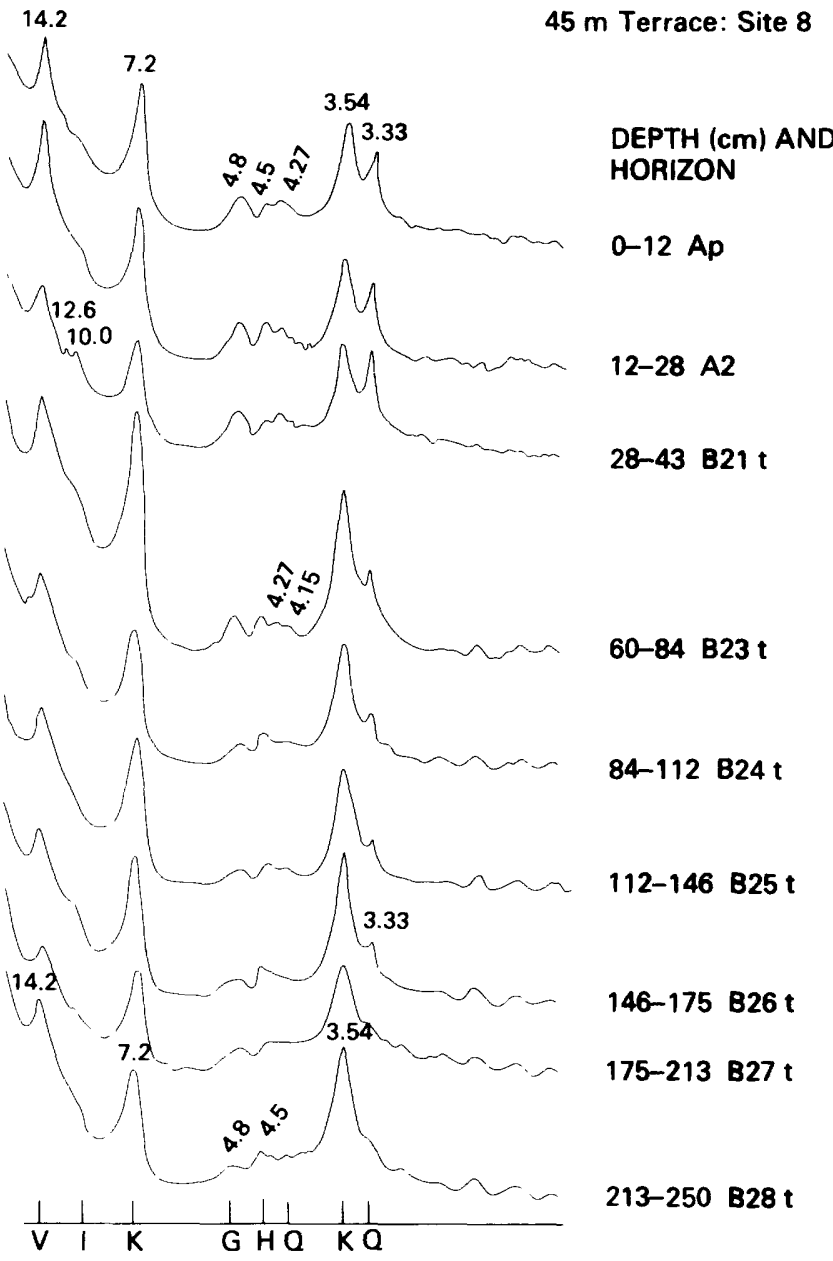

Figure 18. X-ray diffraction patterns for untreated $<2$ micron fractions from selected soil horizons, $45 \mathrm{~m}$ terrace, site 8 (exact location and field description in table 9A). Traces illustrated are of oriented, untreated clay. Peak spacings are in angstroms (A). Depths to middles of horizons are given in centimeters. $V$ is hydroxy-interlayered vermiculite, $I$ is illite, $K$ is kaolinite, G is gibbsite, $\mathrm{H}$ is halloysite, and $\mathrm{Q}$ is quartz. Kaolinite is the dominant clay mineral in all horizons, and vermiculite does not show an increase in intensity in the near-surface horizons.

\section{Age Relations}

As mapped, the marine deposits on the southern Delmarva Peninsula comprise a chronosequence of barrier, backbarrier, and (or) estuarine sediments deposited at successively lower sea levels. Alternatively, as suggested by Hack (1955), the Piedmont and Coastal Plain of Virginia and Maryland have been undergoing regional uplift since the late Tertiary, thereby resulting in an off-lap sequence of Pleistocene marine sediments. The terraces along the Rappahannock River also suggest either a progressive lowering of sea level or regional uplift during the Pliocene and Pleistocene. Preserved soil profiles on marine and fluvial terraces 


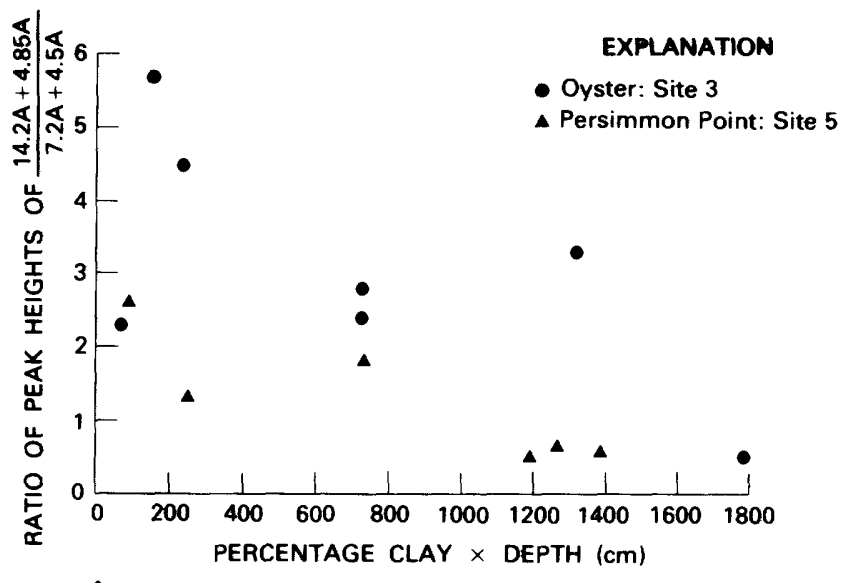

A

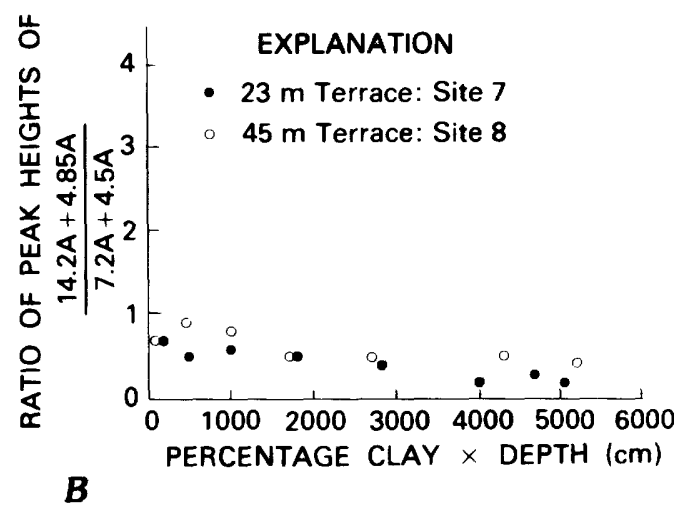

Figure 19. Ratio of peak heights of $14.2 \mathrm{~A}+4.85 \mathrm{~A} / 7.2 \mathrm{~A}+4.5$ A peaks plotted against [horizon depth $\times$ percent clay per horizon] for $(A)$ sites 3 and 5 , and $(B)$ sites 7 and 8 . Peak heights measured from untreated $X$-ray diffraction patterns, figures $13,15,17$, and 18 . Textural data from tables $4 B, 6 B$ $8 B$, and $9 B$.

in this landscape increase in degree of development with increase in altitude. The grossly similar grain-size distributions (tables $2 B$ through $9 B$ and figure 3 ) for soils on the various surfaces and the common source of parent material yield a chronosequence of soils ranging in age from about 30,000 to $>1.0$ ? m.y.

It is difficult to isolate certain physical characteristics such as soil color or thickness of solum (A and B horizons) from the chemical processes that produce them. However, plots of growth curves (changes of property over time) for physical and chemical characteristics (figs. 5 through 10) show similarities and divergences. The physical properties of redness, clay mass, and solum thickness suggest a step, or plateau, in growth curves at about 60,000 to 220,000 years and a subsequent increase in rate of development from 500,000 ? to $>1.0$ ? m.y.

A third-degree polynomial (least squares) equation fits the data for redness of the Bt horizons better than a linear equation because the standard error of the estimate of a linear regression is 33.7 , and this error is 0.8 for the thirddegree polynomial. The equation is

$$
Y=301.8-64.8(\ln X)^{2}-0.1(\ln X)^{3}
$$

where

$Y$ is redness and

$X$ is the natural log of age.

The inflection point of the curve is between 200,000 and 500,000 years. The data suggest, therefore, that the plateau at 60,000 to 220,000 years defines an upper limit of rapid soil development. Similar results are obtained by fitting equations to the other physical properties. The chemical property $\mathrm{Al}_{2} \mathrm{O}_{3}+\mathrm{Fe}_{2} \mathrm{O}_{3} / \mathrm{SiO}_{2}$ ratio does not have this plateau. These curves indicate that properties change with time but at different rates and that in combination they can be used to determine the age of a soil.

Birkeland $(1974$, p. 131) suggested hypothetical variations in several soil properties with time (fig. 20). His curves representing accumulation of organic carbon and clay are similar in that they both show steep positive slopes of rapid accumulation that level off to zero. The flat slopes represent a hypothetical stage of soil development during which no change in a particular soil property takes place. This can be considered to be a steady-state, or equilibrium, for that particular property. The plateau in the physical properties of the Maryland and Virginia Coastal Plain soils may indicate such steady states. However, after a certain period of little change, the properties again begin to change with time. The contrast of results of this study with those of others (Birkeland, 1974; Simonson, 1978) is possibly due to a lack of measurement of all properties of pedogenic origin in soils $1.0 ? \mathrm{~m}$.y. old or older. Evidence presented here, that soil properties do continue to change through time, is corroborated by studies by Harden and Marchand (1977), McFadden and others (1982), and Harden (1982).

\section{CONCLUSIONS}

Soils developed on surfaces ranging in age from 30,000 to 1.0 ? m.y. and underlain by texturally and mineralogically similar parent materials provide a means to study change of properties with age of surface. Physical properties of clay mass, redness, and solum thickness increase with time, except for a period of no change (steady state?) between 100,000 and several hundred thousand years. All physical properties studied show a dynamic nature, even in soils of ages greater than 1.0 ? m.y. Chemical properties such as the $\mathrm{Al}_{2} \mathrm{O}_{3}+\mathrm{Fe}_{2} \mathrm{O}_{3} / \mathrm{SiO}_{2}$ ratio appear to increase at a constant rate.

It is relatively easy to characterize the differences between the 30,000-year- and the 100,000- to 200,000year-old sola, the 200,000- and 500,00?-year-old sola, and the 500,000 ?- and 1.0 ?-m.y.-old sola. It is not easy to differentiate soils between the 60,000- and 200,000-year- 


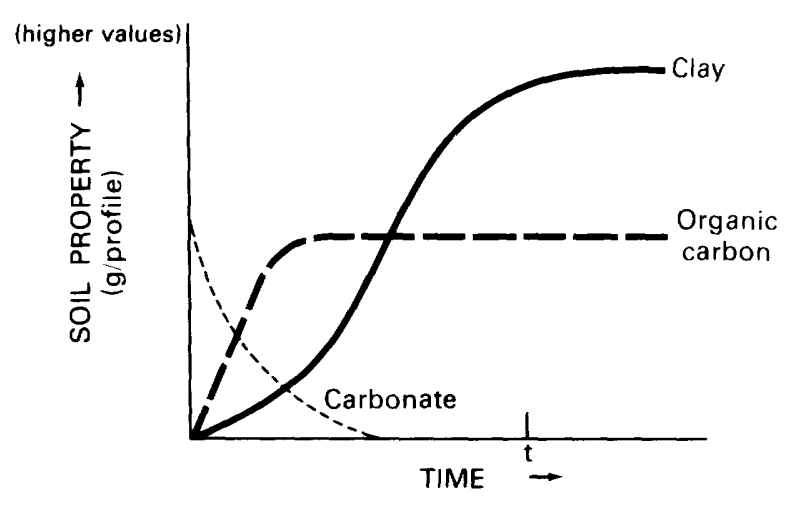

Figure 20. Plot from Birkeland (1974) that shows hypothetical variation in clay, organic carbon, and carbonate values in soils through time.

old range from the 30,000 -year-old soils, nor is it easy to differentiate soils that range in age between 60.000 and 200,000 years. Of the properties studied, the $\mathrm{Al}_{2} \mathrm{O}_{3}+\mathrm{Fe}_{2} \mathrm{O}_{3} /$ $\mathrm{SiO}_{2}$ ratio shows the clearest trend and may prove to be the most useful indicator for differentiating soils of this age. But many more soils developed in sediments 60,000 to 200,000 years old are needed if we expect to separate that time period into smaller units.

\section{ACKNOWLEDGMENTS}

We would like to express our appreciation to J.P. Owens, R.B. Mixon, and J.T.Hack of the U.S. Geological Survey, National Center, MS 926, Reston, VA 22092, and R.A. Daniels and Klaus Flach of the USDA Soil Conservation Service for their initiative in suggesting a cooperative project between the two agencies and for their encouragement throughout the study period. We also extend our thanks for the assistance of field personnel of the Soil Conservation Service in sampling the study profiles.

\section{REFERENCES CITED}

Barnheisel, R.I., and Rich, C.I., 1966, Preferential hydroxyaluminum interlayering in montmorillonite and vermiculite: Soil Science Society of America Proceeding, v. 30. p. 3539.

Birkeland, P.W., 1974, Pedology, weathering and geomorphological research: Oxford University Press, New York, N.Y., $285 \mathrm{p}$.

Bruce, R.R., and Whisler, F.D., 1973, Infiltration of water into layered field soils, in Hodas, A., and others, eds., Physical aspects of soil waters and salts in ecosystems, SpringerVerlag, New York, p. 77-90

Colman, S.M. 1983, Progressive changes in the morphology of fluvial terraces and scarps along the Rappahannock River, Virginia: Earth Science Processes and Landforms, v. 8, p. 201-212.
Daniels, R.B., and Gamble, E.E., 1978, Relations between stratigraphy, geomorphology, and soils in Coastal Plain areas of southeastern USA: Geoderma, v. 21, p. 1-65.

Daniels. R.B., Gamble, E.E., and Wheeler, W.H., 1978, Age of soil landscapes in the Coastal Plain of North Carolina: Soil Science Society of America Journal, v. 42, p. 98-105.

Douglas, L.A., 1977, Vermiculites, in Dixon, J.B., and Weed, S.B., eds., Minerals in soil environments: Soil Science Society of America, Madison, Wisconsin, p. 258-292.

Flanagan, F.J., 1976, Descriptions and analyses of eight new USGS rock standards: U.S. Geological Survey Professional Paper 840. 192 p.

Follmer, L.T., 1978, The Sangamon soil in its type area-a review, in Mahaney, W.C., ed., Quaternary soils, Geological Abstracts Ltd.: Norwich, p. 125-165.

Foss, J.E., Fanning, D.S., Miller, F.P., and Wagner, D.P., 1978, Loess deposits of the eastern shore of Maryland: Soil Science Society of America Journal, v. 42, p. 329-334.

Hack, J.T., 1955, Geology of the Brandywine area and origin of the upland of southern Maryland: U.S. Geological Survey Professional Paper 267-A, 43 p.

Harden, J.W., 1982, A quantitative index of soil development from field descriptions: examples from a chronosequence in central California: Geoderma, v. 28, p. 1-28.

Harden, J.W., and Marchand, D.E., 1977, The soil chronosequence of the Merced River area, in Singer M.H., ed., Soil development, geomorphology and Cenozoic history of the northeastern San Joaquin Valley and adjacent area, California: Guidebook for the Joint Field Session of the American Society of Agronomy, Soil Science Society of America, and Geological Society of America, Chapter VI, p. 22-38.

Karanthanasis, A.D., Adams, Fred, and Hajek, B.F., 1983, Stability relationships in kaolinite, gibbsite, and $\mathrm{Al}$ hydroxyinterlayered vermiculite soil systems: Soil Science Society of America Journal, v. 47, p. 1247-1251.

Lewis, G.C., Fossberg, M.A., Falen, A.L., and Miller, B.J., 1984, Identification of loess by particle size distribution using the Coulter Counter TAII: Soil Science, v. 137, p. 172-176.

McCartan, L., Owens, J.P., Blackwelder, B.W., Szaba, B.J., Belknap, D.F., Kriausakui, N., Mitterer, R.M., and Wehmiller, J.F., 1982, Comparison of amino acid racemization geochronology with lithostratigraphy, biostratigraphy, uranium-series coral dating, and magnetostratigraphy in the Atlantic Coastal Plain of the southeastern United States: Quaternary Research, v. 18, p. 337-359.

McFadden, L.O., Tinsley, J.C., and Bull, W.B., 1982, Late Quaternary pedogenesis and alluvial chronologies of the Los Angeles Basin and San Gabriel Mountains areas, southern California, in Tinsley, J.C., ed., Guidebook for the 78th Annual Meeting of the Cordilleran Section of the Geological Society of America, Anaheim, California, April 19-21, p. 1-27.

Mixon, R.B., 1985, Stratigraphic and geomorphic framework of Upper Cenozoic deposits in the southern Delmarva Peninsula, Virginia and Maryland: U.S. Geological Survey Professional Paper 1067-G, 60 p.

Mixon, R.B., Szabo, B.J., and Owens, J.P., 1982, Uranium-series dating of mollusks and corals, and age of Pleistocene deposits, Chesapeake Bay area, Virginia and Maryland: U.S. Geological Survey Professional Paper 1067-E, 41 p. 
Newell, W.L., 1985, Architecture of the Rappahannock Estuaryneotectonics in Virginia, in Morisawa, M., and Hack, J.T., eds., Tectonic Geomorphology, proceedings volume of the Fifteenth Annual Geomorphology Symposia Series, held at Binghamton, N.Y., September 28-29, 1984: Allen and Unwin.

Owens, J.P., and Denny, C.S., 1979, Upper Cenozoic deposits of the Delmarva Peninsula, Maryland and Delaware: U.S. Geological Survey Professional Paper 1067-A, 28 p.

Owens, J.P., and Minard, J.P., 1979, Upper Cenozoic sediments of the lower Delaware Valley and the northern Delmarva Peninsula, New Jersey, Pennsylvania, Delaware, and Maryland: U.S. Geological Survey Professional Paper 1067-D, 47 p.

Rich, C.I., 1968, Hydroxy interlayers in expansable layer silicates: Clays and Clay Minerals, v. 16, p. 15-30.

Ruhe, R.V., 1969, Quaternary landscapes in Iowa: Iowa University Press, Ames, Iowa, 255 p.

Sayin, Mahmut, and Jackson, M.L., 1973, Scanning electron microscopy of cherts in relation to the oxygen isotopic variation of soil quartz: Clays and Clay Minerals, v. 23, p. 365-368.
Simonson, R.W., 1978, A multiple process model of soil genesis, in Mahaney, W.C., ed., Quaternary soils, Geological Abstracts Limited: Norwich, p. 1-26.

1982, Loess in soils of Delaware, Maryland and Northeastern Virginia: Soil Science, v. 133, p. 167-178.

Soil Survey Staff, 1951, Soil Survey Manual, U.S. Department of Agriculture, Bureau of Plant Industry, Soils, and Agricultural Engineering Handbook No. 18: U.S. Government Printing Office, Washington, D.C., 503 p.

1972, Soil Survey investigations report no. 1: Soil Survey laboratory methods and procedures for collecting samples: USDA, Soil Conservation Service, U.S. Government Printing Office, Washington, D.C, 63 p.

1975, Soil taxonomy: USDA Soil Conservation Service, Agriculture Handbook No. 436, U.S. Government Printing Office, Washington, D.C. 754 p.

Thorp, J., and Smith, G.D., 1949, Higher categories of soil classification: Soil Science, v. 67, p. 117-126. 


\section{Tables 1-9}


Table 1. Analytical methods and units of expression for analyses conducted at the Soil Conservation Service, National Soil Survey Laboratory, Lincoln, Nebraska

\begin{tabular}{|c|c|c|}
\hline Analysis & Method code ${ }^{1}$ & Unit of expression \\
\hline Particle size & $--3 \mathrm{Al}$ & $\begin{array}{l}\text { weight percent }<2 \mathrm{~mm} \\
\text { material }\end{array}$ \\
\hline Organic carbon & .. $6 \mathrm{AlC}$ & $\begin{array}{l}\text { weight percent }<2 \mathrm{~mm} \\
\text { material }\end{array}$ \\
\hline Dithionite-citrate & $6 \mathrm{C} 2 \mathrm{~A}$ & $\begin{array}{l}\text { weight percent }<2 \mathrm{~mm} \\
\text { material }\end{array}$ \\
\hline Iron $\ldots \ldots$ & $\ldots 6 \mathrm{C} 2 \mathrm{~B}$ & $\begin{array}{l}\text { weight percent }<2 \mathrm{~mm} \\
\text { material }\end{array}$ \\
\hline Aluminum & $\ldots 6 \mathrm{G} 7 \mathrm{~A}$ & $\begin{array}{l}\text { weight percent }<2 \mathrm{~mm} \\
\text { material }\end{array}$ \\
\hline Manganese & -. $6 \mathrm{D} 2 \mathrm{~A}$ & $\begin{array}{l}\text { weight percent }<2 \mathrm{~mm} \\
\text { material }\end{array}$ \\
\hline Bulk density .... & ... 4A1D & $\mathrm{g} / \mathrm{cm}^{3}<2 \mathrm{~mm}$ material \\
\hline $\mathrm{COLE}^{2} \ldots \ldots$ & $\ldots 4$ DI & $\mathrm{cm} / \mathrm{cm}$ whole soil \\
\hline 15-bar tension & $\ldots 4 \mathrm{~B} 2 \mathrm{~A}$ & $\begin{array}{l}\text { weight percent }<2 \mathrm{~mm} \\
\text { material }\end{array}$ \\
\hline $\mathrm{WRD}^{3} \quad \ldots \ldots$ & $\ldots 4 \mathrm{Cl}$ & $\mathrm{cm} / \mathrm{cm}$ whole soil \\
\hline Extractable bases & $\ldots 5 \mathrm{~B} 5 \mathrm{~A}$ & $\begin{array}{l}\mathrm{meq} / 100 \mathrm{~g}<2 \mathrm{~mm} \\
\text { material }\end{array}$ \\
\hline \multicolumn{3}{|l|}{ CEC } \\
\hline Sum of catio & $\ldots 5 \mathrm{~A} 3 \mathrm{~A}$ & $\begin{array}{l}\mathrm{meq} / 100 \mathrm{~g}<2 \mathrm{~mm} \\
\text { material }\end{array}$ \\
\hline $\mathrm{NH}_{4} \mathrm{OAC}$ & - $5 \mathrm{~A} 8 \mathrm{~B}$ & $\begin{array}{l}\mathrm{meq} / 100 \mathrm{~g}<2 \mathrm{~mm} \\
\text { material }\end{array}$ \\
\hline $\mathrm{Al}+$ bases $^{4}$ & $-5 \mathrm{~A} 3 \mathrm{~B}$ & $\begin{array}{l}\mathrm{meq} / 100 \mathrm{~g}<2 \mathrm{~mm} \\
\text { material }\end{array}$ \\
\hline \multicolumn{3}{|l|}{ Base saturation } \\
\hline Sum of catio & $\ldots 5 C 3$ & percent \\
\hline $\mathrm{NH}_{4} \mathrm{OAC}$ & $\ldots 5 \mathrm{Cl}$ & percent \\
\hline \multicolumn{3}{|l|}{$\mathrm{pH}$} \\
\hline $\mathrm{CaCl}_{2} \ldots$ & $--8 \mathrm{CIE}$ & negative $\log _{10}$ \\
\hline $\mathrm{H}_{2} \mathrm{O}$ & $-.8 \mathrm{C} 1 \mathrm{~A}$ & negative $\log _{10}$ \\
\hline
\end{tabular}

${ }^{1}$ Method codes from Soil Survey Staff (1972)

${ }^{2}$ Coefficient of linear extensibility

${ }^{3}$ Water-retention difference

${ }^{4}$ Aluminum precipitates from solution at $\mathrm{pH} 4.5$ to 4.8 . For $\mathrm{pH} \geq 5$, extractable aluminum is not measured. 
Table 2A. Description of physical characteristics of soil horizons at site 1, Eastern Neck Island, 28,000 years B.P.

[Eastern Neck Island is on the west side of the Delmarva Peninsula, $7 \mathrm{~km}$ north of U.S. Highway 50 bridge in Kent County, Maryland (fig. 1). The parent material is quartzose sand and silt of the Kent Island Formation. Surface elevations on Eastern Neck Island range from 3 to $7 \mathrm{~m}$. Our study site on the island is the only study locality without a detailed pedon description. Vegetation at the site is dominantly grass with a mixed hardwood forest only a few meters distant; the pit was approximately $18 \mathrm{~m}$ from the shore $\left(39^{\circ} 59^{\prime} 30^{\prime \prime} \mathrm{N}\right.$. lat, $75^{\circ} 59^{\prime} 15^{\prime \prime} \mathrm{W}$. long. $6 \mathrm{~m}$ MSL elevation, Langford Creek $7 \mathrm{l} / 2 \mathrm{~min}$. topographic quadrangle). The amount of aerosol contribution, if any. at this locality is undetermined, but a loess cap is indicated by textural analysis (Foss and others, 1978) and mineralogy. Further investigations are in progress. Only a general profile description was made at this locality, but it agrees with the mapped series]

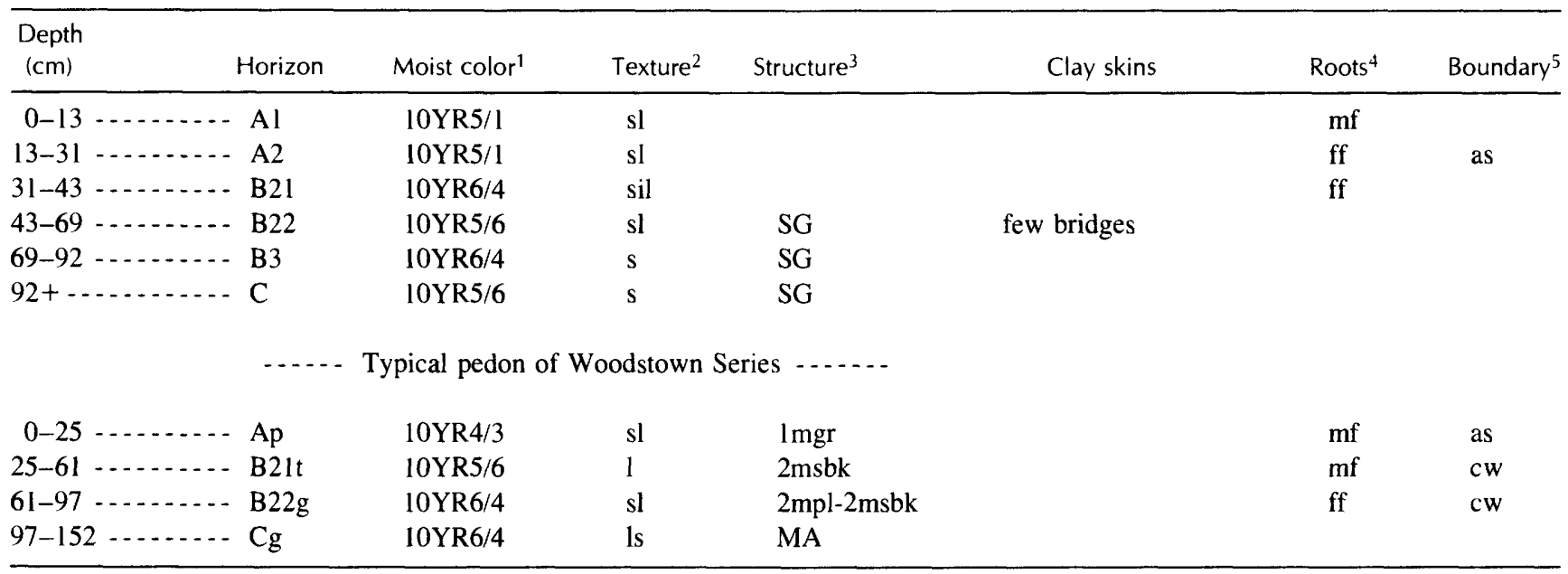

${ }^{1}$ Color: Munsell notation

${ }^{2}$ Texture: $l=$ loam, sil=silty loam, $s \mathrm{l}=$ sandy loam, $\mathrm{l}=$ =loamy sand, $\mathrm{s}=$ sand, $\mathrm{g}=$ gravel

${ }^{3}$ Structure: $\mathrm{l}=$ weak, $2=$ moderate, $\mathrm{m}=$ =medium, $\mathrm{gr}=$ granular, $\mathrm{sbk}=$ subangular blocky, $\mathrm{pl}=$ platy, $\mathrm{SG}=$ single grain, $\mathrm{MA}=\mathrm{massive}$

${ }^{4}$ Roots: $\mathrm{ff}=$ few fine, $\mathrm{mf}=$ many fine

${ }^{5}$ Boundary: $\mathrm{cs}=$ clear smooth, as = abrupt smooth, $\mathrm{cw}=$ clear wavy, $\mathrm{gs}=$ gradual smooth

Table 2B. Textural analyses of soil horizons at site 1, Eastern Neck Island $[<$, less than; F, fine; C, coarse; VF, very fine; VC, very coarse; $M$, medium; TR, trace; grain sizes in millimeters]

\begin{tabular}{|c|c|c|c|c|c|c|c|c|c|c|c|}
\hline \multirow[b]{2}{*}{$\begin{array}{l}\text { Depth } \\
(\mathrm{cm})\end{array}$} & \multirow[b]{2}{*}{ Horizon } & \multicolumn{3}{|c|}{ Total } & \multicolumn{2}{|c|}{ Silt } & \multicolumn{5}{|c|}{ Sand } \\
\hline & & $\begin{array}{l}\text { Clay } \\
<.002\end{array}$ & $\begin{array}{c}\text { Silt } \\
.002-.05\end{array}$ & $\begin{array}{l}\text { Sand } \\
.05-2\end{array}$ & $\begin{array}{c}\mathrm{F} \\
.002-.02\end{array}$ & $\begin{array}{c}\mathrm{C} \\
.02-.05\end{array}$ & $\begin{array}{c}V F \\
.05-.10\end{array}$ & $\begin{array}{c}F \\
.10-.25\end{array}$ & $\begin{array}{c}M \\
.25-.50\end{array}$ & $\begin{array}{c}C \\
.5-1\end{array}$ & $\begin{array}{l}\text { VC } \\
1-2\end{array}$ \\
\hline \multicolumn{2}{|c|}{$0-13 \ldots \mathrm{Al}$} & 5.8 & 32.5 & 61.7 & 15.4 & 17.1 & 13.9 & 29.5 & 15.4 & 1.8 & 0.1 \\
\hline \multicolumn{2}{|c|}{$13-30 \ldots A 2$} & 5.3 & 34.2 & 60.5 & 16.8 & 17.4 & 24.8 & 28.4 & 15.1 & 2.0 & .2 \\
\hline \multicolumn{2}{|c|}{$30-43 \ldots B 21$} & 4.4 & 34.9 & 60.7 & 17.8 & 17.1 & 15.1 & 30.8 & 13.4 & 1.3 & .1 \\
\hline \multicolumn{2}{|c|}{$92+\ldots .-C$} & 10.5 & 27.5 & 62.0 & 7.7 & 19.8 & 18.4 & 28.7 & 13.8 & 1.1 & TR \\
\hline
\end{tabular}


Table 2C. Weight percent of oxides in soil horizons at site 1, Eastern Neck Island

\begin{tabular}{|c|c|c|c|c|}
\hline \multirow[b]{2}{*}{ Oxide } & \multicolumn{4}{|c|}{ Horizon, depth $(\mathrm{cm})$} \\
\hline & $\begin{array}{c}B 21 \\
30-43\end{array}$ & $\begin{array}{c}\text { B22 } \\
43-69\end{array}$ & $\begin{array}{c}B 3^{1} \\
69-91\end{array}$ & $\begin{array}{c}C^{1} \\
91+\end{array}$ \\
\hline $\mathrm{SiO}_{2} \ldots 90.48$ & 91.94 & 92.63 & 90.00 & 89.20 \\
\hline $\mathrm{Al}_{2} \mathrm{O}_{3} \ldots 4.81$ & 4.67 & 4.67 & 3.40 & 5.30 \\
\hline $\mathrm{Fe}_{2} \mathrm{O}_{3} \ldots 19$ & 1.15 & 1.42 & 0.65 & 1.43 \\
\hline $\mathrm{CaO} \ldots 0.19$ & 0.18 & 0.14 & .20 & 0.20 \\
\hline $\mathrm{K}_{2} \mathrm{O}$ & .84 & .54 & .80 & .80 \\
\hline $\mathrm{TiO}_{2} \ldots . .75$ & .68 & .55 & .66 & .66 \\
\hline $\mathrm{P}_{2} \mathrm{O}_{5} \ldots$ & .08 & .06 & .08 & .08 \\
\hline MnO $\ldots 3$ & .02 & .01 & .02 & .02 \\
\hline Total $\ldots 98.4$ & 99.6 & 100.0 & 95.8 & 97.7 \\
\hline $\mathrm{Fe}_{2} \mathrm{O}_{3}+\mathrm{Al}_{2} \mathrm{O}_{3} / \mathrm{SiO}_{2} \ldots .6$ & 6.3 & 6.6 & 4.6 & 7.5 \\
\hline
\end{tabular}

${ }^{1}$ Samples mixed with standard basalt to lower the $\mathrm{SiO}_{2}$ concentration

Table 2D. Analyses of extractable Fe, Al, oxalates, and $\mathrm{pH}$ of soil horizons at site 1, Eastern Neck Island [TR means trace; no entry means not analyzed]

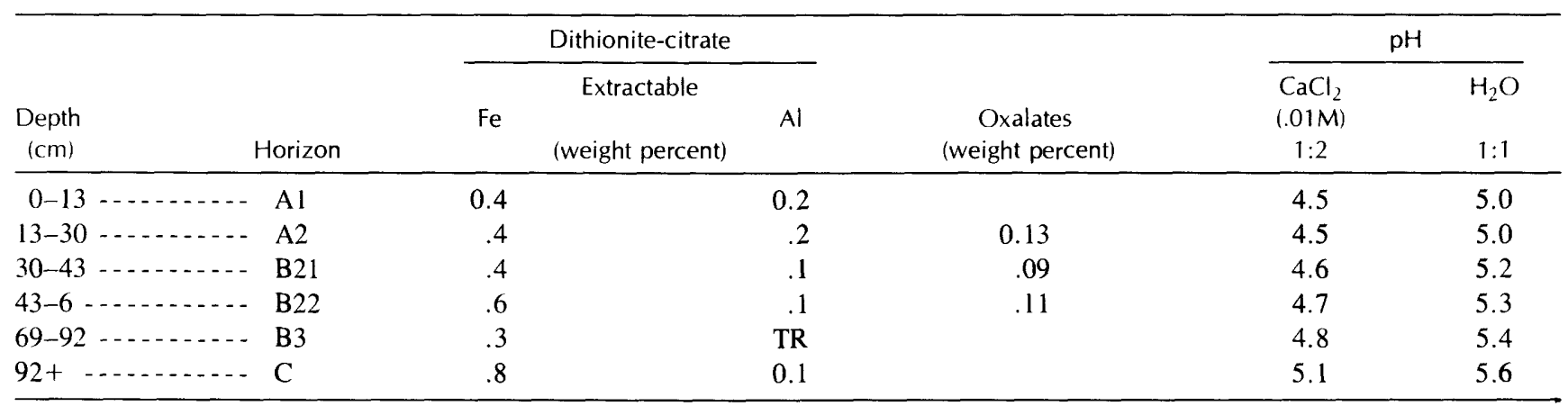

Table 3A. Description of physical characteristics of soil horizons at site 2, Joynes Neck

[The Joynes Neck soil is developed on a gently sloping, moderately dissected plane interpreted to be a part of the shallow shelf immediately adjacent to shore during Nassawadox time 60,000-125,000 years B.P. (fig. 1). The study site is located $12.3 \mathrm{~km}$ northeast of Accomack in Accomack County, Va. $\left(37^{\circ} 50^{\prime} \mathrm{N}\right.$. lat, $75^{\circ} 31^{\prime} \mathrm{W}$. long, $5 \mathrm{~m}$ MSL elevation, Bloxom $71 / 2 \mathrm{~min}$. topographic quadrangle). The texture of the sediments in the upper $200 \mathrm{~cm}$ at Joynes Neck is similar to those at Oyster, which are considered to be equivalent in age. The parent material at Joynes Neck is $6 \mathrm{~m}$ of interbedded gravelly and very coarse pebbly clean quartz sand grading upward into medium- to fine-grained quartz sand in the upper $2 \mathrm{~m}$ ]

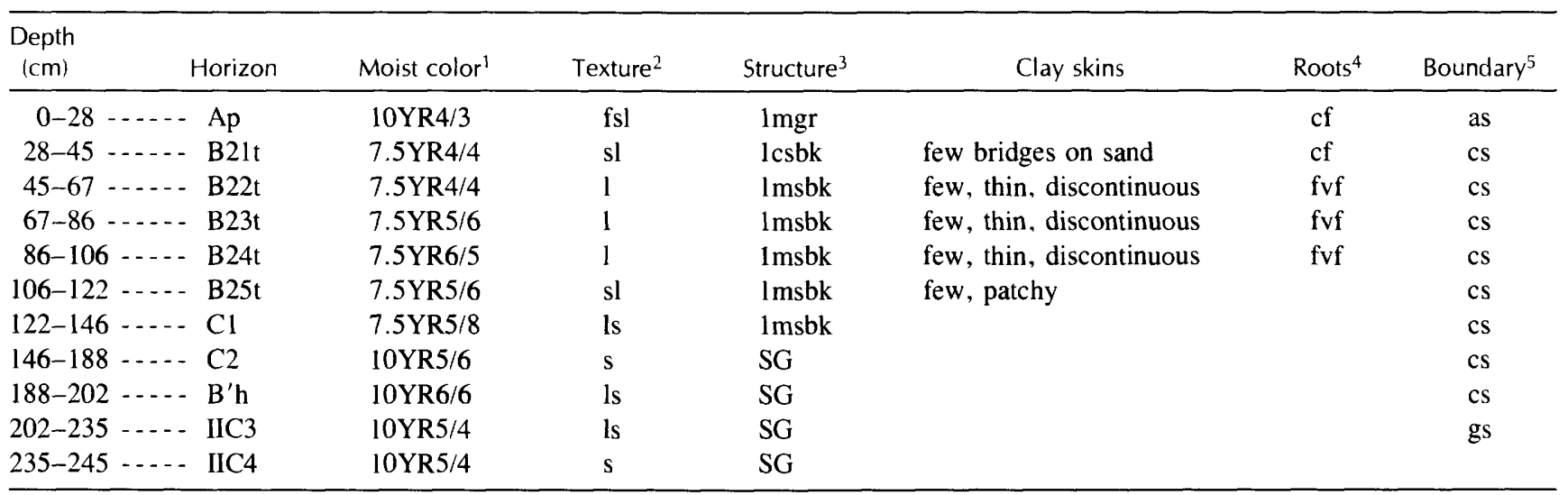

'Color: Munsell notation

${ }^{2}$ Texture: $l=$ loam, $\mathrm{fs}=$ =fine sandy loam, $\mathrm{sl}=$ sandy loam, $\mathrm{l}=$ =loamy sand, $\mathrm{s}=$ sand, $\mathrm{g}=$ gravel

${ }^{3}$ Structure: $1=$ weak, $2=$ moderate, $m=$ medium, $c=$ coarse, $g r=$ granular, sbk=subangular blocky, $p=p l a t y, S G=$ single grain

${ }^{4}$ Roots: $\mathrm{ff}=$ few fine, $\mathrm{mf}=$ many fine, $\mathrm{cf}=$ common fine, $\mathrm{fvf}=$ few very fine

${ }^{5}$ Boundary: $\mathrm{cs}=$ clear smooth, as $=$ abrupt smooth, $\mathrm{cw}=$ clear wavy, $\mathrm{gs}=$ gradual smooth 
Table 3B. Textural Analyses of soil horizons at site 2, Joynes Neck

[Sampled as: fine-loamy, mixed, thermic Typic Hapludult; <, less than: F, fine; C, coarse; VF, very fine; VC, very coarse; M, medium; --, not detected; grain sizes in millimeters]

\begin{tabular}{|c|c|c|c|c|c|c|c|c|c|c|c|}
\hline $\begin{array}{c}\text { Depth } \\
(\mathrm{cm})\end{array}$ & \multicolumn{3}{|c|}{ Total } & $\frac{\text { Clay }}{\mathrm{F}}$ & \multicolumn{2}{|c|}{ Silt } & \multicolumn{5}{|c|}{ Sand } \\
\hline $28-45---B 21 t$ & 15.9 & 38.9 & 45.2 & 5.7 & 29.8 & 9.1 & 2.3 & 15.4 & 20.1 & 6.1 & 1.3 \\
\hline $45-67-\ldots-B 22 t$ & 17.1 & 40.1 & 42.8 & 5.3 & 30.9 & 9.2 & 2.2 & 14.6 & 19.2 & 5.8 & 1.0 \\
\hline $67-86 \ldots B 23 t$ & 17.5 & 40.3 & 42.2 & 3.7 & 29.7 & 10.6 & 2.1 & 14.3 & 19.4 & 5.6 & 0.8 \\
\hline $106-122 \ldots-B 25 t$ & 12.1 & 15.4 & 72.5 & 5.3 & 12.1 & 3.3 & 3.4 & 25.3 & 33.7 & 7.8 & 2.3 \\
\hline $122-146---C 1$ & 6.4 & 4.3 & 89.3 & 2.0 & 3.2 & 1.1 & 5.9 & 31.3 & 38.4 & 10.5 & 3.2 \\
\hline $146-188---C 2$ & 2.4 & 3.4 & 94.2 & -- & 2.4 & 1.0 & 3.7 & 24.0 & 44.2 & 17.9 & 4.4 \\
\hline $188-202---B^{\prime} h$ & 2.0 & 1.1 & 96.9 & 0.4 & 0.4 & 0.7 & 2.7 & 44.2 & 41.0 & 8.0 & 1.0 \\
\hline 202-235 - - IIC3 & 0.4 & 0.7 & 98.9 & -- & .4 & .3 & 9.1 & 57.5 & 21.3 & 6.0 & 5.0 \\
\hline
\end{tabular}

Table 3C. Weight percent of oxides in soil horizons at site 2, loynes Neck

[TR means trace]

\begin{tabular}{|c|c|c|c|c|c|c|c|c|c|c|c|}
\hline Oxide & \multicolumn{11}{|c|}{ Horizon, depth $(\mathrm{cm})$} \\
\hline $\mathrm{Al}_{2} \overline{\mathrm{O}}_{3} \ldots$ & 5.47 & 7.75 & 9.14 & 8.26 & 7.88 & 5.79 & 3.75 & 2.15 & 3.82 & 3.56 & 2.07 \\
\hline $\mathrm{Fe}_{2} \mathrm{O}_{3} \ldots \ldots$ & -1.79 & 2.94 & 2.77 & 3.24 & 3.44 & 2.87 & 1.78 & 1.05 & 0.35 & 0.12 & 0.27 \\
\hline $\mathrm{TiO}_{2} \ldots$ & -.87 & .97 & .87 & 1.01 & 1.00 & 1.10 & 1.24 & 1.14 & .39 & 0.31 & .15 \\
\hline $\mathrm{P}_{2} \mathrm{O}_{5} \ldots$ & -.13 & .039 & .091 & .046 & .039 & .034 & .068 & .032 & .016 & TR & TR \\
\hline $\mathrm{MnO}$ & .055 & .099 & .080 & .051 & .039 & .046 & .039 & .036 & .020 & TR & TR \\
\hline Total $\ldots$ & -96.8 & 96.1 & 96.4 & 96.3 & 96.4 & 98.48 & 101.7 & 101.1 & 99.8 & 97.9 & 101.0 \\
\hline $\mathrm{Fe}_{2} \mathrm{O}_{3}+\mathrm{Al}_{2} \mathrm{O}_{3} / \mathrm{SiO}_{2}-$ & -8.3 & 12.9 & 14.5 & 14.0 & 13.7 & 9.9 & 5.9 & 3.3 & 4.5 & 4.0 & 2.3 \\
\hline
\end{tabular}

Table 3D. Analyses of extractable Fe, Al, and Mn, oxalates, ratio clay, and bulk density of soil horizons at site 2, Joynes Neck [TR means trace: * means estimated: -- means not detected]

\begin{tabular}{|c|c|c|c|c|c|c|c|c|}
\hline \multirow{3}{*}{$\begin{array}{l}\text { Depth } \\
(\mathrm{cm})\end{array}$} & \multirow[b]{3}{*}{ Horizon } & \multicolumn{3}{|c|}{ Dithionite-citrate } & \multirow{3}{*}{$\begin{array}{c}\text { Oxalates } \\
\text { (weight percent) }\end{array}$} & & & \multirow{3}{*}{$\begin{array}{c}\text { Bulk density } \\
1 / 3 \text { bar }\end{array}$} \\
\hline & & \multirow{2}{*}{$\mathrm{Fe}$} & \multirow{2}{*}{$\begin{array}{c}\text { Extractable } \\
\mathrm{Al} \\
\text { (weight percent) }\end{array}$} & \multirow{2}{*}{$\mathrm{Mn}$} & & \multicolumn{2}{|c|}{ Ratio clay } & \\
\hline & & & & & & CEC & 15 bar & \\
\hline $0-28 \ldots$ & Ap & 0.6 & 0.2 & TR & - & 0.53 & 0.47 & 1.65 \\
\hline $28-45 \ldots$ & $\mathrm{B} 21 \mathrm{t}$ & 1.1 & .3 & 0.1 & -- & .28 & .41 & 1.62 \\
\hline $45-67 \ldots$ & $\mathrm{B} 22 \mathrm{t}$ & 1.2 & .3 & TR & 0.12 & .28 & .39 & 1.48 \\
\hline $67-86 \ldots$ & $\mathrm{B} 23 \mathrm{t}$ & 1.2 & .2 & TR & .15 & .30 & .40 & 1.61 \\
\hline $86-106-\ldots$ & $\mathrm{B} 24 \mathrm{t}$ & 1.2 & .2 & TR & -- & .32 & .41 & 1.72 \\
\hline $106-122 \ldots$ & $\mathrm{B} 25 \mathrm{t}$ & 1.1 & .2 & TR & -- & .30 & .44 & 1.67 \\
\hline $122-146 \ldots$ & $\mathrm{C} 1$ & .5 & .1 & TR & .10 & .23 & .44 & 1.50 \\
\hline $146-188-\ldots$ & $\mathrm{C} 2$ & .2 & TR & TR & -- & .21 & .54 & $1.60 *$ \\
\hline $188-202 \ldots \ldots$ & $B^{\prime} h$ & .2 & .2 & TR & -- & .40 & .90 & $1.70^{*}$ \\
\hline $202-235 \ldots \ldots$ & IIC3 & .1 & .1 & TR & - & .25 & 2.00 & $1.70 *$ \\
\hline $235-245 \ldots$ & IIC4 & .2 & .1 & TR & -- & - & -- & $1.70 *$ \\
\hline
\end{tabular}


Table 3E. Analyses of extractable bases, extractable Al, cation exchange capacity (CEC), Al saturation, and pH for soil horizons at site 2, Joynes Neck

[-- means not detected; no entry means not analyzed; TR means trace]

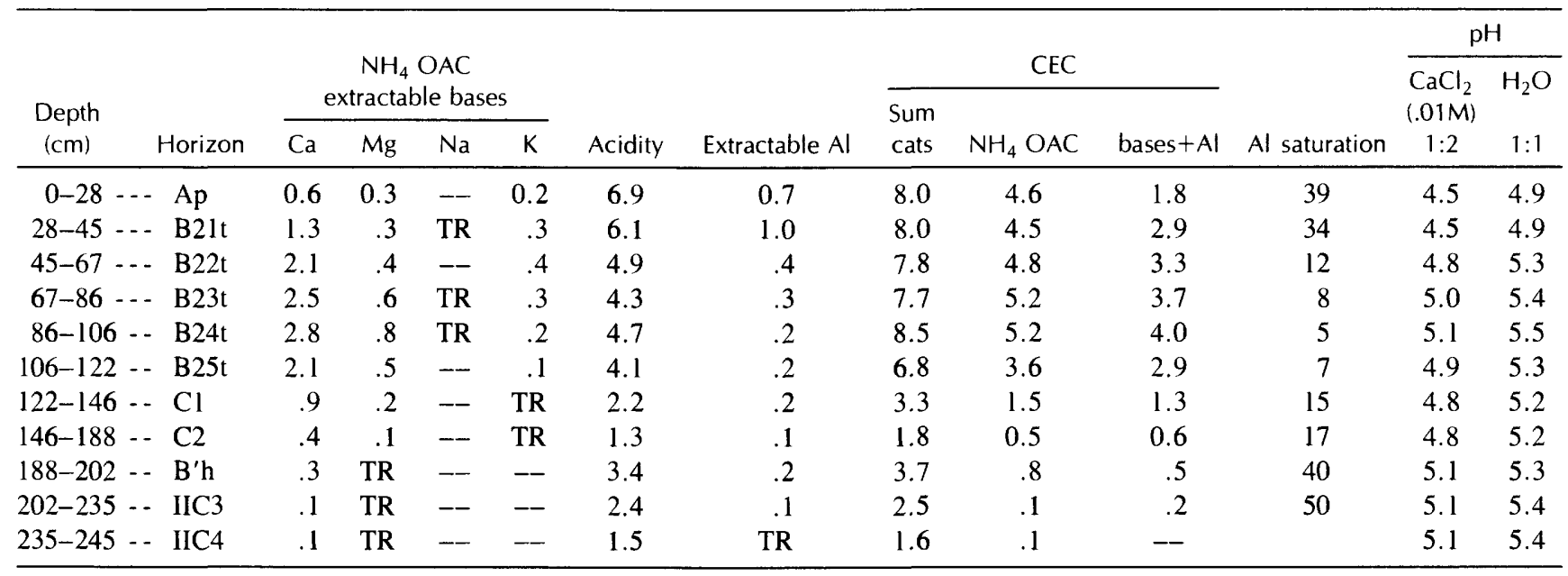

Table 4A. Description of physical characteristics of soil horizons at site 3, Oyster

[The study site at Oyster (fig. 1) is located $9.6 \mathrm{~km}$ south of Eastville, Northhampton County, Va. $\left(37^{\circ} 17^{\prime} \mathrm{N}\right.$. lat, $75^{\circ} 56^{\prime} \mathrm{W}$. long, $10 \mathrm{~m}$ MSL elevation, Cheriton $71 / 2 \mathrm{~min}$. topographic quadrangle). The soil at Oyster is developed in cross-bedded quartz barrier sands and gravels associated with a Nassawodox age (60,000-125,000 years B.P.) barrier. The solum and weathering profile are exposed in an abandoned quarry just north of Cobb Mill Creek ]

\begin{tabular}{|c|c|c|c|c|c|c|}
\hline $\begin{array}{l}\text { Depth } \\
(\mathrm{cm})\end{array}$ & Moist color ${ }^{1}$ & Texture $^{2}$ & Structure $^{3}$ & Clay skins & Roots $^{4}$ & Boundary 5 \\
\hline $0-27 \ldots \ldots$ Ap & $10 Y R 4 / 3$ & sl & $1 \mathrm{fgr}$ & & $\mathrm{ff}$ & as \\
\hline $27-50 \ldots \ldots$ B21t & $7.5 \mathrm{YR} 5 / 6$ & 1 & $1 \mathrm{msbk}$ & few, thin, patchy & fvf & gs \\
\hline $50-70 \ldots \ldots$ B22t & 7.5 YR $5 / 6$ & 1 & $1 \mathrm{msbk}$ & few, thin, patchy & fvf & gs \\
\hline $70-117 \ldots B$ B23t & $7.5 Y R 5 / 6$ & 1 & lcsbk & few, thin, pathcy & fvf & gs \\
\hline $117-132 \ldots \ldots$ IIB24t & 7.5 YR $5 / 8$ & sl & lcsbk & & & gs \\
\hline $132-147 \ldots \ldots$ IIB25t & $7.5 Y R 5 / 8$ & $\mathrm{sl}$ & $1 \mathrm{csbk}$ & & & cs \\
\hline $147-175 \ldots \ldots$ IIB & 10YR5/6 & is & SG & & & \\
\hline $175-215 \ldots \ldots$ IIC & I0YR $8 / 3$ & $\mathrm{~s}$ & SG & & & \\
\hline
\end{tabular}

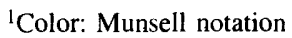

${ }^{2}$ Texture: $\mathrm{l}=$ loam, $\mathrm{sl}=$ sandy loam, $\mathrm{l}=$ =loamy sand, $\mathrm{s}=$ sand, $\mathrm{g}=$ gravel

${ }^{3}$ Structure: 1 =weak, 2 =moderate, $\mathrm{m}=$ medium, $\mathrm{gr}=$ granular, sbk=subangular blocky, $\mathrm{p}=$ platy, $\mathrm{SG}=$ single grain

${ }^{4}$ Roots: $\mathrm{ff}=$ few fine, $\mathrm{mf}=$ many fine, $\mathrm{fvf}=$ few very fine

${ }^{5}$ Boundary: $c s=$ clear smooth, as =abrupt smooth, $c w=$ clear wavy, $g s=$ gradual smooth

Table $4 \boldsymbol{B}$. Textural analyses of soil horizons at site 3, Oyster

[Sampled as: fine-loamy, mixed, thermic Typic Hapludult; <, less than; F, fine; C, coarse; VF, very fine; VC, very coarse; M, medium; -., not detected; grain sizes in millimeters]

\begin{tabular}{|c|c|c|c|c|c|c|c|c|c|c|c|c|}
\hline $\begin{array}{l}\text { Depth } \\
(\mathrm{cm})\end{array}$ & Horizon & \multicolumn{3}{|c|}{ Total } & 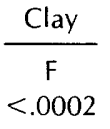 & \multicolumn{2}{|c|}{ Silt } & \multicolumn{5}{|c|}{ Sand } \\
\hline $27-50$ & $\mathrm{~B} 21 \mathrm{t}$ & 17.1 & 25.3 & 57.6 & 7.7 & 16.3 & 9.0 & 3.1 & 20.1 & 23.3 & 9.6 & 1.5 \\
\hline $50-70$ & $\mathrm{~B} 22 \mathrm{t}$ & 22.1 & 23.4 & 54.5 & 11.1 & 16.0 & 7.4 & 2.7 & 17.8 & 23.0 & 9.6 & 1.4 \\
\hline $70-117$ & $\mathrm{~B} 23 \mathrm{t}$ & 18.8 & 23.1 & 58.1 & 8.2 & 14.7 & 8.4 & 2.9 & 18.5 & 23.8 & 10.8 & 2.1 \\
\hline $132-147$ & IIB 25t & 5.2 & 3.5 & 91.3 & 2.0 & 2.0 & 1.5 & 3.8 & 26.4 & 24.2 & 18.8 & 18.1 \\
\hline $147-175$ & IIB3 & 1.6 & 1.4 & 97.0 & 0.8 & 1.2 & 0.2 & 3.5 & 36.3 & 33.4 & 16.3 & 7.5 \\
\hline $175-215$ & IIC & 0.8 & 0.5 & 98.7 & - & 0.4 & .1 & 7.2 & 43.4 & 33.5 & 10.1 & 4.5 \\
\hline
\end{tabular}


Table 4C. Weight percent of oxides in soil horizons at site 3, Oyster [TR means trace]

\begin{tabular}{|c|c|c|c|c|c|c|c|c|}
\hline \multirow[b]{2}{*}{ Oxide } & \multicolumn{8}{|c|}{ Horizon, depth $(\mathrm{cm})$} \\
\hline & $\begin{array}{l}A p \\
0-27\end{array}$ & $\begin{array}{c}\text { B21t } \\
27-50\end{array}$ & $\begin{array}{c}\text { B22t } \\
50-70\end{array}$ & $\begin{array}{c}\text { B23t } \\
70-117\end{array}$ & $\begin{array}{c}\text { IIB24t } \\
117-132\end{array}$ & $\begin{array}{c}\text { B25t } \\
132-147\end{array}$ & $\begin{array}{c}\text { IIB3 } \\
147-175\end{array}$ & $\begin{array}{c}\text { IIC } \\
175-215\end{array}$ \\
\hline $\mathrm{SiO}_{2}$ & 93.67 & 84.91 & 77.31 & 86.25 & 92.22 & 90.17 & 95.45 & 88.95 \\
\hline $\mathrm{Al}_{2} \mathrm{O}_{3}$ & 3.82 & 8.11 & 10.47 & 7.45 & 4.97 & 6.19 & 3.33 & 4.17 \\
\hline $\mathrm{Fe}_{2} \mathrm{O}_{3}$ & 0.81 & 2.28 & 3.53 & 3.26 & 1.08 & 0.61 & 0.02 & 0.01 \\
\hline $\mathrm{CaO}$ & .31 & 0.28 & 0.28 & 0.23 & 0.27 & .30 & .24 & .35 \\
\hline $\mathrm{K}_{2} \mathrm{O}$ & .95 & 1.05 & 1.03 & 1.11 & .84 & .91 & .97 & .96 \\
\hline $\mathrm{TiO}_{2}$ & .55 & .64 & .62 & 0.61 & .55 & .28 & .11 & .19 \\
\hline $\mathrm{P}_{2} \mathrm{O}_{5} \ldots$ & .10 & .027 & .05 & 0.039 & .016 & .031 & TR & TR \\
\hline $\mathrm{MnO}$ & .02 & .026 & .02 & 0.023 & .024 & .017 & $\mathrm{TR}$ & TR \\
\hline Total & 100.2 & 97.3 & $\overline{93.3}$ & 99.0 & 99.9 & 98.5 & 100.1 & 94.6 \\
\hline $\mathrm{Fe}_{2} \mathrm{O}_{3}+\mathrm{Al}_{2} \mathrm{O}_{3} / \mathrm{SiO}_{2} \ldots$ & -4.9 & 12.2 & 18.1 & 12.4 & 6.6 & 7.5 & 3.5 & 4.7 \\
\hline
\end{tabular}

Table 4D. Analyses of extractable Fe, Al, and $\mathrm{Mn}$, oxalates, ratio clay, and bulk density of soil horizons at site 3, Oyster [TR means trace; * means estimated: -- means not detected]

\begin{tabular}{|c|c|c|c|c|c|c|c|c|}
\hline \multirow{3}{*}{$\begin{array}{l}\text { Depth } \\
(\mathrm{cm})\end{array}$} & \multirow[b]{3}{*}{ Horizon } & \multicolumn{3}{|c|}{ Dithionite-citrate } & \multirow{3}{*}{$\begin{array}{c}\text { Oxalates } \\
\text { (weight percent) }\end{array}$} & & & \multirow{3}{*}{$\begin{array}{c}\text { Bulk densit } \\
1 / 3 \mathrm{bar}\end{array}$} \\
\hline & & \multirow{2}{*}{$\mathrm{Fe}$} & \multirow{2}{*}{$\begin{array}{c}\text { Extractable } \\
\mathrm{Al} \\
\text { (weight percent) }\end{array}$} & \multirow{2}{*}{$\mathrm{Mn}$} & & \multicolumn{2}{|c|}{ Ratio clay } & \\
\hline & & & & & & CEC & $15 \mathrm{bar}$ & \\
\hline $0-27$ & $-A p$ & 0.4 & 0.1 & -- & -- & 0.47 & 0.49 & 1.83 \\
\hline $27-50$ & $-\mathrm{B} 21 \mathrm{t}$ & 1.2 & .2 & TR & 0.07 & .27 & .39 & 1.79 \\
\hline $50-70$ & $-B 22 t$ & 1.8 & .3 & TR & .13 & .29 & .40 & 1.57 \\
\hline $70-117$ & - B23t & 1.6 & .3 & TR & .17 & .32 & .42 & 1.67 \\
\hline $117-132$ & - IlB24t & .6 & .1 & - & .04 & .25 & .42 & $1.80^{*}$ \\
\hline $132-147$ & - IIB25t & .5 & .1 & -- & -- & .21 & .48 & 1.81 \\
\hline $147-175$ & - IIB3 & .1 & .1 & -- & -- & .19 & 1.25 & $1.80^{*}$ \\
\hline $175-215$ & - IIC & .1 & TR & -- & -- & TR & 1.38 & $1.80^{*}$ \\
\hline
\end{tabular}

Table 4E. Analyses of extractable bases, extractable Al, cation exchange capacity (CEC), Al saturation, and pH for soil horizons at site 3 , Oyster

[-- means not detected: TR means trace]

\begin{tabular}{|c|c|c|c|c|c|c|c|c|c|c|c|c|c|}
\hline \multirow{3}{*}{$\begin{array}{l}\text { Depth } \\
(\mathrm{cm})\end{array}$} & \multirow[b]{3}{*}{ Horizon } & \multirow{2}{*}{\multicolumn{4}{|c|}{$\begin{array}{c}\mathrm{NH}_{4} \mathrm{OAC} \\
\text { extractable bases }\end{array}$}} & \multirow[b]{3}{*}{ Acidity } & \multirow{3}{*}{$\begin{array}{c}\text { Extractable } \\
\text { Al }\end{array}$} & \multirow{2}{*}{\multicolumn{3}{|c|}{ CEC }} & \multirow{3}{*}{$\begin{array}{c}\mathrm{Al} \\
\text { saturation }\end{array}$} & \multicolumn{2}{|c|}{$\mathrm{pH}$} \\
\hline & & & & & & & & & & & & \multirow{2}{*}{$\begin{array}{c}\mathrm{CaCl}_{2} \\
(.01 \mathrm{M}) \\
1: 2\end{array}$} & \multirow{2}{*}{$\begin{array}{r}\mathrm{H}_{2} \mathrm{O} \\
1: 1\end{array}$} \\
\hline & & $\mathrm{Ca}$ & $\mathrm{Mg}$ & $\mathrm{Na}$ & $\mathrm{K}$ & & & Sum cats & $\mathrm{NH}_{4} \mathrm{OAC}$ & bases $+\mathrm{Al}$ & & & \\
\hline \multicolumn{2}{|c|}{$0-27--$ Ap } & 1.7 & 0.7 & - & 0.4 & 2.4 & - & 5.2 & 2.5 & - & - & 5.8 & 6.2 \\
\hline \multicolumn{2}{|c|}{$27-50--\mathrm{B} 21 \mathrm{t}$} & 1.9 & .7 & -- & 0.4 & 3.5 & -- & 6.5 & 4.7 & - & -- & 5.4 & 6.0 \\
\hline \multicolumn{2}{|c|}{$50-70--B 22 t$} & 2.7 & 1.1 & - & 0.4 & 5.5 & 0.3 & 9.7 & 6.4 & 4.5 & 7 & 5.0 & 5.4 \\
\hline \multicolumn{2}{|c|}{$70-117--B 23 t$} & 2.6 & 1.1 & TR & 0.1 & 5.9 & - & 9.7 & 6.0 & -- & -- & 5.0 & 5.6 \\
\hline \multicolumn{2}{|c|}{ 117-132 - - IIB24t } & 1.1 & .5 & -- & 0.1 & 3.0 & -- & 4.7 & 1.8 & -- & - & 5.1 & 5.6 \\
\hline \multirow{2}{*}{\multicolumn{2}{|c|}{ 132-147 - - IIB25t }} & 0.8 & .4 & - & 0.1 & 2.4 & -- & 3.7 & 1.1 & -- & - & 5.2 & 5.7 \\
\hline \multirow{2}{*}{\multicolumn{2}{|c|}{$\begin{array}{l}147-175 \quad--11 B 3 \\
175-215 \quad-\text { IIC }\end{array}$}} & .4 & .2 & - & TR & 0.2 & - & 0.8 & 0.3 & -- & - & 5.4 & 5.8 \\
\hline & & .6 & .1 & - & TR & .8 & -- & 1.5 & TR & - & -- & 5.4 & 5.9 \\
\hline
\end{tabular}


Table 5A. Description of physical characteristics of soil horizons at site 4 , Nelsonia [The soil developed in medium to coarse barrier sands of the Omar Formation, 140,000-220,000 years in age. The site is $1.6 \mathrm{~km}$ south-southwest of Nelsonia near the junction of County Rd. 681 and U.S. Highway $13\left(37^{\circ} 46^{\prime} \mathrm{N}\right.$. lat , $75^{\circ} 36^{\prime} \mathrm{W}$. long, $15 \mathrm{~m} \mathrm{MSL}$ elevation, Bloxom $71 / 2 \mathrm{~min}$. topographic quadrangle) (fig. 1). It is possible that the Nelsonia site is on the rim of a Carolina Bay, which would make the land surface somewhat younger than that of the stratigraphically younger Nassawadox beds that also have well developed bays. The water table was intercepted at $167 \mathrm{~cm}$ l

\begin{tabular}{|c|c|c|c|c|c|c|}
\hline $\begin{array}{l}\text { Depth } \\
(\mathrm{cm})\end{array}$ & Moist color ${ }^{1}$ & Texture $^{2}$ & Structure $^{3}$ & Clay skins & Roots $^{4}$ & Boundary ${ }^{5}$ \\
\hline $0-12 \ldots-\ldots$ Ap & 10YR4/3 & fsl & $1 \mathrm{mgr}$ & & $\mathrm{cfm}$ & as \\
\hline $12-22-\ldots \mathrm{A} 12$ & $10 Y R 4 / 3$ & fsl & $1 \mathrm{msbk}$ & & $\mathrm{cfm}$ & cs \\
\hline $22-40 \ldots-B 21 t$ & $7.5 Y R 4 / 4$ & 1 & $1 \mathrm{msbk}$ & & ffm & gs \\
\hline $40-63-\ldots-B 22 t$ & 7.5YR4/4 & 1 & lmsbk & few, thin, discontinuous & $\mathrm{ffm}$ & gs \\
\hline $63-79-\cdots-B 23 t$ & $7.5 Y R 5 / 6$ & sI & $1 \mathrm{msbk}$ & & ffm & gs \\
\hline $79-95 \ldots \ldots 31$ & $7.5 \mathrm{YR} 5 / 6$ & sl & $1 \mathrm{msbk}$ & few, thin, discontinuous & ff & cs \\
\hline $95-121-\ldots-B 32 A^{\prime} 2$ & $10 Y R 5 / 6$ & Ifs & SG & & $\mathrm{ff}$ & cs \\
\hline $121-130 \ldots B^{\prime} 21$ hir & $10 Y R 5 / 6$ & Ifs & MA & & ff & cs \\
\hline $130-150 \ldots-B^{\prime} 22 \mathrm{hir}$ & $7.5 Y R 4 / 4$ & s & MA & & ff & cs \\
\hline $150-159 \ldots B^{\prime} 23 h$ & $7.5 Y R 4 / 4$ & ls & MA & & & cs \\
\hline $159-169-\ldots B^{\prime} 24 h$ & $5 Y R 3 / 2$ & Is & MA & & & \\
\hline
\end{tabular}

\footnotetext{
${ }^{1}$ Color: Munsell notation

${ }^{2}$ Texture: $\mathrm{l}=\mathrm{loam}, \mathrm{sl}=$ sandy loam, $\mathrm{fs}=$ fine sandy loam, $\mathrm{l}=$ =loamy sand, $\mathrm{s}=\mathrm{sand}, \mathrm{g}=$ gravel

${ }^{3}$ Structure: $\mathrm{l}=$ weak, $2=$ moderate, $\mathrm{m}=$ medium, $\mathrm{gr}=$ granular, $\mathrm{sbk}=$ subangular blocky, $\mathrm{p}=$ platy, $\mathrm{SG}=$ single grain, $\mathrm{MA}=$ massive

${ }^{4}$ Roots: $\mathrm{ff}=$ few fine, $\mathrm{mf}=$ many fine, $\mathrm{cfm}=$ common fine and medium, $\mathrm{ffm}=$ few fine and medium

${ }^{5}$ Boundary: $\mathrm{cs}=$ clear smooth, as = abrupt smooth, $\mathrm{cw}=$ clear wavy, gs $=$ gradual smooth
}

Table 5B. Textural analyses of soil horizons at site 4 , Nelsonia

[Sampled as: fine-loamy, mixed, thermic Typic Hapludult; <, less than; F, fine; C, coarse; VF, very fine; VC, very coarse; M, medium; TR, trace; - , not detected; grain sizes in millimeters]

\begin{tabular}{|c|c|c|c|c|c|c|c|c|c|c|c|}
\hline \multirow[b]{2}{*}{$\begin{array}{l}\text { Depth } \\
(\mathrm{cm})\end{array}$} & \multicolumn{3}{|c|}{ Total } & \multirow{2}{*}{ 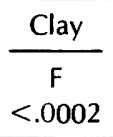 } & \multicolumn{2}{|c|}{ Silt } & \multicolumn{5}{|c|}{ Sand } \\
\hline & $\begin{array}{l}\text { Clay } \\
<.002\end{array}$ & $\begin{array}{c}\text { Silt } \\
.002-.05\end{array}$ & $\begin{array}{l}\text { Sand } \\
.05-2\end{array}$ & & $\begin{array}{c}F \\
.002-.02\end{array}$ & $\begin{array}{c}C \\
.02-.05\end{array}$ & $\begin{array}{c}\text { VF } \\
.05-.10\end{array}$ & $\begin{array}{c}F \\
.10-.25\end{array}$ & $\begin{array}{c}M \\
.25-.50\end{array}$ & $\begin{array}{c}\mathrm{C} \\
.5-1\end{array}$ & $\begin{array}{l}\text { VC } \\
1-2\end{array}$ \\
\hline $0-12 \ldots$ Ap & 6.8 & 26.9 & 66.3 & 0.9 & 18.7 & 8.2 & 2.8 & 25.9 & 32.9 & 4.5 & 0.2 \\
\hline $12-22 \ldots A 12$ & 8.2 & 31.9 & 59.9 & 2.5 & 22.5 & 9.4 & 2.4 & 23.2 & 29.4 & 4.5 & .4 \\
\hline $22-40-. \mathrm{B} 21 \mathrm{t}$ & 22.9 & 38.9 & 38.2 & 9.4 & 29.5 & 9.4 & 1.4 & 14.8 & 19.1 & 2.8 & .1 \\
\hline $40-63--B 22 t$ & 23.4 & 39.4 & 37.2 & 9.8 & 28.7 & 10.7 & 1.4 & 14.7 & 18.6 & 2.5 & TR \\
\hline $63-79 \ldots B 23 t$ & 13.4 & 23.6 & 63.0 & 4.9 & 17.0 & 6.6 & 2.2 & 24.9 & 31.9 & 3.9 & .1 \\
\hline $79-95--$ B31 & 6.4 & 10.7 & 82.9 & 1.2 & 7.2 & 3.5 & 2.7 & 34.1 & 40.4 & 5.3 & .4 \\
\hline $95-121-{\mathrm{B} 32 \mathrm{~A}^{\prime} 2}^{2}$ & 3.6 & 6.5 & 89.9 & .8 & 5.2 & 1.3 & 2.4 & 41.5 & 42.3 & 3.4 & .3 \\
\hline $121-130--B^{\prime} 21$ hir & 3.3 & 4.8 & 91.9 & 1.2 & 3.3 & 1.5 & 4.6 & 46.7 & 38.3 & 2.2 & .1 \\
\hline $130-150-B^{\prime} 22$ hir & 0.8 & 4.2 & 95.0 & .8 & 2.9 & 1.3 & 8.0 & 38.8 & 43.6 & 4.3 & .3 \\
\hline $150-159--B^{\prime} 23 h$ & .8 & 1.3 & 97.9 & -- & 0.8 & 0.5 & 4.3 & 34.0 & 49.4 & 8.3 & 1.9 \\
\hline $159-169-B^{\prime} 24 h$ & .4 & 2.4 & 97.2 & -- & 1.2 & 1.2 & 3.4 & 41.5 & 48.4 & 3.3 & .6 \\
\hline
\end{tabular}

Table $5 C$. Weight percent of oxides in soil horizons at site 4, Nelsonia [-- means not detected; TR means trace]

\begin{tabular}{|c|c|c|c|c|c|c|c|c|c|c|c|}
\hline Oxide & \multicolumn{11}{|c|}{ Horizon, depth $(\mathrm{cm})$} \\
\hline $\mathrm{Al}_{2} \mathrm{O}_{3} \ldots$ & 4.15 & 5.28 & 9.42 & 10.43 & 6.41 & 3.38 & 2.13 & 3.64 & 3.27 & 1.81 & 1.90 \\
\hline $\mathrm{Fe}_{2} \mathrm{O}_{3} \ldots \ldots$ & 1.11 & 1.58 & 3.70 & 4.21 & 2.42 & 1.05 & 0.33 & 0.89 & 0.33 & 0.002 & TR \\
\hline $\mathrm{TiO}_{2} \ldots \ldots$ & .57 & .67 & .81 & .87 & .66 & .52 & .31 & .40 & .35 & .24 & .13 \\
\hline $\mathrm{P}_{2} \mathrm{O}_{5} \ldots \ldots$ & .06 & .02 & .04 & .054 & .032 & .073 & .01 & .015 & TR & $\mathrm{TR}$ & TR \\
\hline $\mathrm{MnO} \ldots \ldots$ & .03 & .03 & .03 & .036 & .029 & .017 & -- & .014 & TR & TR & TR \\
\hline Total $\ldots$ & 93.7 & 97.5 & 96.2 & 95.6 & 96.1 & 100.7 & 103.6 & 97.0 & 98.1 & 100.5 & 100.9 \\
\hline $\mathrm{Fe}_{2} \mathrm{O}_{3}+\mathrm{Al}_{2} \mathrm{O}_{3} / \mathrm{SiO}_{2}--$ & 6.1 & 7.7 & 16.3 & 18.7 & 10.3 & 4.7 & 2.5 & 5.0 & 3.9 & 1.9 & 1.8 \\
\hline
\end{tabular}


Table 5D. Analyses of extractable Fe, Al, and $\mathrm{Mn}$, oxalates, ratio clay, and bulk density of soil horizons at site 4, Nelsonia [TR means trace; -- means not detected; * means estimated]

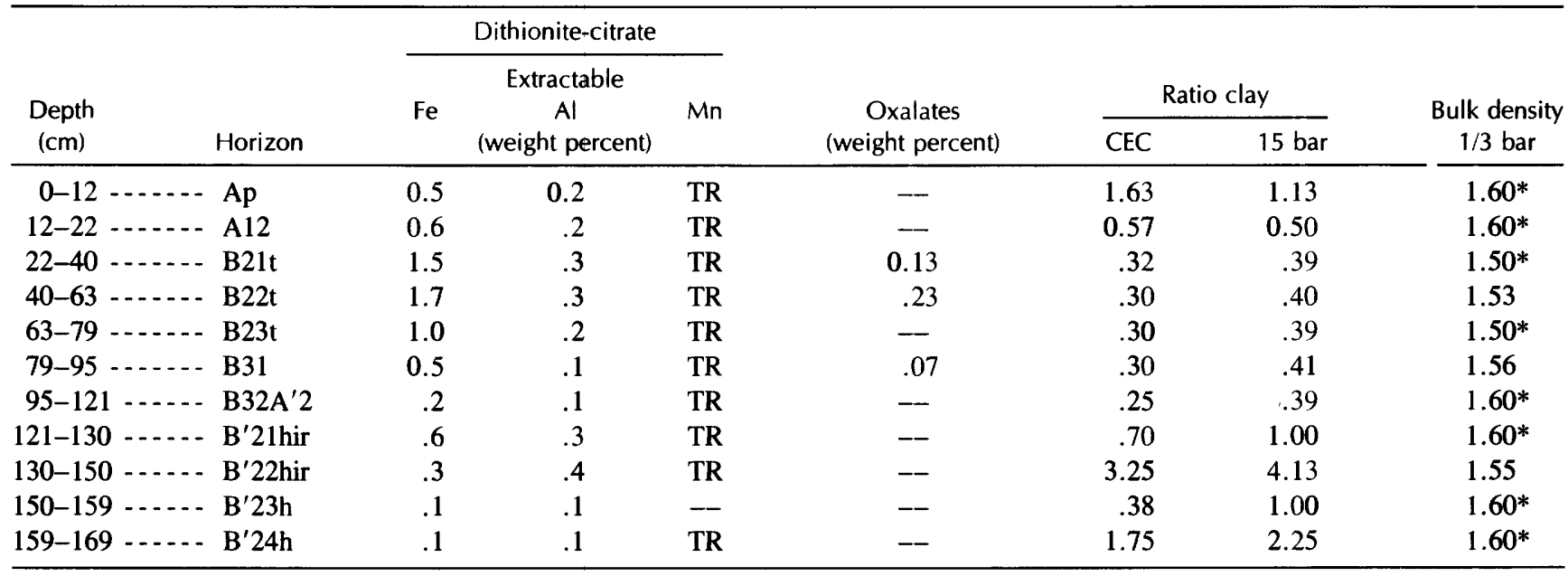

Table 5E. Analyses of extractable bases, extractable Al, cation exchange capacity (CEC), Al saturation, and pH for soil horizons at site 4, Nelsonia [-- means not detected; TR means trace]

\begin{tabular}{|c|c|c|c|c|c|c|c|c|c|c|c|c|c|}
\hline \multirow{3}{*}{$\begin{array}{l}\text { Depth } \\
(\mathrm{cm})\end{array}$} & \multirow[b]{3}{*}{ Horizon } & \multirow{2}{*}{\multicolumn{4}{|c|}{$\begin{array}{c}\mathrm{NH}_{4} \mathrm{OAC} \\
\text { extractable bases }\end{array}$}} & \multirow[b]{3}{*}{ Acidity } & \multirow{3}{*}{$\begin{array}{c}\text { Extractable } \\
\mathrm{Al}\end{array}$} & \multirow{2}{*}{\multicolumn{3}{|c|}{ CEC }} & \multirow{3}{*}{$\begin{array}{c}\text { Al } \\
\text { saturation }\end{array}$} & \multicolumn{2}{|c|}{$\mathrm{pH}$} \\
\hline & & & & & & & & & & & & \multirow{2}{*}{$\begin{array}{c}\mathrm{CaCl}_{2} \\
(.01 \mathrm{M}) \\
1: 2 \\
\end{array}$} & \multirow{2}{*}{$\begin{array}{l}\mathrm{H}_{2} \mathrm{O} \\
1: 1\end{array}$} \\
\hline & & $\mathrm{Ca}$ & $\mathrm{Mg}$ & $\mathrm{Na}$ & $\mathrm{K}$ & & & Sum cats & $\mathrm{NH}_{4} \mathrm{OAC}$ & bases $+\mathrm{Al}$ & & & \\
\hline \multicolumn{2}{|c|}{$0-12 \ldots$ Ap } & 5.6 & 1.5 & TR & 0.7 & 10.5 & 0.1 & 18.3 & 11.1 & 7.9 & 1 & 4.8 & 5.0 \\
\hline \multicolumn{2}{|c|}{$12-22 \ldots$ A12 } & 1.4 & 0.4 & -- & .2 & 6.0 & .7 & 8.0 & 4.7 & 2.7 & 26 & 4.6 & 5.2 \\
\hline \multicolumn{2}{|c|}{$22-40-.-B 21 t$} & 1.8 & .8 & TR & .4 & 8.1 & 1.7 & 11.1 & 7.4 & 4.7 & 36 & 4.4 & 5.1 \\
\hline \multicolumn{2}{|c|}{$40-63 \ldots-B 22 t$} & 1.2 & .6 & TR & .2 & 8.9 & 2.7 & 10.9 & 7.1 & 4.7 & 57 & 4.2 & 4.8 \\
\hline \multicolumn{2}{|c|}{$63-79 \ldots$ B23t } & 0.7 & .4 & -- & .1 & 5.8 & 1.4 & 7.0 & 4.0 & 2.6 & 54 & 4.2 & 4.9 \\
\hline \multicolumn{2}{|c|}{ 79-95 - - B B1 } & .3 & .3 & -- & TR & 2.9 & .6 & 3.5 & 1.9 & 1.2 & 50 & 4.3 & 4.9 \\
\hline \multicolumn{2}{|c|}{$95-121--\mathrm{B}^{2} 3 \mathrm{~A}^{\prime} 2$} & .3 & .2 & -- & .1 & 2.7 & .1 & 3.3 & 0.9 & 0.7 & 14 & 4.7 & 5.3 \\
\hline \multirow{2}{*}{\multicolumn{2}{|c|}{$\begin{array}{l}121-130-B^{\prime} 21 \mathrm{hir} \\
130-150--B^{\prime} 22 \mathrm{hir}\end{array}$}} & .1 & TR & -- & TR & 7.8 & .4 & 7.9 & 2.3 & .5 & 80 & 4.9 & 5.2 \\
\hline & - B'22hir & - & -- & - & TR & 9.8 & .2 & 8.8 & 2.6 & .2 & 100 & 5.2 & 5.3 \\
\hline \multicolumn{2}{|c|}{$150-159--B^{\prime} 23 h$} & -- & - & -- & -- & 3.2 & .1 & 3.2 & .3 & .1 & 100 & 5.1 & 5.4 \\
\hline \multicolumn{2}{|c|}{$159-169$ - - B'24h } & -- & $\ldots$ & -- & -- & 4.6 & .1 & 4.6 & .7 & .1 & 100 & 5.1 & 5.5 \\
\hline
\end{tabular}


Table 6A. Description of physical characteristics of soil horizons at site 5, Persimmon Point

[The Persimmon Point site (fig. 1) is about 16 km west-northwest of the Joynes Neck locality in Accomack County, Va. (37 $50^{\prime} \mathrm{N}$. lat, $75^{\circ} 32^{\prime} \mathrm{W}$. long , Bloxom 7 1/2 min. topographic quadrangle). It is $12 \mathrm{~m} \mathrm{MSL}$ and like the Nelsonia site the soil is developed in the 200,000 year Omar Formation. The unweathered parent material of cross-bedded quartz sand and pebble gravel also shows marine influence by the presence of borings, flasier structure, and ophiomora burrows. The best exposure of the parent material is in the sand pit about $0.8 \mathrm{~km}$ to the east of the study site. The water table was intercepted at $290 \mathrm{~cm}]$

\begin{tabular}{|c|c|c|c|c|c|c|c|}
\hline $\begin{array}{l}\text { Depth } \\
(\mathrm{cm})\end{array}$ & Horizon & Moist color ${ }^{1}$ & Texture $^{2}$ & Structure $^{3}$ & Clay skins & Roots $^{4}$ & Boundary 5 \\
\hline $0-24 \ldots \ldots$ & Ap & 10YR4/3 & fsl & $1 \mathrm{mgr}$ & & fvf & as \\
\hline $44-65 \ldots$ & $\mathrm{B} 22 \mathrm{t}$ & 7.5YR5/6 & scl & $1 \mathrm{msbk}$ & & fvf & cs \\
\hline $65-84 \cdots \cdots$ & $\mathrm{B} 23 \mathrm{t}$ & 7.5YR5/6 & $\mathrm{scl}$ & $1 \mathrm{msbk}$ & few, thin, patchy & fvf & aw \\
\hline 84-99 _ . . & $\mathrm{B} 24 \mathrm{t}$ & $7.5 \mathrm{YR} 5 / 6$ & fsl & $1 \mathrm{msbk}$ & few, thin, patchy & fvf & $\mathrm{cs}$ \\
\hline $150-173 \ldots$ & IIB32 & $7.5 \mathrm{YR} 5 / 8$ & s & SG & & & cs \\
\hline $173-200 \ldots$ & IIB33 & $7.5 \mathrm{YR} 5 / 6$ & s & SG & & & cs \\
\hline $200-232 \ldots$ & IIC & $2.5 \mathrm{YR} 7 / 6$ & s & SG & & & \\
\hline
\end{tabular}

${ }^{1}$ Color: Munsell notation

${ }^{2}$ Texture: $l=l o a m, s l=$ sandy loam, $f s l=$ fine sandy loam, $s c l=$ sandy clay loam, ls=loamy sand, $s=$ sand, $g=$ gravel

${ }^{3}$ Structure: 1 =weak, 2 =moderate, $m=$ medium, $g r=g r a n u l a r, ~ s b k=$ subangular blocky, $p=$ platy, $S G=$ single grain, $M A=m a s s i v e$

${ }^{4}$ Roots: $\mathrm{ff}=$ few fine, $\mathrm{mf}=$ many fine, $\mathrm{fvf}=\mathrm{few}$ very fine, $\mathrm{mvf}=$ many very fine

${ }^{5}$ Boundary: $c s=$ clear smooth, as = abrupt smooth, $\mathrm{cw}=$ clear wavy, $\mathrm{gs}=$ gradual smooth, aw =abrupt wavy

Table 6B. Textural analyses of soil horizons at site 5, Persimmon Point [Sampled as: fine-loamy, mixed, thermic Typic Hapludult; <, less than; F, fine; C, coarse; VF, very fine; VC, very coarse; M, medium; ,-- not detected; grain sizes in millimeters]

\begin{tabular}{|c|c|c|c|c|c|c|c|c|c|c|c|}
\hline \multirow[b]{2}{*}{$\begin{array}{l}\text { Depth } \\
\text { (cm) }\end{array}$} & \multicolumn{3}{|c|}{ Total } & \multirow{2}{*}{$\frac{\text { Clay }}{F}$} & \multicolumn{2}{|c|}{ Silt } & \multicolumn{5}{|c|}{ Sand } \\
\hline & $\begin{array}{l}\text { Clay } \\
<.002\end{array}$ & $\begin{array}{c}\text { Silt } \\
.002-.05\end{array}$ & $\begin{array}{l}\text { Sand } \\
.05-2\end{array}$ & & $\begin{array}{c}\mathbf{F} \\
.002-.02\end{array}$ & $\begin{array}{c}C \\
.02-.05\end{array}$ & $\begin{array}{c}\text { VF } \\
.05-.10\end{array}$ & $\begin{array}{c}\mathbf{F} \\
.10-.25\end{array}$ & $\begin{array}{c}M \\
.25-.50\end{array}$ & $\begin{array}{c}C \\
.5-1\end{array}$ & $\begin{array}{l}\text { VC } \\
1-2\end{array}$ \\
\hline $0-24 \ldots$ Ap & 8.2 & 35.8 & 56.0 & 2.9 & 26.2 & 9.6 & 1.5 & 7.8 & 33.2 & 12.3 & 1.2 \\
\hline $24-44--B 21 t$ & 21.7 & 31.7 & 46.6 & 14.3 & 22.1 & 9.6 & 1.3 & 5.6 & 31.4 & 7.3 & 1.0 \\
\hline $44-65---B 22 t$ & 22.1 & 30.8 & 47.1 & 10.6 & 22.5 & 8.3 & 1.3 & 6.3 & 32.4 & 6.3 & 0.8 \\
\hline $65-84--B 23 t$ & 17.1 & 22.4 & 60.5 & 9.8 & 16.3 & 6.1 & 1.4 & 6.8 & 41.1 & 9.9 & 1.3 \\
\hline $84-99--$ - B24t & 15.1 & 15.5 & 69.4 & 7.3 & 10.2 & 5.3 & 1.6 & 7.4 & 48.5 & 10.2 & 1.7 \\
\hline 99-122 - - IIB25ir & 2.4 & 2.1 & 95.5 & 1.2 & 1.2 & 0.9 & 1.1 & 15.0 & 73.7 & 5.3 & .4 \\
\hline $122-150--$ IIB31 & 1.6 & 0.6 & 97.8 & 0.8 & 0.4 & .2 & 0.2 & 3.4 & 56.4 & 35.0 & 2.8 \\
\hline 150-173 - - IIB32 & -- & 1.2 & 98.8 & -- & .4 & .8 & .3 & 3.9 & 54.9 & 36.8 & 2.9 \\
\hline $173-200$ - IIB33 & 0.4 & .7 & 98.9 & -- & .7 & -- & .6 & 2.8 & 31.7 & 43.8 & 20.0 \\
\hline 200-232 - - IIC & -- & .6 & 99.4 & -- & .4 & .2 & .3 & 9.0 & 65.3 & 24.3 & .5 \\
\hline
\end{tabular}

Table $6 C$. Weight percent of oxides in soil horizons at site 5, Persimmon Point

[TR means trace]

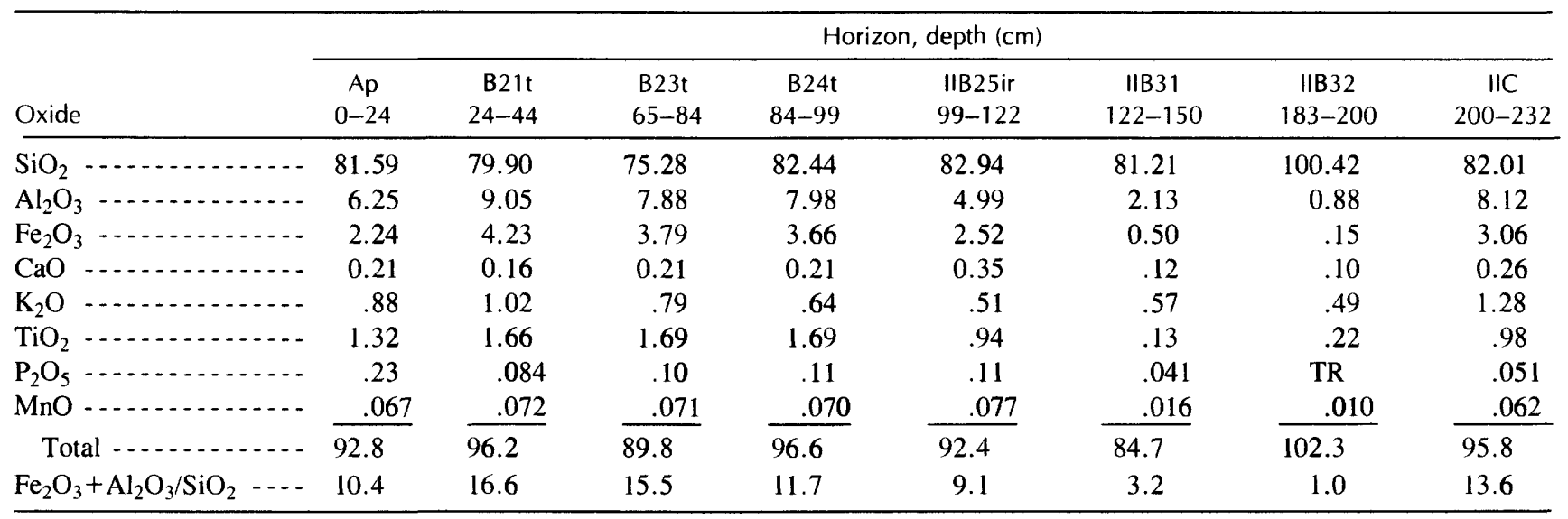


Table 6D. Analyses of extractable $\mathrm{Fe}, \mathrm{Al}$, and $\mathrm{Mn}$, oxalates, ratio clay, and bulk density of soil horizons at site 5, Persimmon Point [TR means trace; - means not detected; * means estimated]

\begin{tabular}{|c|c|c|c|c|c|c|c|}
\hline \multirow{3}{*}{$\begin{array}{l}\text { Depth } \\
\text { (cm) }\end{array}$} & \multicolumn{3}{|c|}{ Dithionite-citrate } & \multirow{3}{*}{$\begin{array}{c}\text { Oxalates } \\
\text { (weight percent) }\end{array}$} & & & \multirow{3}{*}{$\begin{array}{l}\text { Bulk density } \\
1 / 3 \mathrm{bar}\end{array}$} \\
\hline & \multirow{2}{*}{$\mathrm{Fe}$} & \multirow{2}{*}{$\begin{array}{c}\text { Extractable } \\
\mathrm{Al} \\
\text { (weight percent) }\end{array}$} & \multirow{2}{*}{ Mn } & & \multicolumn{2}{|c|}{ Ratio clay } & \\
\hline & & & & & CEC & 15 bar & \\
\hline $0-24 \ldots \ldots$ Ap & 0.7 & 0.2 & TR & 0.07 & 0.57 & 0.50 & 1.69 \\
\hline $24-44 \ldots \ldots-B 21 t$ & 1.5 & .3 & TR & .21 & .29 & .39 & 1.69 \\
\hline $44-65 \ldots \ldots . \quad B 22 t$ & 1.5 & .3 & TR & .17 & .26 & .37 & 1.51 \\
\hline $65-84 \ldots \ldots-13 t$ & 1.3 & .3 & TR & - & .27 & .40 & $1.50 *$ \\
\hline $84-99 \quad \ldots \ldots-B_{1}$ & 1.4 & .3 & TR & .34 & .27 & .43 & 1.51 \\
\hline $99-122-\ldots \ldots$ IIB25ir & .8 & .4 & TR & .50 & .50 & .83 & 1.87 \\
\hline $122-150 \ldots \ldots$ IIB31 & .4 & .2 & TR & -- & .63 & .69 & $1.80^{*}$ \\
\hline $150-173 \ldots \ldots$ IIB32 & .2 & .1 & TR & -- & - & -- & $1.80^{*}$ \\
\hline 173-200 -..... IIB33 & .2 & .1 & TR & -- & .50 & 1.25 & $1.80^{*}$ \\
\hline $200-232 \ldots \ldots$ IIC & .1 & .1 & -- & .01 & -- & - & $1.80 *$ \\
\hline
\end{tabular}

Table 6E. Analyses of extractable bases, extractable Al, cation exchange capacity (CEC), Al saturation, and pH for soil horizons at site 5, Persimmon Point

[-- means not detected; TR means trace]

\begin{tabular}{|c|c|c|c|c|c|c|c|c|c|c|c|c|c|}
\hline \multirow{3}{*}{$\begin{array}{l}\text { Depth } \\
(\mathrm{cm})\end{array}$} & \multirow[b]{3}{*}{ Horizon } & \multirow{2}{*}{\multicolumn{4}{|c|}{$\begin{array}{c}\mathrm{NH}_{4} \mathrm{OAC} \\
\text { extractable bases }\end{array}$}} & \multirow[b]{3}{*}{ Acidity } & \multirow{3}{*}{$\begin{array}{l}\text { Extractable } \\
\text { Al }\end{array}$} & \multirow{2}{*}{\multicolumn{3}{|c|}{ CEC }} & \multirow{3}{*}{$\begin{array}{c}\text { Al } \\
\text { saturation }\end{array}$} & \multicolumn{2}{|c|}{$\mathrm{pH}$} \\
\hline & & & & & & & & & & & & \multirow{2}{*}{$\begin{array}{c}\mathrm{CaCl}_{2} \\
(.01 \mathrm{M}) \\
1: 2\end{array}$} & \multirow{2}{*}{$\begin{array}{r}\mathrm{H}_{2} \mathrm{O} \\
1: 1\end{array}$} \\
\hline & & $\mathrm{Ca}$ & $\mathrm{Mg}$ & $\mathrm{Na}$ & $\mathrm{K}$ & & & Sum cats & $\mathrm{NH}_{4} \mathrm{OAC}$ & bases $+\mathrm{Al}$ & & & \\
\hline \multicolumn{2}{|c|}{$0-24 \ldots$ Ap } & 0.6 & 0.2 & -- & 0.3 & 7.7 & 1.3 & 8.8 & 4.7 & 2.4 & 54 & 4.2 & 4.5 \\
\hline \multicolumn{2}{|c|}{$24-44 \ldots$ B21t } & 0.8 & 0.4 & -- & .4 & 5.4 & 2.4 & 10.0 & 6.2 & 4.0 & 60 & 4.1 & 4.6 \\
\hline \multicolumn{2}{|c|}{$44-65--B 22 t$} & 1.1 & 0.5 & -- & .4 & 6.8 & 1.9 & 8.8 & 5.7 & 3.9 & 49 & 4.2 & 4.7 \\
\hline \multicolumn{2}{|c|}{$65-84--B 23 t$} & 1.6 & 0.5 & -- & .4 & 4.8 & 0.8 & 7.3 & 4.7 & 3.3 & 24 & 4.5 & 4.9 \\
\hline \multicolumn{2}{|c|}{$84-99---$ B24t } & 1.5 & 0.4 & -- & .4 & 5.3 & 1.0 & 7.6 & 4.0 & 3.3 & 30 & 4.5 & 5.0 \\
\hline \multirow{2}{*}{\multicolumn{2}{|c|}{$\begin{array}{r}99-122-\text { - IIB25ir } \\
122-150 \text { - - IIB31 }\end{array}$}} & .3 & TR & -- & TR & 6.7 & - & 7.0 & 1.2 & -- & -- & 5.2 & 5.6 \\
\hline & & .4 & TR & - & TR & 3.3 & - & 3.7 & 1.0 & -- & -- & 5.4 & 5.8 \\
\hline \multicolumn{2}{|c|}{ I50-173 - IIB32 } & .2 & TR & -- & -- & 2.3 & - & 2.5 & 0.2 & - & - & 5.4 & 5.8 \\
\hline \multicolumn{2}{|c|}{ 173-200 - - IIB33 } & .2 & TR & -- & - & 2.2 & -- & 2.4 & .2 & -- & - & 5.3 & 5.8 \\
\hline \multicolumn{2}{|c|}{ 200-232 _ - IIC } & .1 & - & -- & -- & 0.8 & -- & 0.9 & -- & -- & - & 5.4 & 5.8 \\
\hline
\end{tabular}

Table 7A. Description of physical characteristics of soil horizons at site 6, Norris Bridge

[The Norris Bridge study site (fig. 1) is located near the mouth of the Rappahannock River immediately to the east of Route 3 on the north side of the river in Lancaster County, Va. ( $37^{\circ} 38^{\prime} \mathrm{N}$. lat , $76^{\circ} 24^{\prime} \mathrm{W}$. long, $12 \mathrm{~m}$ MSL elevation, Irvington $71 / 2 \mathrm{~min}$. topographic quadrangle). The soil at the Norris Bridge locality is developed in massive quartz sand that constitutes the upper $4 \mathrm{~m}$ of sediment in a 12-m-thick transgressive marine unit of fossiliferous clay and cross-bedded and massive quartz sand. The age and location of this undesignated unit suggest that the surface has been influenced by aeolian processes. This is corroborated by the fact that the Omar Formation, the unit to which the Norris Bridge sediments are correlated, is dotted by Carolina Bays]

\begin{tabular}{|c|c|c|c|c|c|c|c|}
\hline $\begin{array}{l}\text { Depth } \\
\text { (cm) }\end{array}$ & Horizon & Moist color ${ }^{1}$ & Texture $^{2}$ & Structure $^{3}$ & Clay skins & Roots $^{4}$ & Boundary $^{5}$ \\
\hline $0-25 \cdots$ & Ap & $10 \mathrm{YR} 4 / 3$ & ls & $1 \mathrm{fgr}$ & & $\mathrm{ffm}$ & as \\
\hline $25-34 \ldots$ & A2 & 10YR4/6 & sl & $1 \mathrm{msbk}$ & & ff & cs \\
\hline $34-48 \ldots$ & $\mathrm{B} 21 \mathrm{t}$ & $7.5 Y R 5 / 6$ & sl & lmsbk & & ff & $\mathrm{cs}$ \\
\hline $48-70-\ldots$ & $\mathrm{B} 22 \mathrm{t}$ & 5YR5/6 & scl & $1 \mathrm{~m}$ and csbk & few, thin, patchy & ff & gs \\
\hline $70-96 \ldots$ & $\mathrm{B} 23 \mathrm{t}$ & $5 Y R 5 / 6$ & ls & lcsbk & few bridges & ff & cs \\
\hline $96-138 \ldots$ & B31 & $7.5 Y R 5 / 6$ & $\mathrm{~s}$ & SG & & & gs \\
\hline $138-170 \ldots$ & B32 & $7.5 Y R 5 / 6$ & $\mathrm{~s}$ & SG & & & gs \\
\hline $170-200-\ldots$ & $\mathrm{Cl}$ & 10YR5/8 & $\mathrm{s}$ & SG & & & gs \\
\hline $200-230 \ldots$ & IIC2 & 10YR5/8 & $\mathrm{s}$ & SG & & & \\
\hline
\end{tabular}

${ }^{1}$ Color: Munsell notation

${ }^{2}$ Texture: $\mathrm{I}=\mathrm{loam}, \mathrm{sl}=$ sandy loam, $\mathrm{s}=$ loamy sand, $\mathrm{scl}=$ sand clay loam, $\mathrm{s}=$ sand, $\mathrm{g}=$ gravel

${ }^{3}$ Structure: $1=$ weak, $2=$ moderate, $\mathrm{m}=$ medium, $\mathrm{f}=$ fine, $\mathrm{c}=$ coarse, $\mathrm{gr}=$ granular, sbk=subangular blocky, $\mathrm{p}=$ platy, $\mathrm{SG}=$ single grain

${ }^{4}$ Roots: $\mathrm{ff}=$ few fine, $\mathrm{mf}=$ many fine, $\mathrm{ffm}=$ few fine and medium

${ }^{5}$ Boundary: $\mathrm{cs}=$ clear smooth, as $=$ abrupt smooth, $\mathrm{cw}=$ clear wavy, $\mathrm{gs}=$ gradual smooth 
Table 7B. Textural analyses of soil horizons at site 6 , Norris Bridge

[Sampled as: fine-loamy, mixed, thermic Typic Hapludult; <, less than; F, fine; C, coarse; VF, very fine; VC, very coarse; M, medium; TR, trace; --, not detected; grain sizes in millimeters]

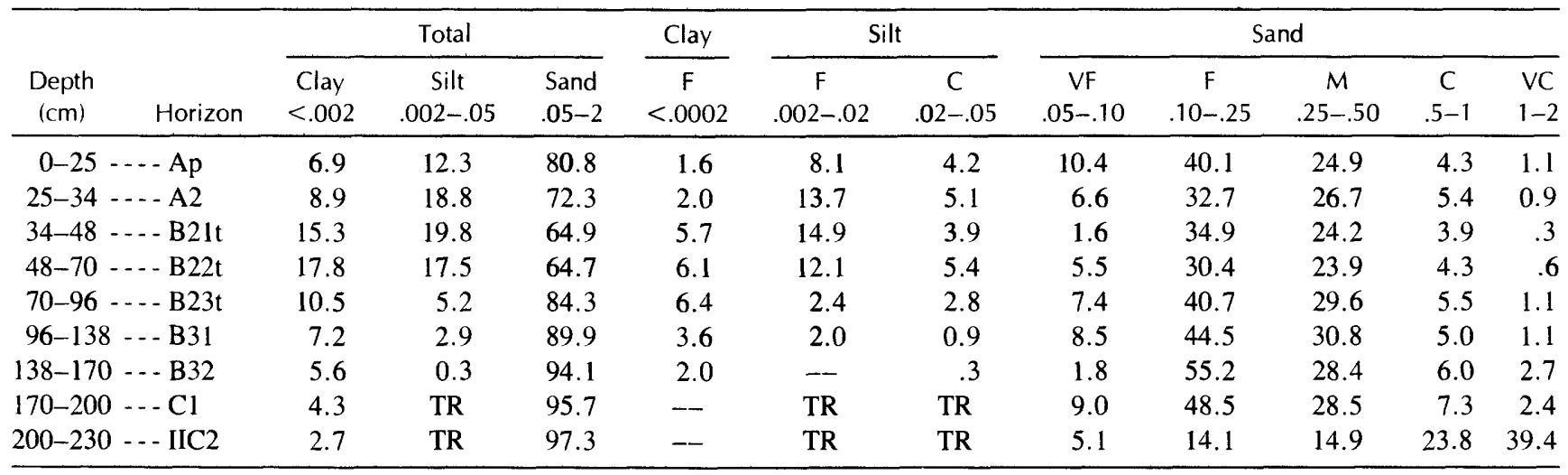

Table 7 C. Weight percent of oxides in soil horizons at site 6 , Norris Bridge

\begin{tabular}{|c|c|c|c|c|c|c|c|c|c|}
\hline \multirow[b]{2}{*}{ Oxide } & \multicolumn{9}{|c|}{ Horizon, depth $(\mathrm{cm})$} \\
\hline & $\begin{array}{c}A p \\
0-25\end{array}$ & $\begin{array}{c}\text { A2 } \\
25-34\end{array}$ & $\begin{array}{r}\text { B21t } \\
34-48\end{array}$ & $\begin{array}{c}\text { B22t } \\
48-70\end{array}$ & $\begin{array}{r}\text { B23t } \\
70-96\end{array}$ & $\begin{array}{c}\text { B31 } \\
96-138\end{array}$ & $\begin{array}{c}\text { B32 } \\
138-170\end{array}$ & $\begin{array}{c}C 1 \\
170-200\end{array}$ & $\begin{array}{c}11 \mathrm{C} 2 \\
200-230 \\
\end{array}$ \\
\hline $\mathrm{SiO}_{2}$ & 93.01 & 91.52 & 87.34 & 87.61 & 92.02 & 95.01 & 93.98 & 100.00 & 97.53 \\
\hline $\mathrm{Al}_{2} \mathrm{O}_{3} \ldots \ldots$ & 2.60 & 3.71 & 5.71 & 5.51 & 3.42 & 2.43 & 1.95 & 0.86 & 1.98 \\
\hline $\mathrm{Fe}_{2} \mathrm{O}_{3} \ldots \ldots$ & 1.52 & 2.23 & 2.51 & 3.49 & 2.52 & 2.10 & 2.93 & 1.01 & 1.02 \\
\hline $\mathrm{CaO}$ & 0.13 & 0.12 & 0.10 & 0.13 & 0.14 & 0.15 & 0.10 & .09 & 0.08 \\
\hline $\mathrm{K}_{2} \mathrm{O}$ & .24 & .24 & .23 & .26 & .49 & .43 & .24 & .19 & .19 \\
\hline $\mathrm{TiO}_{2} \ldots \ldots$ & .78 & .77 & .76 & .55 & .51 & .57 & .55 & .66 & .50 \\
\hline $\mathrm{P}_{2} \mathrm{O}_{5} \ldots$ & .057 & .048 & .065 & .06 & .127 & .083 & .042 & .029 & .024 \\
\hline $\mathrm{MnO}$ & .15 & .14 & .14 & .16 & .33 & .29 & .17 & .14 & .13 \\
\hline Total $\ldots$ & 98.5 & 98.8 & 96.9 & 97.8 & 99.6 & 101.06 & 100.0 & 103.0 & 101.5 \\
\hline $\mathrm{Fe}_{2} \mathrm{O}_{3}+\mathrm{Al}_{2} \mathrm{O}_{3} / \mathrm{SiO}_{2} \ldots \ldots$ & 4.4 & 6.5 & 9.4 & 10.3 & 6.5 & 4.8 & 5.2 & 1.9 & 3.1 \\
\hline
\end{tabular}

Table 7D. Analyses of extractable $\mathrm{Fe}, \mathrm{Al}$, and $\mathrm{Mn}$, oxalates, ratio clay, and bulk density of soil horizons at site 6, Norris Bridge [TR means trace; * means estimated; -- means not detected]

\begin{tabular}{|c|c|c|c|c|c|c|c|c|}
\hline \multirow{3}{*}{$\begin{array}{l}\text { Depth } \\
(\mathrm{cm})\end{array}$} & \multirow[b]{3}{*}{ Horizon } & \multicolumn{3}{|c|}{ Dithionite-citrate } & \multirow{3}{*}{$\begin{array}{c}\text { Oxalates } \\
\text { (weight percent) }\end{array}$} & & & \multirow{3}{*}{$\begin{array}{l}\text { Bulk density } \\
1 / 3 \text { bar }\end{array}$} \\
\hline & & \multirow{2}{*}{$\mathrm{Fe}$} & \multirow{2}{*}{$\begin{array}{c}\text { Extractable } \\
\text { Al } \\
\text { (weight percent) }\end{array}$} & \multirow{2}{*}{$\mathrm{Mn}$} & & \multicolumn{2}{|c|}{ Ratio clay } & \\
\hline & & & & & & CEC & 15 bar & \\
\hline $0-25$ & Ap & 0.4 & 0.1 & TR & -- & 0.36 & 0.33 & 1.71 \\
\hline $25-34$ & A2 & .6 & .1 & TR & 0.03 & .27 & .31 & 1.82 \\
\hline $34-48$ & --- B21t & 1.0 & .2 & TR & .06 & .26 & .32 & 1.71 \\
\hline $48-70$ & -...... B22t & 1.3 & .2 & TR & .09 & .29 & .35 & 1.63 \\
\hline $70-96$ & - B23t & .8 & .1 & -- & .08 & .25 & .33 & 1.63 \\
\hline $96-138$ & -... B31 & .6 & .1 & -- & -- & .25 & .32 & 1.58 \\
\hline $138-170$ & -... B32 & .5 & .1 & -- & -- & .23 & .32 & $1.70^{*}$ \\
\hline $170-200$ & $\ldots-\mathrm{Cl}$ & .4 & .1 & -- & -- & .26 & .30 & $1.70^{*}$ \\
\hline $200-230$ & -... IIC2 & .4 & .1 & -- & - & .33 & 3.26 & $1.70^{*}$ \\
\hline
\end{tabular}


Table $7 \boldsymbol{E}$. Analyses of extractable bases, extractable Al, cation exchange capacity (CEC), Al saturation, and pH for soil horizons at site 6 , Norris Bridge

[TR means trace; -- means not detected]

\begin{tabular}{|c|c|c|c|c|c|c|c|c|c|c|c|c|}
\hline \multirow{2}{*}{ Horizon } & \multirow{2}{*}{\multicolumn{4}{|c|}{$\begin{array}{c}\mathrm{NH}_{4} \mathrm{OAC} \\
\text { extractable bases }\end{array}$}} & \multirow{2}{*}{ Acidity } & \multirow{2}{*}{$\begin{array}{c}\text { Extractable } \\
\mathrm{Al}\end{array}$} & \multirow{2}{*}{\multicolumn{3}{|c|}{ CEC }} & \multirow{2}{*}{$\begin{array}{c}\mathrm{Al} \\
\text { saturation }\end{array}$} & \multicolumn{2}{|c|}{$\mathrm{pH}$} \\
\hline & & & & & & & & & & & $\begin{array}{c}\mathrm{CaCl}_{2} \\
(.01 \mathrm{M}) \\
1: 2\end{array}$ & $\begin{array}{l}\mathrm{H}_{2} \mathrm{O} \\
1: 1\end{array}$ \\
\hline $0-25 \ldots$ Ap & 1.0 & 0.2 & -- & 0.4 & 2.9 & 0.2 & 4.5 & 2.5 & 1.8 & 11 & 4.6 & 5.1 \\
\hline $25-34 \ldots A 2$ & 0.5 & .2 & -- & .2 & 3.1 & .6 & 4.0 & 2.4 & 1.5 & 40 & 4.3 & 4.9 \\
\hline $34-48 \ldots$ B21t & .8 & .4 & TR & .2 & 4.4 & .7 & 5.8 & 3.9 & 2.1 & 33 & 4.3 & 4.9 \\
\hline $70-96---B 23 t$ & 1.1 & .4 & -- & -- & 2.8 & .2 & 4.3 & 2.6 & 1.7 & 12 & 4.6 & 5.1 \\
\hline $96-138--B 31$ & 1.0 & .3 & - & -- & 1.9 & .2 & 3.2 & 1.8 & 1.4 & 7 & 4.8 & 5.3 \\
\hline $138-170--B 32$ & .8 & .2 & TR & - & 1.6 & $\mathrm{TR}$ & 2.6 & 1.3 & -- & -- & 5.0 & 5.5 \\
\hline $170-200--\mathrm{Cl}$ & .8 & .2 & TR & -- & 1.2 & -- & 2.2 & 1.1 & - & -- & 5.4 & 5.9 \\
\hline $200-230--$ IIC2 & .7 & .1 & TR & -- & 1.1 & -- & 1.9 & 0.9 & -- & -- & 5.3 & 5.9 \\
\hline
\end{tabular}

Table 8A. Description of physical characteristics of soil horizons at site 7, $23 \mathrm{~m}$ terrace

[The $23 \mathrm{~m}$ terrace locality is on the north side of the Rappahannock River, several hundred meters east of the junction of Routes 601 and 3 , Stafford County, Va. $\left(38^{\circ} 16^{\prime} \mathrm{N}\right.$. lat, $77^{\circ} 24^{\prime} \mathrm{W}$. long, $21 \mathrm{~m} \mathrm{MSL}$ elevation. Fredericksburg $71 / 2 \mathrm{~min}$. topographic quadrangle) (fig. 1). Although parent material was not reached, mineralogic evidence from the horizons sampled and the mineralogy and sedimentary structures from nearby outcrops indicate a fluvial origin. The alluvium is predominantly a quartz sand containing minor amounts of feldspar and rock fragments ]

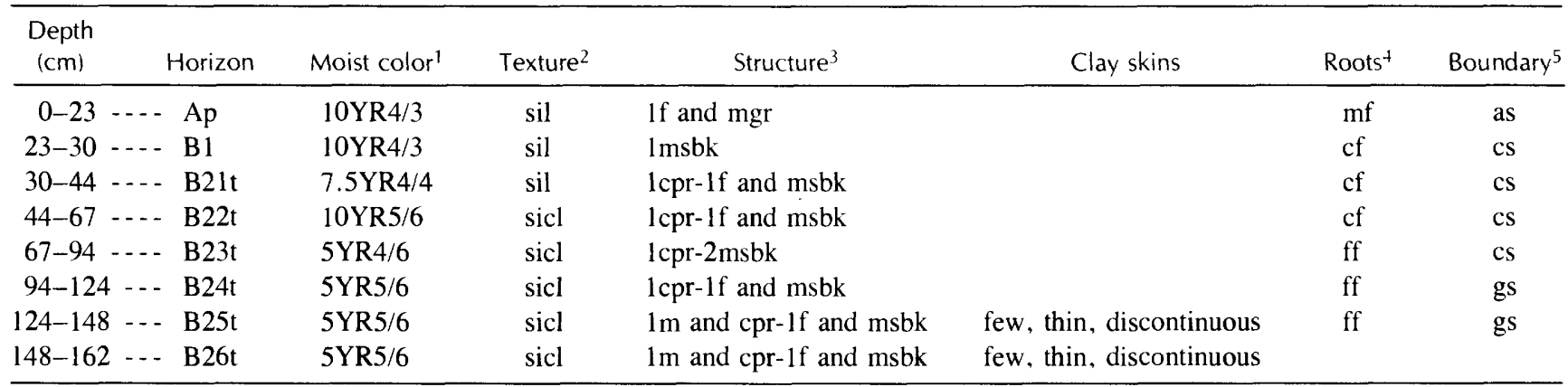

${ }^{1}$ Color: Munsell notation

2Texture: $l=$ loam, $\mathrm{s}=$ =sandy loam, sil=silty loam, sicl=silty clay loam, ls=loamy sand, $s=$ sand, $g=$ gravel

${ }^{3}$ Structure: $\mathrm{l}=$ weak, $2=$ moderate, $\mathrm{f}=$ fine, $\mathrm{c}=$ coarse, $\mathrm{g}=$ granular, sbk= subangular blocky, $\mathrm{p}=$ platy, $\mathrm{pr}=$ prismatic, $\mathrm{SG}=$ single grain

${ }^{4}$ Roots: $\mathrm{ff}=$ few fine, $\mathrm{mf}=$ many fine, $\mathrm{cf}=$ common fine

${ }^{5}$ Boundary: $\mathrm{cs}=$ clear smooth, as $=$ abrupt smooth, $\mathrm{cw}=$ clear wavy, $\mathrm{gs}=$ gradual $\mathrm{smooth}$

Table 8B. Textural analyses of soil horizons at site 7, $23 \mathrm{~m}$ terrace

[Sampled as: fine-loamy, mixed, thermic Typic Hapludult; <, less than; F, fine; C, course; VF, very fine; VC, very coarse; M, medium; TR, trace; grain sizes in millimeters]

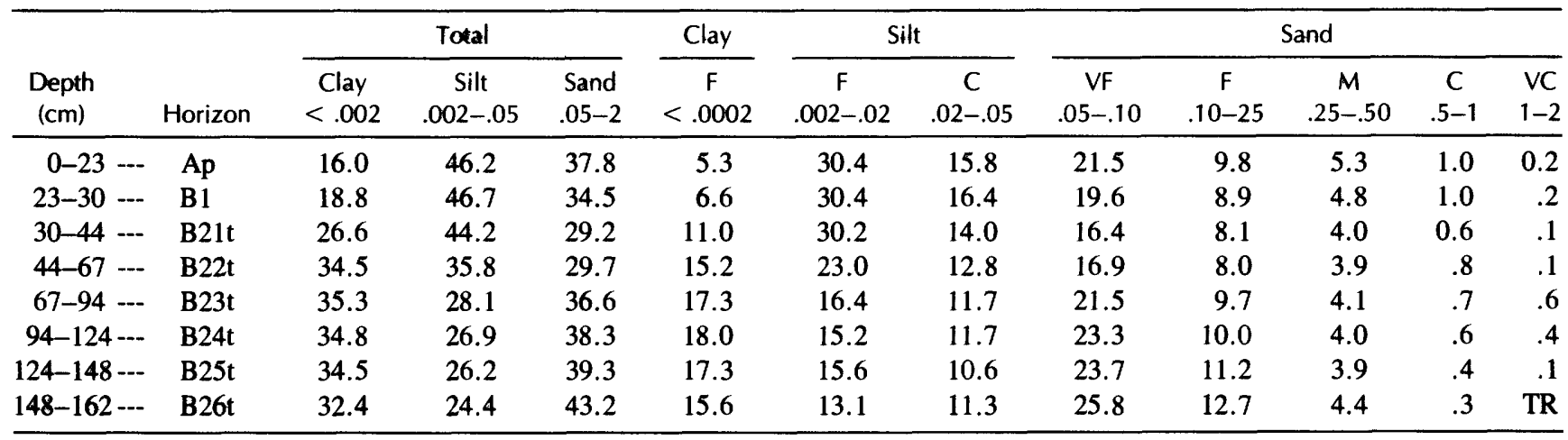


Table $\mathbf{8 C}$. Weight percent of oxides in soil horizons at site 7,23 m Rappahannock terrace

\begin{tabular}{|c|c|c|c|c|c|c|c|c|}
\hline \multirow[b]{2}{*}{ Oxide } & \multicolumn{8}{|c|}{ Horizon, depth $(\mathrm{cm})$} \\
\hline & $\begin{array}{c}\text { Ap } \\
0-23\end{array}$ & $\begin{array}{c}\mathrm{B} 1 \\
23-30\end{array}$ & $\begin{array}{c}B 21 t \\
30-44\end{array}$ & $\begin{array}{c}B 22 t \\
44-67\end{array}$ & $\begin{array}{c}B 23 t \\
67-94\end{array}$ & $\begin{array}{c}\text { B24t } \\
94-124\end{array}$ & $\begin{array}{c}\text { B25t } \\
124-148\end{array}$ & $\begin{array}{c}\text { B26t } \\
148-162\end{array}$ \\
\hline $\mathrm{SiO}_{2} \ldots$ & 75.06 & 79.09 & 75.82 & 70.78 & 69.60 & 67.98 & 67.37 & 68.18 \\
\hline $\mathrm{Al}_{2} \mathrm{O}_{3}$ & 8.82 & 10.04 & 11.89 & 14.17 & 14.66 & 15.59 & 16.93 & 16.41 \\
\hline $\mathrm{Fe}_{2} \mathrm{O}_{3} \ldots \ldots$ & 3.55 & 3.99 & 4.90 & 6.04 & 6.31 & 7.15 & 8.22 & 8.05 \\
\hline $\mathrm{CaO}$ & 0.49 & 0.49 & 0.42 & 0.45 & 0.43 & 0.31 & 0.27 & 0.28 \\
\hline $\mathrm{K}_{2} \mathrm{O} \ldots \ldots$ & 2.20 & 2.28 & 2.29 & 2.28 & 2.33 & 2.36 & 2.52 & 2.67 \\
\hline $\mathrm{TiO}_{2} \ldots$ & 1.78 & 1.84 & 1.80 & 1.76 & 1.83 & 1.88 & 1.89 & 1.93 \\
\hline $\mathrm{P}_{2} \mathrm{O}_{5} \ldots$ & .30 & .28 & .25 & .23 & .23 & .24 & .26 & .25 \\
\hline $\mathrm{MnO} \ldots$ & .22 & .25 & .17 & .12 & .16 & .095 & .084 & .083 \\
\hline Total $\ldots \ldots$ & 92.4 & 98.3 & 97.5 & 95.8 & 95.6 & 95.6 & 97.5 & 97.9 \\
\hline $\mathrm{Fe}_{2} \mathrm{O}_{3}+\mathrm{Al}_{2} \mathrm{O}_{3} / \mathrm{SiO}_{2} \ldots$ & 16.5 & 17.7 & 22.2 & 28.6 & 30.1 & 33.5 & 37.3 & 35.9 \\
\hline
\end{tabular}

Table 8D. Analyses of extractable Fe, Al, and Mn, oxalates, ratio clay, and bulk density of soil horizons at site $7,23 \mathrm{~m}$ terrace [TR means trace; - - means not detected]

\begin{tabular}{|c|c|c|c|c|c|c|c|}
\hline \multirow{3}{*}{$\begin{array}{l}\text { Depth } \\
(\mathrm{cm})\end{array} \quad$ Horizo } & \multicolumn{3}{|c|}{ Dithionite-citrate } & \multirow{3}{*}{$\begin{array}{c}\text { Oxalates } \\
\text { (weight percent) }\end{array}$} & & & \multirow{3}{*}{$\begin{array}{l}\text { Bulk density } \\
1 / 3 \text { bar }\end{array}$} \\
\hline & \multirow{2}{*}{$\mathrm{Fe}$} & \multirow{2}{*}{$\begin{array}{c}\text { Extractable } \\
\mathrm{Al} \\
\text { (weight percent) }\end{array}$} & \multirow{2}{*}{$\mathrm{Mn}$} & & \multicolumn{2}{|c|}{ Ratio clay } & \\
\hline & & & & & CEC & 15 bar & \\
\hline $0-23-\ldots$ Ap & 1.4 & 0.2 & 0.1 & -- & 0.48 & 0.46 & 1.44 \\
\hline $23-30 \ldots \ldots$ B1 & 1.6 & .3 & .1 & -- & .41 & .46 & 1.61 \\
\hline $30-44-\cdots B 21 t$ & 2.0 & .3 & .1 & -- & .25 & .40 & 1.57 \\
\hline $44-67 \ldots$ & 2.6 & .4 & .1 & -- & .27 & .41 & 1.50 \\
\hline $67-94-\ldots-B 23 t$ & 2.7 & .4 & .1 & 0.32 & .23 & .41 & 1.54 \\
\hline $84-124 \ldots \ldots-B 24 t$ & 3.1 & .4 & $\mathrm{TR}$ & .30 & .22 & .43 & 1.58 \\
\hline $124-148 \ldots \ldots$ B25t & 3.5 & .4 & TR & -- & .23 & .46 & 1.47 \\
\hline $148-162 \ldots$ B26t & 3.5 & .4 & TR & .31 & .23 & .46 & 1.46 \\
\hline
\end{tabular}

Table 8E. Analyses of extractable bases, extractable $\mathrm{Al}$, cation exchange capacity (CEC), and pH for soil horizons at site $7,23 \mathrm{~m}$ terrace

[TR means trace: -- means not detected]

\begin{tabular}{|c|c|c|c|c|c|c|c|c|c|c|c|}
\hline \multirow{2}{*}{$\begin{array}{l}\text { Depth } \\
(\mathrm{cm})\end{array}$} & \multirow{2}{*}{\multicolumn{4}{|c|}{$\begin{array}{c}\mathrm{NH}_{4} \mathrm{OAC} \\
\text { extractable bases }\end{array}$}} & \multirow{2}{*}{ Acidity } & \multirow{2}{*}{$\begin{array}{c}\text { Extractable } \\
\qquad \mathrm{Al}\end{array}$} & \multirow{2}{*}{\multicolumn{3}{|c|}{ CEC }} & \multicolumn{2}{|c|}{$\mathrm{pH}$} \\
\hline & & & & & & & & & & $\begin{array}{c}\mathrm{CaCl}_{2} \\
(.01 \mathrm{M}) \\
1: 2\end{array}$ & $\begin{array}{c}\mathrm{H}_{2} \mathrm{O} \\
1: 1\end{array}$ \\
\hline $0-23 \ldots$ Ap & 6.5 & 1.3 & -- & 0.6 & 4.3 & -- & 12.7 & 7.7 & -- & 6.1 & 6.4 \\
\hline $23-30 \ldots-$ Bl & 5.7 & 1.2 & -- & 6 & 4.5 & -- & 12.0 & 7.7 & -- & 6.4 & 6.8 \\
\hline $30-44 \ldots$ B2It & 4.7 & 1.2 & -- & .5 & 4.1 & -- & 10.5 & 6.7 & -- & 6.6 & 7.0 \\
\hline $67-94----$ B23t & 5.7 & 1.4 & -- & .4 & 4.9 & -- & 12.4 & 8.2 & -- & 6.6 & 6.9 \\
\hline $94-124 \ldots$ B24t & 3.9 & 1.6 & TR & .5 & 5.6 & -- & 11.6 & 7.5 & -- & 6.2 & 6.4 \\
\hline 124-148---- B25t & 2.9 & 2.0 & - & .7 & 7.4 & 0.2 & 13.0 & 7.8 & 5.8 & 5.2 & 5.5 \\
\hline $148-162-\cdots-B 26 t$ & 2.1 & 1.8 & -- & .7 & 7.9 & .4 & 12.5 & 7.5 & 5.0 & 4.9 & 5.2 \\
\hline
\end{tabular}


Table 9A. Description of physical characteristics of soil horizons at site $8,45 \mathrm{~m}$ terrace

[The $45 \mathrm{~m}$ terrace soil locality (fig. 1) is on the north side of the river, $0.4 \mathrm{~km}$ west of Welcome, Va., in King George County $\left(38^{\circ} 11^{\prime} \mathrm{N}\right.$. lat. $77^{\circ} 9^{\prime}$ W. long, $45 \mathrm{~m}$ MSL elevation. Port Royal $71 / 2 \mathrm{~min}$. topographic quadrangle). Like the $23 \mathrm{~m}$ terrace, the sediments are fluvial in origin and consist of quartz sands containing minor amounts of feldspar and rock fragments ]

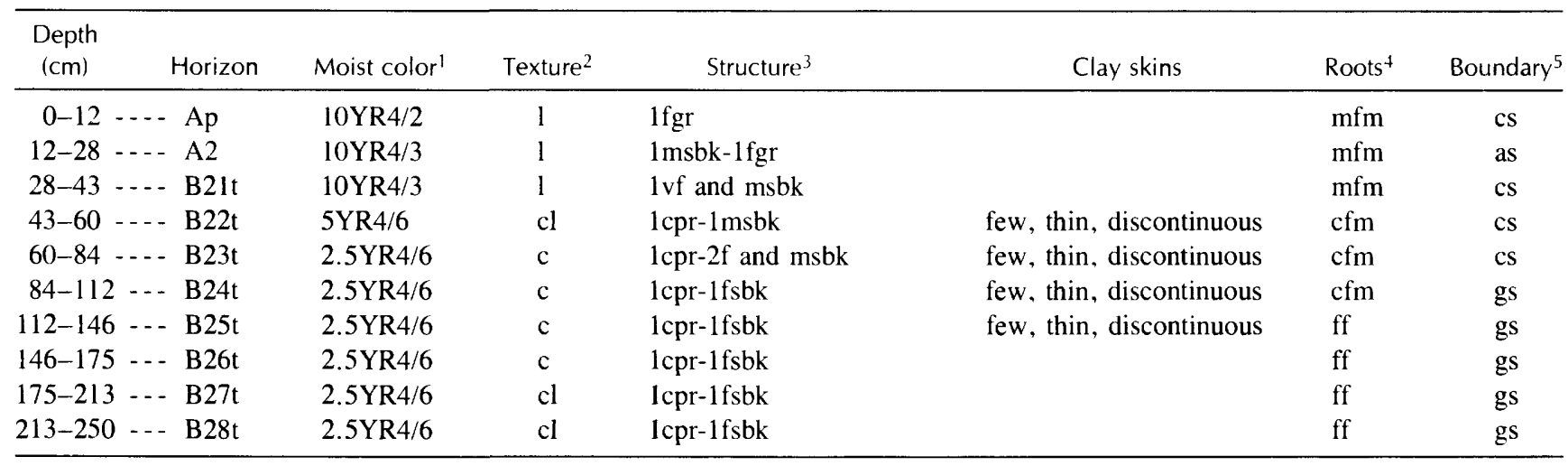

'Color: Munsell notation

${ }^{2}$ Texture: $\mathrm{l}=$ loam, $\mathrm{sl}=$ sandy loam, $\mathrm{ls}=$ loamy sand, $\mathrm{cl}=$ clay loam, $\mathrm{c}=$ clay, $\mathrm{s}=$ sand, $\mathrm{g}=$ gravel

${ }^{3}$ Structure: $1=$ weak, $2=$ moderate, $\mathrm{f}=$ fine, $\mathrm{vf}=$ very fine, $\mathrm{c}=$ coarse, $\mathrm{m}=$ medium, $\mathrm{gr}=$ granular, sbk=subangular blocky, $\mathrm{pl}=\mathrm{platy}, \mathrm{pr}=\mathrm{prismatic}$, $\mathrm{SG}=$ single grain

${ }^{4}$ Roots: $\mathrm{ff}=$ few fine, $\mathrm{mf}=$ many fine, $\mathrm{mfm}=$ many fine and medium, $\mathrm{cfm}=$ common fine and medium

${ }^{5}$ Boundary: $\mathrm{cs}=$ clear smooth, as $=$ abrupt smooth, $\mathrm{cw}=$ clear wavy, $\mathrm{gs}=$ gradual $\mathrm{smooth}$

Table 9B. Textural analyses of soil horizons at site $8,45 \mathrm{~m}$ terrace

[Sampled as: fine-loamy, over clayey, mixed, thermic Typic Paleudult; $<$, less than; F, fine; C, coarse; VF, very fine; VC, very coarse; M, medium; grain sizes in millimeters]

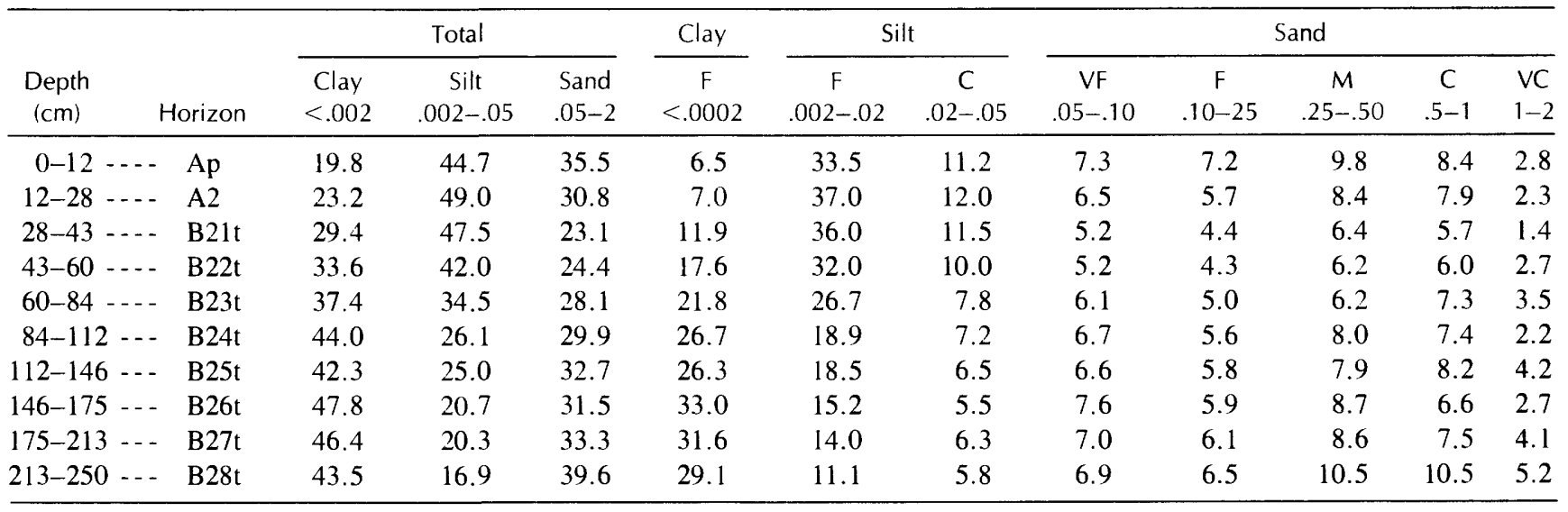

Table 9C. Weight percent of oxides in soil horizons at site $8,45 \mathrm{~m}$ terrace [Sampled as: fine-loamy, mixed, thermic Typic Paleudult]

\begin{tabular}{|c|c|c|c|c|c|c|c|c|c|c|}
\hline \multirow[b]{2}{*}{ Oxide } & \multicolumn{10}{|c|}{ Horizon, depth $(\mathrm{cm})$} \\
\hline & $\begin{array}{c}\text { Ap } \\
0-12\end{array}$ & $\begin{array}{c}B 1 \\
12-28\end{array}$ & $\begin{array}{c}\text { B21t } \\
28-43\end{array}$ & $\begin{array}{c}B 22 t \\
43-60\end{array}$ & $\begin{array}{r}\text { B23t } \\
60-94\end{array}$ & $\begin{array}{c}\text { B24t } \\
84-112\end{array}$ & $\begin{array}{c}\text { B25t } \\
112-146\end{array}$ & $\begin{array}{c}\text { B26t } \\
146-175\end{array}$ & $\begin{array}{c}B 27 t \\
175-213\end{array}$ & $\begin{array}{c}\text { B28t } \\
213-250\end{array}$ \\
\hline $\mathrm{SiO}_{2} \ldots$ & 77.27 & 82.57 & 75.32 & 76.38 & 74.51 & 72.40 & 71.09 & 70.94 & 65.78 & 73.68 \\
\hline $\mathrm{Al}_{2} \mathrm{O}_{3}$ & 7.42 & 8.12 & 11.00 & 11.79 & 12.62 & 14.42 & 13.46 & 14.37 & 14.51 & 13.81 \\
\hline $\mathrm{Fe}_{2} \mathrm{O}_{3} \ldots \ldots$ & 3.33 & 3.42 & 4.94 & 5.32 & 5.60 & 6.12 & 6.05 & 6.38 & 6.22 & 6.29 \\
\hline $\mathrm{CaO}$ & 0.74 & 0.30 & 0.26 & 0.25 & 0.26 & 0.26 & 0.24 & 0.25 & 0.22 & 0.19 \\
\hline $\mathrm{K}_{2} \mathrm{O}$ & 1.15 & 1.25 & 1.43 & 1.36 & 1.13 & .84 & .80 & .72 & .64 & .62 \\
\hline $\mathrm{TiO}_{2} \ldots$ & 1.33 & 1.39 & 1.41 & 1.36 & 1.36 & 1.42 & 1.39 & 1.39 & 1.34 & 1.41 \\
\hline $\mathrm{P}_{2} \mathrm{O}_{5} \ldots \ldots$ & .26 & .20 & .082 & .072 & .075 & .078 & .06 & .07 & .12 & .094 \\
\hline $\mathrm{MnO} \ldots$ & .20 & .24 & .15 & .16 & .19 & .10 & .07 & .04 & .052 & .042 \\
\hline Total $\ldots$ & 91.7 & 97.5 & 94.6 & 96.7 & 95.7 & 95.6 & 93.2 & 94.2 & 88.9 & 96.1 \\
\hline $\mathrm{Fe}_{2} \mathrm{O}_{3}+\mathrm{Al}_{2} \mathrm{O}_{3} / \mathrm{SiO}_{2}$ & 13.9 & 14.0 & 21.2 & 22.4 & 24.5 & 28.4 & 27.4 & 29.3 & 31.5 & 27.3 \\
\hline
\end{tabular}


Table 9D. Analyses of extractable Fe, $\mathrm{Al}$, and $\mathrm{Mn}$, oxalates, ratio clay, and bulk density of soil horizons at site $8,45 \mathrm{~m}$ terrace [Sampled as: fine-loamy, over clayey, mixed, thermic Typic Paleudult; TR means trace; -- means not analyzed; * means estimated]

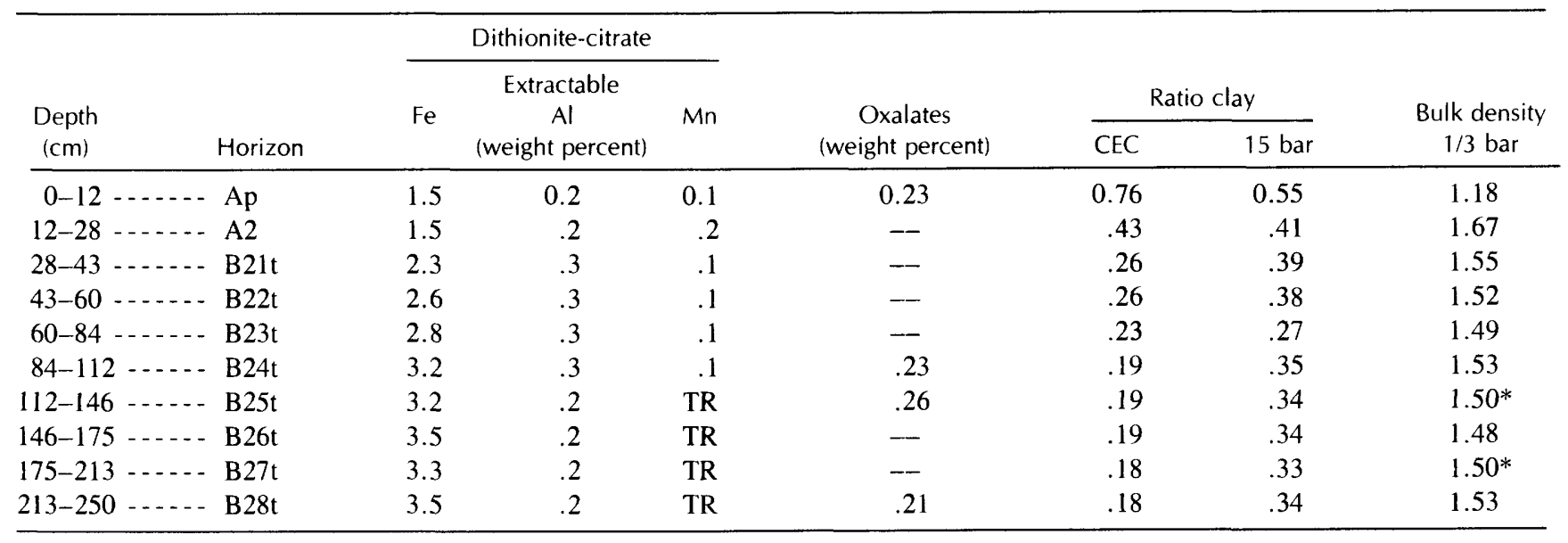

Table $9 E$. Analyses of extractable bases, cation exchange capacity (CEC), and $\mathrm{pH}$ for soil horizons at site $8,45 \mathrm{~m}$ terrace [-- means not detected]

\begin{tabular}{|c|c|c|c|c|c|c|c|c|c|}
\hline \multirow{2}{*}{$\begin{array}{c}\text { Depth } \\
(\mathrm{cm})\end{array}$} & \multirow{2}{*}{ Horizon } & \multirow{2}{*}{\multicolumn{3}{|c|}{$\mathrm{NH}_{4} \mathrm{OAC}$ extractable bases }} & \multirow{2}{*}{ Acidity } & & & \multicolumn{2}{|c|}{$\mathrm{pH}$} \\
\hline & & & & & & \multicolumn{2}{|c|}{ CEC } & $\begin{array}{c}\mathrm{CaCl}_{2} \\
(.01 \mathrm{M}) \\
1: 2\end{array}$ & $\begin{array}{l}\mathrm{H}_{2} \mathrm{O} \\
1: 1\end{array}$ \\
\hline $0-12 \ldots$ & Ap & 16.5 & 2.4 & 1.4 & - & 15.0 & -- & 7.2 & 7.5 \\
\hline $12-28 \ldots \ldots$ & A2 & 4.7 & 1.4 & 0.6 & 6.0 & 12.7 & 8.6 & 5.6 & 6.1 \\
\hline $60-84 \ldots \ldots$ & B23t & 5.5 & 1.1 & .4 & 5.3 & 12.3 & 8.6 & 5.7 & 6.1 \\
\hline $84-112 \ldots$ & $\mathrm{B} 24 \mathrm{t}$ & 5.7 & 1.1 & .2 & 5.4 & 12.4 & 8.5 & 5.9 & 6.3 \\
\hline $112-146 \ldots$ & $\mathrm{B} 25 \mathrm{t}$ & 5.6 & 1.0 & .2 & 5.1 & 11.9 & 8.2 & 6.1 & 6.5 \\
\hline $146-175 \cdots$ & B26t & 6.1 & 1.2 & .2 & 5.2 & 12.7 & 8.9 & 6.2 & 6.4 \\
\hline $175-213 \ldots$ & $B 27 t$ & 5.6 & 1.5 & .2 & 5.0 & 12.3 & 8.4 & 6.1 & 6.5 \\
\hline
\end{tabular}







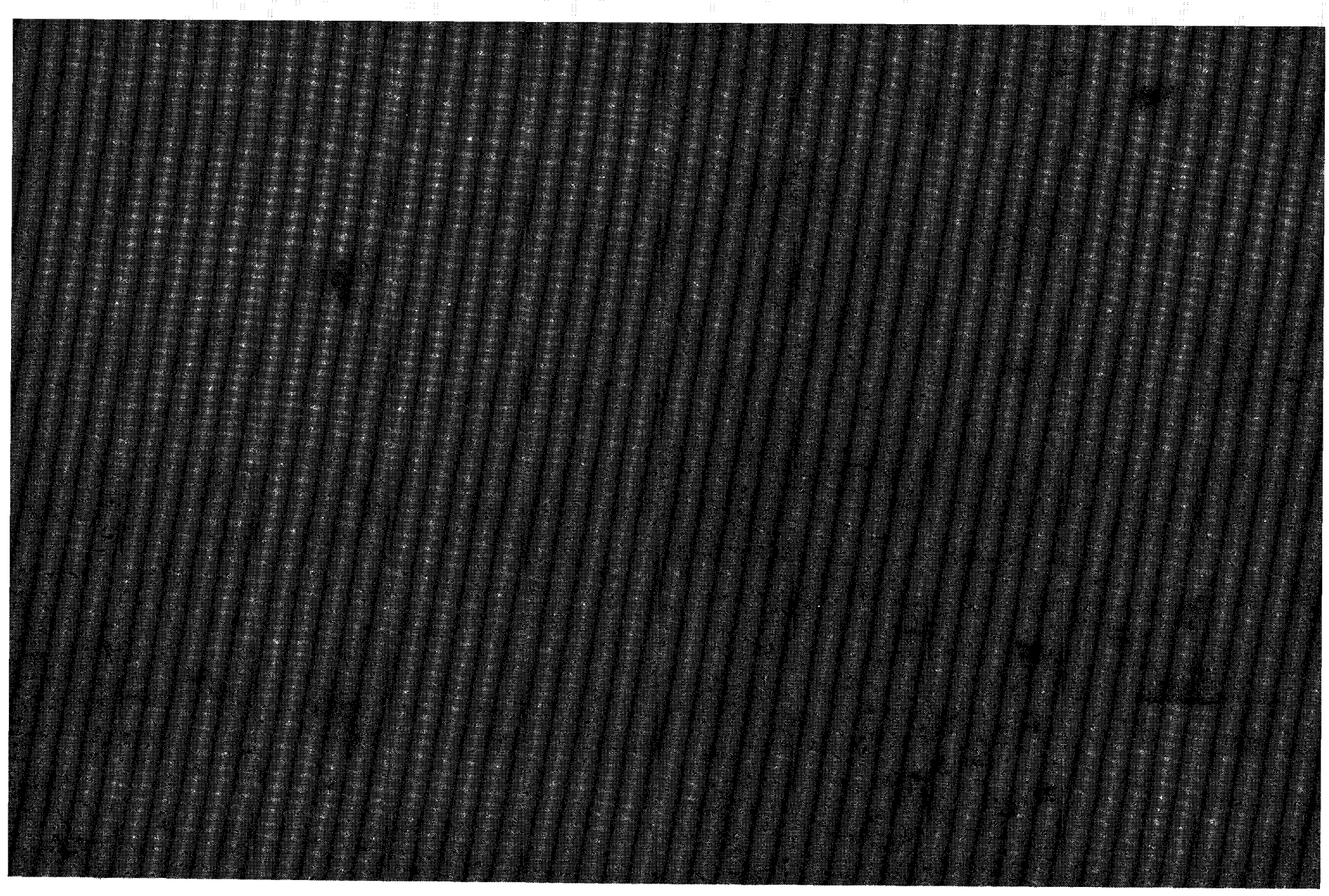

